\title{
Adsorption of Pure Methane, Nitrogen, and Carbon Dioxide and Their Mixtures on San Juan Basin Coal
}

\author{
Topical Report
}

January, 2001 - March, 2002

\author{
K. A. M. Gasem \\ R. L. Robinson, Jr. \\ S.R. Reeves
}

Contract No. DE-FC26-00NT40924

May, 2002

Oklahoma State University

School of Chemical Engineering

Stillwater, Oklahoma 74078-0537

and

Advanced Resources International

9801 Westheimer, Suite 805

Houston, TX 77042
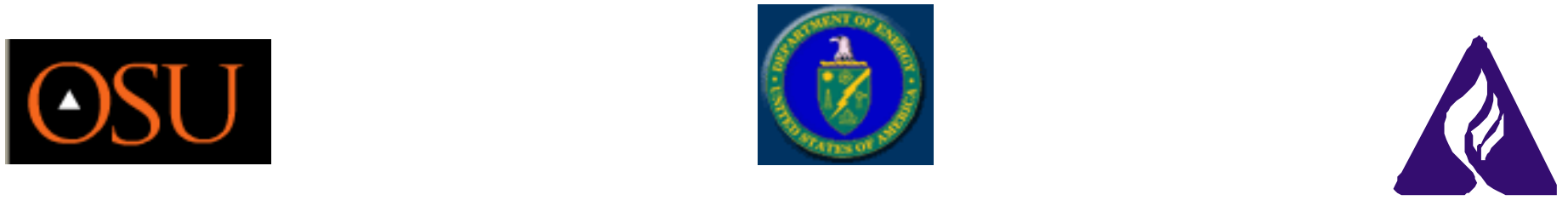


\section{U.S. Department of Energy Disclaimer}

This report was prepared as an account of work sponsored by an agency of the United States Government. Neither the United Sates Government nor any agency thereof, nor any of their employees, makes any warranty, express or implied, or assumes any legal liability or responsibility for the accuracy, completeness, or usefulness of any information, apparatus, product, or process disclosed, or represents that its use would not infringe privately owned rights. Reference herein to any specific commercial product, process, or service by trade name, trademark, manufacturer, or otherwise does not necessarily constitute or imply its endorsement, recommendation, or favoring by the United States Government or any agency thereof. The views and opinions of authors expressed herein do not necessarily state or reflect those of the United Sates Government or any agency thereof.

\section{Oklahoma State University Disclaimer}

The Principal Investigators agreed to undertake this research on a best effort basis. Neither Oklahoma State University and the Principal Investigators, nor any of their employees, make any warranty, express or implied, or assumes any legal liability or responsibility for the accuracy, completeness, or usefulness of any information, apparatus, product, or process disclosed or represents that its use would not infringe privately owned rights.

\section{Advanced Resources International Disclaimer}

The material in this Report is intended for general information only. Any use of this material in relation to any specific application should be based on independent examination and verification of its unrestricted applicability for such use and on a determination of suitability for the application by professionally qualified personnel. No license under any Advanced Resources International, Inc., patents or other proprietary interest is implied by the publication of this Report. Those making use of or relying upon the material assume all risks and liability arising from such use or reliance. 


\section{Abstract}

The major objectives of this project were to (a) measure the adsorption behavior of pure methane, nitrogen, $\mathrm{CO}_{2}$ and their binary and ternary mixtures on wet Tiffany coal at $130^{\circ} \mathrm{F}$ and pressures to 2000 psia; (b) correlate the equilibrium adsorption isotherm data using the extended Langmuir model, the Langmuir model, the loading ratio correlation and the Zhou-Gasem-Robinson equation of state; and (c) establish sorption-time estimates for the pure components. Specific accomplishments are summarized below regarding the complementary tasks involving experimental work and data correlation.

- Representative coal samples from BP Amoco Tiffany Injection Wells \#1 and \#10 were prepared, as requested. The equilibrium moisture content and particle size distribution of each coal sample were determined. Compositional coal analyses for both samples were performed by Huffman Laboratories, Inc.

- Pure gas adsorption for methane on wet Tiffany coal samples from Injection Wells \#1 and \#10 was measured separately at $130^{\circ} \mathrm{F}(327.6 \mathrm{~K})$ and pressures to 2000 psia (13.7 MPa). The average expected uncertainty in these data is about $3 \%$ (9 SCF/ton). Our measurements indicate that the adsorption isotherms of the two coal samples exhibit similar Langmuir-type behavior. For the samples from the two wells, a maximum variation of about $5 \%$ in the amount adsorbed is observed at 2000 psia.

- Gas adsorption isotherms were measured for pure methane, nitrogen and $\mathrm{CO}_{2}$ on a wet, mixed Tiffany coal sample. The coal sample was an equalmass mixture of coals from Well \#1 and Well \#10. The adsorption measurements were conducted at $130^{\circ} \mathrm{F}$ at pressures to 2000 psia. The adsorption isotherms have average expected experimental uncertainties of $3 \%$ (9 SCF/ton), $6 \%$ (8 SCF/ton), and 7\% (62 SCF/ton) for methane, nitrogen, and $\mathrm{CO}_{2}$, respectively.

- Adsorption isotherms were measured for methane/nitrogen, methane/ $\mathrm{CO}_{2}$ and nitrogen $/ \mathrm{CO}_{2}$ binary mixtures on wet, mixed Tiffany coal at $130^{\circ} \mathrm{F}$ and pressures to 2000 psia. These measurements were conducted for a single molar feed composition for each mixture. The expected uncertainties in the amount adsorbed for these binary mixtures vary with pressure and composition. In general, average uncertainties are about 5\% (19 SCF/ton) for the total adsorption; however, the expected uncertainties in the amount of individual-component adsorption are significantly higher for the less-adsorbed gas at lower molar feed concentrations (e.g., nitrogen in the 20/80 nitrogen $/ \mathrm{CO}_{2}$ system).

- Adsorption isotherms were measured for a single methane/nitrogen/ $/ \mathrm{CO}_{2}$ ternary mixture on wet, mixed Tiffany coal at $130^{\circ} \mathrm{F}$ and pressures to 2000 psia. The nominal molar feed composition was 10/40/50. The average expected uncertainty for the total adsorption and $\mathrm{CO}_{2}$ adsorption is about $5 \%$ 
(16 SCF/ton). However, the low adsorption of nitrogen and methane in this ternary yield average experimental uncertainties of $14 \%$ (9 SCF/ton) and $27 \%$ (9 SCF/ton), respectively.

- Limited binary and ternary gas-phase compressibility factor measurements at $130^{\circ} \mathrm{F}$ and pressures to 2000 psia involving methane, nitrogen, and $\mathrm{CO}_{2}$ were conducted to facilitate reduction of our ternary adsorption data. These newly acquired data (and available data from the literature) were used to improve the Benedict-Webb-Rubin (BWR) equation-of-state (EOS) compressibility factor predictions, which are used in material balance calculations for the adsorption measurements. In general, the optimized BWR EOS represents the experimental compressibility factor data within $0.5 \%$ AAD.

- The Langmuir/loading ratio correlation (LRC) and the Zhou-Gasem-Robinson (ZGR) two-dimensional EOS were used to analyze the newly acquired adsorption data. Model parameters were obtained for the systems studied.

- The LRC and ZGR EOS were used to correlate the adsorption data for methane, nitrogen, and $\mathrm{CO}_{2}$ and their mixtures on wet Tiffany coal. The model parameters were determined by minimizing the sum of squares of weighted errors in the calculated amounts of gas adsorbed. The results demonstrate the ability of the LRC and ZGR EOS to represent the total pure, binary and ternary systems within their expected experimental uncertainties. Specifically, representations with average absolute percentage errors (AAD) of $1-3 \%$ (2-15 SCF/ton), $1-8 \%$ (1-25 SCF/ton), and $2-10 \%$ (7-37 SCF/ton) were obtained for the pure, total binary, and total ternary adsorption isotherms, respectively. However, the quality of fit for the individualcomponent adsorption varies significantly, ranging from $3 \%$ for the moreadsorbed methane or $\mathrm{CO}_{2}$ to $32 \%$ for the less-adsorbed nitrogen.

- The LRC and ZGR EOS are capable of predicting binary adsorption isotherms based solely on pure-fluid adsorption parameters within twice their experimental uncertainties (1-50 \%AAD, 5-40 SCF/ton). In comparison, the ternary predictions based on pure-fluid parameters yield three times the experimental uncertainties (4-56 \%AAD, 2-60 SCF/ton). The quality of the model predictions indicate that although the two models are capable of predicting total adsorption isotherms adequately, they predict individualcomponent adsorption in mixtures poorly, especially when dealing with the less-adsorbed component of the mixture.

- Sorption-time estimates for pure methane, nitrogen, and $\mathrm{CO}_{2}$ were represented with average errors of about $8 \%$. 


\section{TABLE OF CONTENTS}

Page

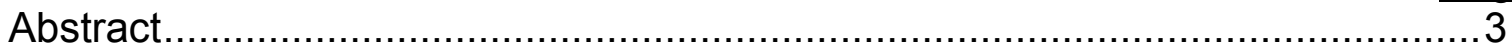

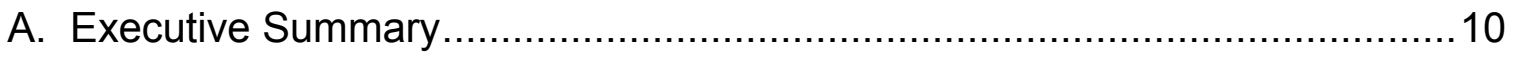

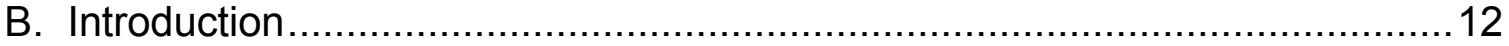

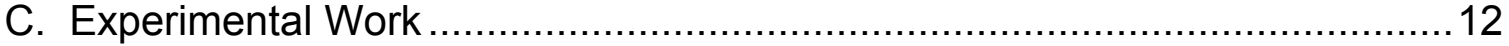

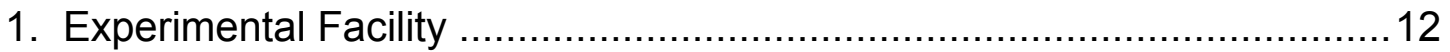

2. Experimental Methods and Procedures............................................12

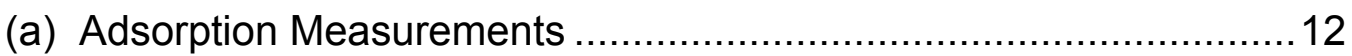

(b) Determination of Coal Particle Size Distribution.............................17

(c ) Determination of Coal Moisture Content ....................................18

(d) Sorption-Time Measurements for Pure Gases............................. 18

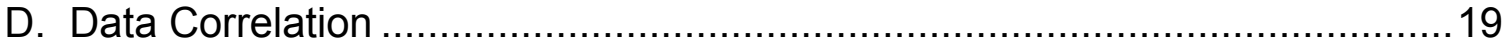

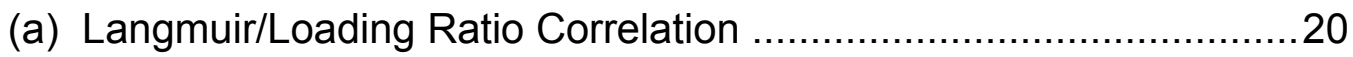

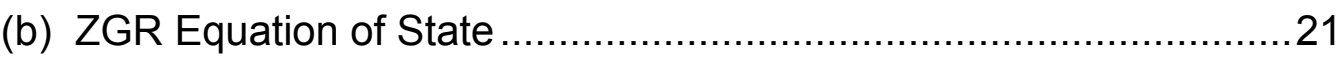

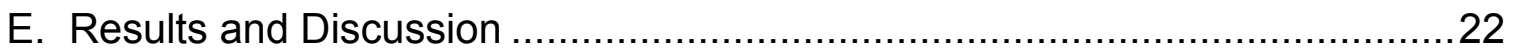

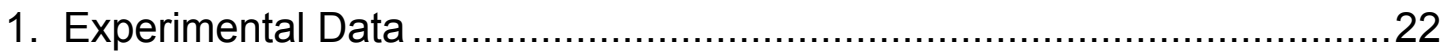

(a) Comparison of Tiffany Coal Samples.........................................22

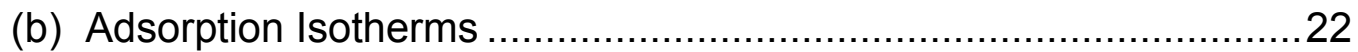

(c ) Sorption-Time Estimates for Pure Gases ..................................25

2. Data Correlation and Model Evaluation ……......................................26

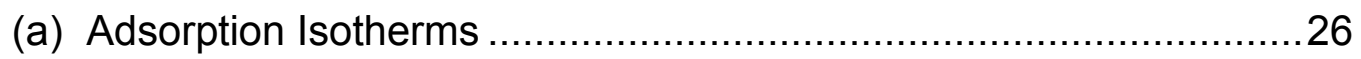

(b) Sorption-Time Estimates for Pure Gases ....................................29

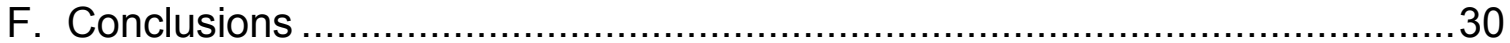

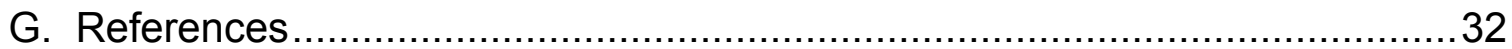

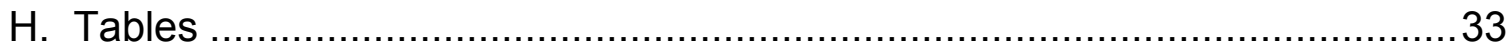

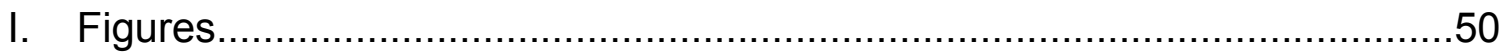




\section{List of Tables}

Page

Table 1. Compositional Analyses of Tiffany Coal Samples* 33

Table 2. Tiffany Coal Particle Size Distribution .............................................................. 33

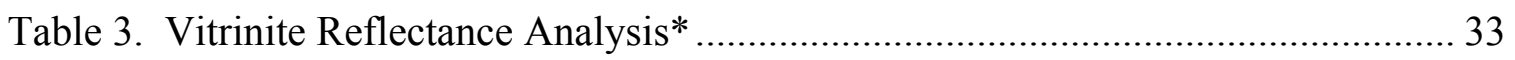

Table 4. Pure Methane Adsorption on Wet Tiffany Well \#1 Coal at $130^{\circ} \mathrm{F}: 5.6 \%$ Moisture Content ............................................................................... 34

Table 5. Pure Methane Adsorption on Wet Tiffany Well \#10 Coal at $130^{\circ} \mathrm{F}: 16.5 \%$

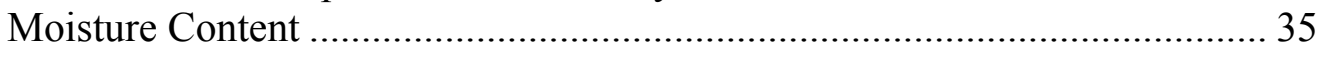

Table 6. Pure Methane Adsorption on Wet Tiffany Mixed Coal Sample at $130{ }^{\circ} \mathrm{F}$ : 11.7\% Moisture Content .......................................................................... 36

Table 7. Pure Nitrogen Adsorption on Wet Tiffany Mixed Coal Sample at $130^{\circ} \mathrm{F}$ : 11.7\% Moisture Content .......................................................................... 36

Table 8. Pure $\mathrm{CO}_{2}$ Adsorption on Wet Tiffany Mixed Coal Sample at $130^{\circ} \mathrm{F}: 11.7 \%$ Moisture Content ……………………...................................................... 37

Table 9. Methane/Nitrogen Adsorption on a Wet Tiffany Mixed Coal Sample at $130^{\circ} \mathrm{F}:$ 10.5\% Moisture Content ..................................................................... 38

Table 10. Methane $/ \mathrm{CO}_{2}$ Adsorption on a Wet Tiffany Mixed Coal Sample at $130{ }^{\circ} \mathrm{F}$ : $11.4 \%$ Moisture Content

Table 11. Nitrogen $/ \mathrm{CO}_{2}$ Adsorption on a Wet Tiffany Mixed Coal Sample at $130{ }^{\circ} \mathrm{F}$ : $10.4 \%$ Moisture Content

Table 12. Adsorption of a 10/40/50 Mole $\%$ Methane/Nitrogen $/ \mathrm{CO}_{2}$ Feed Mixture on a Wet Tiffany Mixed Coal Sample at $130{ }^{\circ} \mathrm{F}: 10.5 \%$ Moisture Content ........ 41

Table 12. (Continued) Adsorption of a 10/40/50 Mole $\%$ Methane/Nitrogen $/ \mathrm{CO}_{2}$ Feed Mixture on a Wet Tiffany Mixed Coal Sample at $130^{\circ} \mathrm{F}: 10.5 \%$ Moisture Content

Table 13. Desorption Time for Methane on Wet Tiffany Well \#1 Coal Sample at $130^{\circ} \mathrm{F}$

Table 14. Desorption Time for Methane on Wet Tiffany Well \#10 Coal Sample at $130{ }^{\circ} \mathrm{F}$

Table 15. Desorption Time for Nitrogen on Wet Tiffany Mixed Coal Sample at $130^{\circ} \mathrm{F}$ 43

Table 16. Adsorption Time for $\mathrm{CO}_{2}$ on Wet Tiffany Mixed Coal Sample at $130^{\circ} \mathrm{F}$........ 44

Table 17. Langmuir Model Representation of Adsorption on Wet Tiffany Coals at $130^{\circ} \mathrm{F}$

Table 18. LRC Model Representation of Adsorption on Wet Tiffany Coals at $130^{\circ} \mathrm{F} . . .44$ 
Table 19. LRC Model Representation of Adsorption on Wet, Mixed Tiffany Coals at

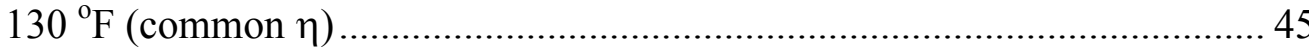

Table 20. ZGR Equation-of-State Representation of Adsorption on Wet, Mixed Tiffany Coals at $130{ }^{\circ} \mathrm{F}$ 45

Table 21. LRC Model Representation of Binary Adsorption on Wet Tiffany Coals at $130{ }^{\circ} \mathrm{F}$ 45

Table 22. LRC Model Predictions of Binary Adsorption on Wet Tiffany Coals at $130{ }^{\circ} \mathrm{F}$ 46

Table 23. LRC Model Representation of Ternary Adsorption on Wet Tiffany Coals at $130{ }^{\circ} \mathrm{F}$ 46

Table 24. LRC Model Predictions of Ternary Adsorption on Wet Tiffany Coals at $130{ }^{\circ} \mathrm{F}$ 47

Table 25. ZGR EOS Representation of Mixtures on Tiffany Mixed Coal at $130{ }^{\circ} \mathrm{F}$...... 48

Table 26. Sorption Fractional Uptake Correlation............................................................. 49

Table 27. Sorption-Time Estimates on Wet Tiffany Coal Samples at $130^{\circ} \mathrm{F}$ for $63 \%$ Desorption 


\section{List of Figures}

$\underline{\text { Page }}$

Figure 1: Schematic Diagram of Adsorption Apparatus .................................51

Figure 2: Tiffany Well \#1 Coal Particle Size Distribution .................................52

Figure 3: Tiffany Well \#10 Coal Particle Size Distribution ................................53

Figure 4: Tiffany Well \#1 and Well \#10 Coal Particle Size Distributions ............ 54

Figure 5: Pure Methane Absolute Adsorption on Tiffany Coal Samples

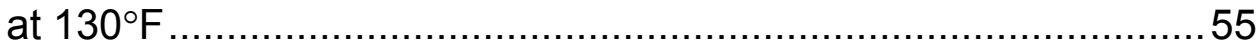

Figure 6: Pure Gas Gibbs Adsorption on Tiffany Coals at $130^{\circ} \mathrm{F} \ldots \ldots \ldots \ldots \ldots \ldots \ldots . . . . . . . . .56$

Figure 7: Pure Gas Absolute Adsorption on Tiffany Coals at $130^{\circ} \mathrm{F}$................. 57

Figure 8: Pure Nitrogen Absolute Adsorption on Tiffany Mixed Coal

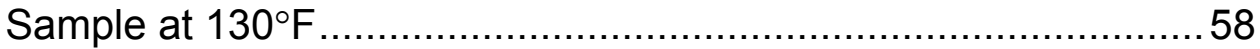

Figure 9: Pure $\mathrm{CO}_{2}$ Absolute Adsorption on Tiffany Mixed Coal Sample

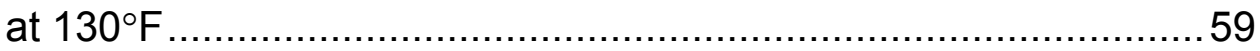

Figure 10: $\mathrm{CO}_{2}$ Absolute Adsorption on Tiffany Mixed Coal Sample Using Different Adsorbed-Phase Densities.

Figure 11: Gibbs Adsorption of a 50/50 Mole \% Methane/Nitrogen Feed

Mixture on a Wet Tiffany Mixed Coal Sample at $130^{\circ} \mathrm{F}$

Figure 12: Absolute Adsorption for 50/50 Mole \% Methane/Nitrogen Feed Mixture on a Wet Tiffany Mixed Coal Sample at $130^{\circ} \mathrm{F}$

Figure 13: Gibbs Adsorption of a 40/60 Mole \% Methane/ $/ \mathrm{CO}_{2}$ Feed

Mixture on a Wet Tiffany Mixed Coal Sample at $130^{\circ} \mathrm{F}$

Figure 14: Absolute Adsorption for 40/60 Mole \% Methane/ $\mathrm{CO}_{2}$ Feed Mixture on a Wet Tiffany Mixed Coal Sample at $130^{\circ} \mathrm{F}$

Figure 15: Gibbs Adsorption of a 20/80 Mole $\%$ Nitrogen $/ \mathrm{CO}_{2}$ Feed Mixture on a Wet Tiffany Mixed Coal Sample at $130^{\circ} \mathrm{F}$

Figure 16: Absolute Adsorption for 20/80 Mole \% Nitrogen/ $\mathrm{CO}_{2}$ Feed Mixture on a Wet Tiffany Mixed Coal Sample at $130^{\circ} \mathrm{F}$ 66

Figure 17: Gibbs Adsorption of a 10/40/50 Mole \% Methane/Nitrogen/ $\mathrm{CO}_{2}$ Feed Mixture on a Wet Tiffany Mixed Coal Sample at $130^{\circ} \mathrm{F}$

Figure 18: Absolute Adsorption for 10/40/50 Mole \% Methane/Nitrogen/ $\mathrm{CO}_{2}$ Feed on a Wet Tiffany Mixed Coal Sample at $130^{\circ} \mathrm{F}$

Figure 19: Fractional Uptake of Methane Desorption on Tiffany Well \#1 Coal at $130^{\circ} \mathrm{F}$ 
Figure 20: Fractional Uptake of Methane Desorption on Tiffany Well \#10 Coal at $130^{\circ} \mathrm{F}$

Figure 21: Fractional Uptake of Nitrogen on Tiffany Mixed Coal at $130^{\circ} \mathrm{F}$

Figure 22: Fractional Uptake of $\mathrm{CO}_{2}$ Adsorption on Tiffany Mixed Coal at $130^{\circ} \mathrm{F}$

Figure 23: Model Predictions of Absolute Adsorption for 50/50 Mole \% Methane/Nitrogen Feed Mixture on a Wet Tiffany Mixed Coal Sample at $130^{\circ} \mathrm{F}$

Figure 24: Model Predictions on Absolute for $40 / 60$ Mole $\%$ Methane/ $\mathrm{CO}_{2}$ Feed Mixture on a Wet Tiffany Mixed Coal Sample at $130^{\circ} \mathrm{F}$ 74

Figure 25: Model Predictions of Absolute Adsorption for 20/80 Mole \% Nitrogen $/ \mathrm{CO}_{2}$ Feed Mixture on a Wet Tiffany Mixed Coal Sample at $130^{\circ} \mathrm{F}$..... 75

Figure 26: Model Predictions of Absolute Adsorption for 10/40/50 Mole \% Methane/Nitrogen $/ \mathrm{CO}_{2}$ Feed on a Wet Tiffany Mixed Coal Sample at $130^{\circ} \mathrm{F}$......

Figure 27: Desorption Curve for Methane on Tiffany Well \#1 Coal at $130^{\circ} \mathrm{F}$

Figure 28: Desorption Curve for Methane on Tiffany Well \#10 Coal at $130^{\circ} \mathrm{F}$ 78

Figure 29: Desorption Curve for Nitrogen on Tiffany Mixed Coal at $130^{\circ} \mathrm{F}$ 79

Figure 30: Adsorption Curve for $\mathrm{CO}_{2}$ on Tiffany Mixed Coal at $130^{\circ} \mathrm{F}$ 80

Figure 31: Liberated Gas from Tiffany Coal Samples: 2000 to 14.7 psia. 


\section{A. Executive Summary}

The major objectives of this project were to (a) measure the adsorption behavior of pure methane, nitrogen, $\mathrm{CO}_{2}$ and their binary and ternary mixtures on wet Tiffany coal at $130^{\circ} \mathrm{F}$ and pressures to 2000 psia; (b) correlate the equilibrium adsorption isotherm data using the extended Langmuir model, the Langmuir model, the loading ratio correlation and the Zhou-Gasem-Robinson equation of state; and (c) establish sorption-time estimates for the pure components. Specific accomplishments are summarized below regarding the complementary tasks involving experimental work and data correlation.

\section{Experimental Work}

- Representative coal samples from BP Amoco Tiffany Injection Wells \#1 and \#10 were prepared, as requested. The equilibrium moisture content and particle size distribution of each coal sample were determined. Compositional coal analyses for both samples were performed by Huffman Laboratories, Inc.

- Pure gas adsorption for methane on wet Tiffany coal samples from Injection Wells \#1 and \#10 was measured separately at $130^{\circ} \mathrm{F}(327.6 \mathrm{~K})$ and pressures to 2000 psia $(13.7 \mathrm{MPa})$. The average expected uncertainty in these data is about $3 \%$ (9 SCF/ton). Our measurements indicate that the adsorption isotherms of the two coal samples exhibit similar Langmuir-type behavior. For the samples from the two wells, a maximum variation of about $5 \%$ in the amount adsorbed is observed at 2000 psia.

- Gas adsorption isotherms were measured for pure methane, nitrogen and $\mathrm{CO}_{2}$ on a wet, mixed Tiffany coal sample. The coal sample was an equalmass mixture of coals from Well \#1 and Well \#10. The adsorption measurements were conducted at $130^{\circ} \mathrm{F}$ at pressures to 2000 psia. The adsorption isotherms have average expected experimental uncertainties of $3 \%$ (9 SCF/ton), $6 \%$ (8 SCF/ton), and 7\% (62 SCF/ton) for methane, nitrogen, and $\mathrm{CO}_{2}$, respectively.

- Adsorption isotherms were measured for methane/nitrogen, methane/ $\mathrm{CO}_{2}$ and nitrogen $/ \mathrm{CO}_{2}$ binary mixtures on wet, mixed Tiffany coal at $130^{\circ} \mathrm{F}$ and pressures to 2000 psia. These measurements were conducted for a single molar feed composition for each mixture. The expected uncertainties in the amount adsorbed for these binary mixtures vary with pressure and composition. In general, average uncertainties are about 5\% (19 SCF/ton) for the total adsorption; however, the expected uncertainties in the amount of individual-component adsorption are significantly higher for the less-adsorbed gas at lower molar feed concentrations (e.g., nitrogen in the 20/80 nitrogen $/ \mathrm{CO}_{2}$ system).

- Adsorption isotherms were measured for a single methane/nitrogen $/ \mathrm{CO}_{2}$ ternary mixture on wet, mixed Tiffany coal at $130^{\circ} \mathrm{F}$ and pressures to 2000 
psia. The nominal molar feed composition was 10/40/50. The average expected uncertainty for the total adsorption and $\mathrm{CO}_{2}$ adsorption is about $5 \%$ (16 SCF/ton). However, the low adsorption of nitrogen and methane in this ternary yield average experimental uncertainties of $14 \%$ (9 SCF/ton) and $27 \%$ (9 SCF/ton), respectively.

- Limited binary and ternary gas-phase compressibility factor measurements at $130^{\circ} \mathrm{F}$ and pressures to 2000 psia involving methane, nitrogen, and $\mathrm{CO}_{2}$ were conducted to facilitate reduction of our ternary adsorption data. These newly acquired data (and available data from the literature) were used to improve the Benedict-Webb-Rubin (BWR) equation-of-state (EOS) compressibility factor predictions, which are used in material balance calculations for the adsorption measurements. In general, the optimized BWR EOS represents the experimental compressibility factor data within $0.5 \%$ AAD.

\section{Data Correlation}

- The Langmuir/loading ratio correlation (LRC) and the Zhou-Gasem-Robinson (ZGR) two-dimensional EOS were used to analyze the newly acquired adsorption data. Model parameters were obtained for the systems studied.

- The LRC and ZGR EOS were used to correlate the adsorption data for methane, nitrogen, and $\mathrm{CO}_{2}$ and their mixtures on wet Tiffany coal. The model parameters were determined by minimizing the sum of squares of weighted errors in the calculated amounts of gas adsorbed. The results demonstrate the ability of the LRC and ZGR EOS to represent the total pure, binary and ternary systems within their expected experimental uncertainties. Specifically, representations with average absolute percentage errors (AAD) of $1-3 \%$ (2-15 SCF/ton), $1-8 \%$ (1-25 SCF/ton), and 2-10\% (7-37 SCF/ton) were obtained for the pure, total binary, and total ternary adsorption isotherms, respectively. However, the quality of fit for the individualcomponent adsorption varies significantly, ranging from 3\% for the moreadsorbed methane or $\mathrm{CO}_{2}$ to $32 \%$ for the less-adsorbed nitrogen.

- The LRC and ZGR EOS are capable of predicting binary adsorption isotherms based solely on pure-fluid adsorption parameters within twice their experimental uncertainties (1-50 \%AAD, 5-40 SCF/ton). In comparison, the ternary predictions based on pure-fluid parameters yield three times the experimental uncertainties (4-56 \%AAD, 2-60 SCF/ton). The quality of the model predictions indicate that although the two models are capable of predicting total adsorption isotherms adequately, they predict individualcomponent adsorption in mixtures poorly, especially when dealing with the less-adsorbed component of the mixture.

- Sorption-time estimates for pure methane, nitrogen, and $\mathrm{CO}_{2}$ were represented with average errors of about $8 \%$. 


\section{B. Introduction}

The specific objectives of the adsorption measurements and correlations for BP Amoco Tiffany coal were to:

- Prepare representative coal samples from Injection Well \#1 and Injection Well \#10.

- Determine (a) equilibrium moisture content, (b) particle size distribution, (c) compositional analyses, and (d) vitrinite reflectance analysis for each coal sample.

- Measure the adsorption behaviors of pure methane, nitrogen, $\mathrm{CO}_{2}$ and their binary and ternary mixtures on a Tiffany equal-mass, mixed-coal sample from Injector Wells \#1 and \#10 at $130^{\circ} \mathrm{F}$ and pressures to 2000 psia. The nominal molar feed compositions for the methane/nitrogen, methane/ $\mathrm{CO}_{2}$, and nitrogen/ $\mathrm{CO}_{2}$ binary mixtures were specified at 50/50, 40/60, and 20/80, respectively. The nominal molar feed composition for the methane/nitrogen/ $\mathrm{CO}_{2}$ ternary mixture was $10 / 40 / 50$.

- Correlate the equilibrium adsorption isotherm data using the extended Langmuir model, the Langmuir model, the loading ratio correlation and the Zhou-Gasem-Robinson equation of state.

- Establish sorption-time estimates for the pure components.

\section{Experimental Work}

\section{Experimental Facility}

The experimental apparatus was developed in previous work for Amoco Corporation and the Oklahoma Center for the Advancement of Science and Technology. As a precursor to the present data acquisition, the apparatus was thoroughly re-tested and revised as necessary. The equipment is described in detail elsewhere $[1,2]$.

Recently, we enhanced our experimental facility to include the ability to measure adsorption kinetics for systems encountered in coalbed methane production and sequestration of $\mathrm{CO}_{2}$. Brief descriptions of experimental methods and procedures are given in the following section.

\section{Experimental Methods and Procedures}

\section{(a) Adsorption Measurements}

Our experimental technique employs a mass balance method, utilizing volumetric accounting principles. The experimental apparatus, shown schematically in 
Figure 1, has been used successfully in previous measurements [1, 2]. Brief descriptions of the experimental apparatus and procedures follow.

The entire apparatus (both Pump and Cell sections) is maintained in a constant temperature air bath. The equilibrium cell (EC, Figure 1) is filled with the coal to be studied, and the cell is placed under vacuum prior to gas injection. The void (gas) volume, $V_{\text {void, }}$ in the equilibrium cell is then determined by injecting a known quantity of helium from a calibrated injection pump. Since helium is not adsorbed, the void volume can be determined from measured values of the temperature, pressure and amount of helium injected into the cell. The void volume equations are

$$
\begin{aligned}
& \mathrm{V}_{\text {void }}=\mathrm{n}_{\mathrm{He}}\left(\mathrm{Z}_{\mathrm{He}} \mathrm{RT} / \mathrm{P}\right)_{\text {cell }} \\
& \mathrm{n}_{\mathrm{He}}=\left(\mathrm{PV} / \mathrm{Z}_{\mathrm{He}} \mathrm{RT}\right)_{\text {pump }}(2)
\end{aligned}
$$

In these equations, $\mathrm{n}_{\mathrm{He}}$ is the number of moles of helium injected into the cell, $\mathrm{V}$ is the volume of gas injected from the pump, $\mathrm{Z}_{\mathrm{He}}$ is the compressibility factor of helium, $R$ is the universal gas constant, $T$ is the temperature, $P$ is the pressure, and the subscripts "cell" and "pump" refer to conditions in the cell and pump sections of the apparatus, respectively.

The amount of gas (methane, for example) adsorbed at a given pressure can be calculated based on the preliminary calibrations done above. First, a given quantity of methane, $n_{\text {inj }}$, is injected into the cell. This amount is determined by an equation analogous to Equation 2, above. A magnetic recirculating pump is used to circulate methane over the adsorbent until equilibrium is reached, where no further methane is adsorbed. The amount of unadsorbed methane, $n_{\text {unads }}$, is then determined based on the fact that any unadsorbed methane will remain in the void volume (determined from the helium calibration). The expression for this quantity is

$$
\mathrm{n}_{\text {unads }}=\left(P V_{\text {void }} / Z_{\text {methane }} R T\right)_{\text {cell }}
$$

where the pressure $P$ is measured after equilibrium is reached in the cell. In addition, we estimate the amount of gas dissolved in water, $\mathrm{n}_{\text {dis, }}$ using correlations for gas solubility [2]. The amount of adsorbed methane, $n_{a d s}$, is then calculated by difference as

$$
\mathrm{n}_{\text {ads }}=\mathrm{n}_{\text {inj }}-\mathrm{n}_{\text {unads }}-\mathrm{n}_{\text {dis }}
$$

These steps are repeated at sequentially higher pressures to yield a complete adsorption isotherm.

In mixture studies, a gas mixture of known composition is injected, so the total amount of each gas fed into the cell is known. The amount of unadsorbed gas at each pressure is calculated by Equation 3 with $Z_{\text {methane }}$ replaced by $Z_{\text {mix }}$, the gas 
mixture compressibility factor. The composition of the gas mixture in the void volume is determined by chromatographic analysis using a microliter-size sample captured in a sampling valve (SV1). This permits the total amount of unadsorbed gas to be apportioned among the various components according to their mole fractions in the gas. Equation 4 can be then applied to each component in the gas mixture. For methane/nitrogen/ $\mathrm{CO}_{2}$ mixtures, the mixture $Z$ factors $\left(Z_{\text {mix }}\right)$ are determined accurately from the BWR EOS, as described below.

The estimated uncertainties in each of the experimentally measured quantities are as follows: temperature $0.2^{\circ} \mathrm{F}$, pressure $1.0 \mathrm{psia}$, injected gas volumes 0.02 cc, bulk gas-phase composition 0.001 in mole fraction. The expected uncertainties in the amount adsorbed are estimated using error propagation in all the measured variables and confirmed by replicate runs.

\section{Compressibility Factors}

As indicated by Equations 1-3, accurate gas-phase compressibility $(Z)$ factors are required for methane, nitrogen and carbon dioxide and their mixtures to properly analyze our experimental adsorption data. The compressibility factors for pure methane, nitrogen and $\mathrm{CO}_{2}$ were determined from highly accurate equations of state [3-5]. However, a careful evaluation of the current literature led us to conclude that an adequate predictive capability for the mixture $Z$ factors does not exist. Therefore, we elected to develop such a capability using the BenedictWebb-Rubin (BWR) equation of state.

Specifically, we used available pure-fluid and binary mixture data to refit the BWR equation and improve its accuracy significantly; in general, the new BWR EOS parameters yield deviations in the $Z$ factor within $0.2 \%$. This allowed us to address our compressibility factor needs for binary adsorption mixtures.

To facilitate our ternary adsorption measurements, we conducted a limited number of binary and ternary compressibility factor measurements involving methane, nitrogen, and $\mathrm{CO}_{2}$ at $130^{\circ} \mathrm{F}$ and pressures to 2000 psia. These newly acquired data and available data from the literature were used to improve the BWR EOS compressibility factor predictions. In general, the optimized BWR EOS represents the compressibility factor data within 0.5\% AAD [11].

\section{Relationship between Gibbs and Absolute Adsorption}

By definition, Gibbs adsorption considers the gas-phase volume as the sum of the gas $\left(\mathrm{V}_{\text {gas }}\right)$ and adsorbed phase $\left(\mathrm{V}_{\text {ads }}\right)$ volumes (ignoring the reduction in gasphase volume due to presence of the adsorbed phase.) Expressing Gibbs adsorption in terms of vapor volume $\left(\mathrm{V}_{\mathrm{gas}}\right)$ and adsorbed-phase volume $\left(\mathrm{V}_{\mathrm{ads}}\right)$, and using the specific molar volume ( $v_{\text {gas }}$ and $v_{\text {ads }}$ ), we obtain:

$$
\mathrm{n}_{\mathrm{ads}}^{\text {Gibbs }}=\mathrm{n}_{\mathrm{inj}}-\left[\frac{\mathrm{V}_{\text {gas }}+\mathrm{V}_{\mathrm{ads}}}{\mathrm{v}_{\text {gas }}}\right]
$$


For absolute adsorption, the amount adsorbed within the equilibrium cell is given as:

$$
\mathrm{n}_{\text {ads }}^{\text {Abs }}=\mathrm{n}_{\text {inj }}-\left[\frac{\mathrm{V}_{\text {gas }}}{\mathrm{V}_{\text {gas }}}\right]
$$

By combining Equations 5 and 6, the Gibbs adsorption expression can be rewritten as:

$$
\mathrm{n}_{\mathrm{ads}}^{\text {Abs }}=\mathrm{n}_{\text {ads }}^{\text {Gibbs }}+\left[\frac{\mathrm{V}_{\text {ads }}}{\mathrm{V}_{\text {gas }}}\right](7)
$$

Since

$$
\mathrm{V}_{\mathrm{ads}}=\mathrm{n}_{\mathrm{ads}}^{\mathrm{Abs}} \mathrm{v}_{\mathrm{ads}} \quad \text { and } \quad \mathrm{v}_{\mathrm{ads}}=\frac{1}{\rho_{\mathrm{ads}}}
$$

Then

$$
\mathrm{n}_{\mathrm{ads}}^{\text {Abs }}=\frac{\mathrm{n}_{\mathrm{ads}}^{\text {Gibbs }}}{\left[1-\left(\frac{\rho_{\text {gas }}}{\rho_{\text {ads }}}\right)\right]} \text {.(8) }
$$

where $\rho$ is density. At low pressures, the density-ratio correction is negligible, but at higher pressures it becomes significant.

A common approximation for the density of an adsorbed phase is to use the liquid density at the atmospheric pressure boiling point, as done by Yee [6]. However, more accurate estimates for the adsorbed-phase density are required when the adsorbed-phase density approaches the bulk gas density.

For multicomponent systems, the adsorbed-phase density, $\rho_{\text {ads }}$, in Equation 8 is replaced with the mixture adsorbed-phase density, which is assumed to be the adsorbed mole fraction weighted average of the pure-component phase volumes $\left(1 / \rho_{\text {ads, }}\right)$, i.e.:

$$
\rho_{\mathrm{ads}}=\frac{1}{\sum \frac{\mathrm{x}_{\mathrm{i}}^{\mathrm{Abs}}}{\rho_{\mathrm{ads}, \mathrm{i}}}}
$$

\section{Component Absolute Adsorption}

The component mole fraction in the adsorbed phase, $x_{i}^{A b s}$, is calculated based on the following derivation. Note that abbreviated subscripts are used for volumes to simplify documentation ( $g=$ gas, $a=a d s$, and $c=$ void). 


$$
n_{\text {inj }}(i)=\frac{V_{g}}{v_{g}} y_{i}+\frac{V_{a}}{v_{a}} x_{i}^{A b s}
$$

Since

$$
\mathrm{V}_{\mathrm{c}}=\mathrm{V}_{\mathrm{g}}+\mathrm{V}_{\mathrm{a}}=\mathrm{V}_{\text {void }}
$$

and substituting for $\mathrm{n}_{\mathrm{ads}}^{\text {Abs }}$ then

$$
n_{\text {inj }}(i)=\left[\frac{\left(V_{c}-v_{a}\right)}{v_{g}}\right] y_{i}+\left[\frac{n_{a d s}^{\text {Gibbs }}}{1-\frac{v_{a}}{v_{g}}}\right] x_{i}^{\text {Abs }}
$$

or

$$
n_{\text {inj }}(i)=\frac{V_{c}}{v_{g}} y_{i}-\frac{V_{a}}{v_{g}} y_{i}+\left[\frac{n_{a d s}^{G i b b s}}{1-\frac{v_{a}}{v_{g}}}\right] x_{i}^{A b s}
$$

Noting that

$$
\mathrm{n}_{\mathrm{ads}}^{\text {Gibs }}=\frac{\mathrm{V}_{\mathrm{a}}}{\mathrm{v}_{\mathrm{a}}}\left[1-\frac{\mathrm{v}_{\mathrm{a}}}{\mathrm{v}_{\mathrm{g}}}\right]=\left(\frac{\mathrm{V}_{\mathrm{a}}}{\mathrm{v}_{\mathrm{a}}}-\frac{\mathrm{V}_{\mathrm{a}}}{\mathrm{v}_{\mathrm{g}}}\right),
$$

which upon rearrangement leads to

$$
\frac{v_{a}}{v_{g}}=\frac{n_{a d s}^{G i b b s}}{\left(1-\frac{v_{a}}{v_{g}}\right)}-n_{a d s}^{\text {Gibbs }}=\left[\frac{1}{\left(1-\frac{v_{a}}{v_{g}}\right)}-1\right] n_{\text {ads }}^{\text {Gibbs }}=\left[\frac{\frac{v_{a}}{v_{g}}}{\left(1-\frac{v_{a}}{v_{g}}\right)}\right] n_{\text {ads }}^{\text {Gibbs }}
$$

Therefore, Equation 12 becomes

$$
n_{\text {inj }}(i)-\frac{v_{c}}{v_{g}} y_{i}=-\left[\frac{\frac{v_{a}}{v_{g}}}{\left(1-\frac{v_{a}}{v_{g}}\right)}\right] n_{\text {ads }}^{\text {Gibbs }} y_{i}+\left[\frac{n_{a d s}^{\text {Gibbs }}}{1-\frac{v_{a}}{v_{g}}}\right] x_{i}^{\text {Abs }}
$$


or

$$
\left(n_{\text {inj }}(i)-\frac{v_{c}}{v_{g}} y_{i}\right)\left(1-\frac{v_{a}}{v_{g}}\right)=\left[x_{i}^{A b s}-y_{i}\left(\frac{v_{a}}{v_{g}}\right)\right] n_{\text {ads }}^{\text {Gibbs }}(14)
$$

By definition

$$
\mathbf{X}_{\mathrm{i}}^{\text {Gibbs }}=\frac{\mathrm{n}_{\mathrm{ads}}^{\text {Gibbs }}(\mathrm{i})}{\mathrm{n}_{\mathrm{ads}}^{\text {Gibbs }}}
$$

Then

$$
x_{i}^{\text {Gibbs }}=\frac{\left(n_{\text {inj }}(i)-\frac{v_{c}}{v_{g}} y_{i}\right)}{n_{\text {ads }}^{\text {Gibbs }}}
$$

Then Equation 14 can be written as

$$
x_{i}^{\text {Gibbs }}\left(1-\frac{v_{a}}{v_{g}}\right)=x_{i}^{A b s}-y_{i}\left(\frac{v_{a}}{v_{g}}\right)
$$

For a binary system, Equation 15 becomes two equations:

$$
x_{1}^{G i b b s}=x_{1}^{A b s}+\left(x_{1}^{G i b b s}-y_{1}\right)\left[\frac{v_{a 1}}{v_{g}} x_{1}^{A b s}+\frac{v_{a 2}}{v_{g}} x_{2}^{A b s}\right]
$$

and

$$
x_{2}^{\text {Gibbs }}=x_{2}^{A b s}+\left(x_{2}^{\text {Gibbs }}-y_{2}\right)\left[\frac{v_{a 1}}{v_{g}} x_{1}^{A b s}+\frac{v_{a 2}}{v_{g}} x_{2}^{A b s}\right]
$$

Given the Gibbs adsorbed-phase compositions $\left(x_{1}^{\text {Gibbs }}, x_{2}^{\text {Gibbs }}\right)$ and the experimental gas-phase compositions $\left(\mathrm{y}_{1}, \mathrm{y}_{2}\right)$, absolute adsorbed-phase compositions are obtained by solving Equations 16 and 17 simultaneously. Once these compositions are obtained, the absolute adsorption of each individual component is calculated as follows:

$$
\mathrm{n}_{\mathrm{ads}}^{\text {Abs }}(\mathrm{i})=\mathrm{x}_{\mathrm{i}}^{\mathrm{Abs}} \mathrm{n}_{\mathrm{ads}}^{\text {Abs }}(18)
$$

\section{(b) Determination of Coal Particle Size Distribution}

A sieve analysis was use to determine the macro-particle size distribution. A series of meshes was selected: They were No. 3.5, 8, 10, 12, 20, 30, 40, 50 and 
60 with respective openings of $5.66,2.38,2.00,1.70,0.85,0.60,0.425,0.300$, $0.250 \mathrm{~mm}$. The analysis was performed on a pre-weighed in-situ coal sample. The sieves were stacked in order of mesh size. After sufficiently shaking the sample, we measured the weight of the contents remaining in each sieve to determine the respective proportion of the coal particle size distribution.

\section{(c) Determination of Coal Moisture Content}

A pre-weighed, as-received wet coal sample was placed into a pre-weighed container. The container was subjected to a continuous vacuum in a $215-220^{\circ} \mathrm{F}$ oven. Vacuum was applied overnight to remove moisture. After the moisture was removed, the container was re-weighed, and the difference was assumed to be from the moisture loss.

Another wet sample was placed on a flat pan in a $35.0^{\circ} \mathrm{C}$ air atmosphere at 97 $99 \%$ relative humidity. The sample weight was determined periodically to gauge the constancy of weight, which indicates the approach of the sample to equilibrium moisture content. Once a constant sample weight was achieved, the sample was assumed to be at its "equilibrium moisture content" or EMC.

The equilibrium sample was then placed in a continuous vacuum at $215-220^{\circ} \mathrm{F}$. The moisture loss determined by weight difference was used to calculate the EMC. For the Tiffany samples considered in this study, the moisture content of the as-received samples was found to be higher than the EMC.

\section{(d) Sorption-Time Measurements for Pure Gases}

To facilitate sorption-time measurements, an analog acquisition card was installed in our pressure console. Thus, a graphic representation of how pressure varies with time can be displayed in real time using conventional Excel tools. Temperature was also measured by a thermocouple and sent to an analog converter and then to the analog computer acquisition board.

A desorption step is initiated by reducing the equilibrium pressure of the adsorbed gas. This adsorption pressure reduction is accomplished by opening a valve connecting the equilibrium cell (where the coal sample is in contact with the adsorbate) to the injection pump, which is set at lower pressure. The valve between the cell and injection pump is opened as quickly as possible to simulate a step change in pressure. The coal sample then desorbs its gas, and the pressure rises from the initial desorption pressure $\left(P_{0}\right)$ to a new equilibrium pressure $\left(P_{f}\right)$. The pressure at any given time $\left(P_{t}\right)$ is monitored and recorded along with time $(\mathrm{t})$ by the data acquisition module. Thus, the sorption-time estimates are generated from the desorption-time increment involving $P_{0}$ and $P_{f}$, as depicted by the illustration below.

The pressure fractional uptake, $\Lambda$, is defined as: 


$$
\Lambda=\left(\mathrm{P}_{\mathrm{t}}-\mathrm{P}_{0}\right) /\left(\mathrm{P}_{\mathrm{f}}-\mathrm{P}_{0}\right)
$$

Here $P_{0}$ is the initial desorption pressure, $P_{f}$ is the final desorption pressure, and $P_{t}$ is the pressure at time t. Typically, a scaled-time plot produces a generalizeable desorption profile for different equilibrium pressures.

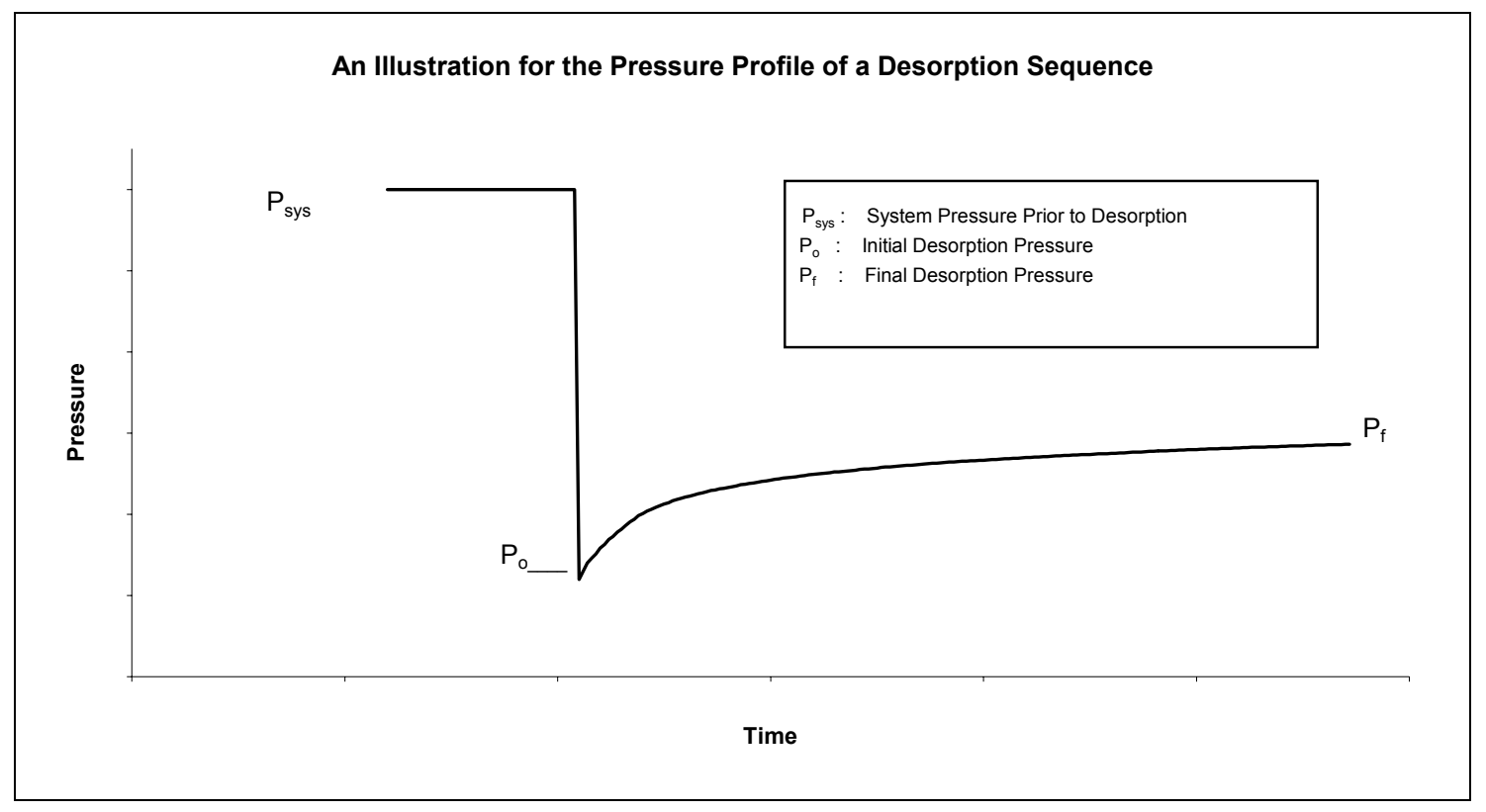

An alternative representation for the adsorption kinetics may be expressed in terms of sorption fractional uptake, defined as:

$$
\Theta=\left(\omega_{\mathrm{t}}-\omega_{0}\right) /\left(\omega_{\mathrm{f}}-\omega_{0}\right)=\left(\mathrm{V}_{\mathrm{SCF}_{\mathrm{t}}}-\mathrm{V}_{\mathrm{SCF}_{0}}\right) /\left(\mathrm{V}_{\mathrm{SCF}_{\mathrm{f}}}-\mathrm{V}_{\mathrm{SCF}_{0}}\right)
$$

where $\omega$ is the amount of gas adsorbed, and $\mathrm{V}_{\mathrm{SCF}}$ is the corresponding volume at the standard conditions. If a Langmuir-type model is used to correlate the equilibrium sorption data, then Equation 20 can be rewritten as:

$$
\Theta=\Lambda\left(\frac{1+B P_{f}}{1+B P_{t}}\right)
$$

where $\mathrm{B}$ is the Langmuir constant regressed from sorption experimental data.

\section{Data Correlation}

The newly acquired adsorption data on the Tiffany coal samples were correlated using (a) the extended Langmuir model, (b) the loading ratio correlation, and (c) 
the Zhou-Gasem-Robinson (ZGR) two-dimensional equation of state. Following is a brief description of the models used. An assessment for the quality of their representation and prediction of the present pure and mixture Tiffany coal data is presented in Section E.

\section{(a) Langmuir/Loading Ratio Correlation}

Historically, simple models have been used to represent the behavior of pure and mixed gas adsorption on coal. The extended Langmuir model is used almost exclusively in literature studies [e.g., 6], although the Ideal Adsorbed Solution (IAS) model has also been employed [7, 8]. Both of these models work well for essentially ideal adsorbed solutions, but neither is capable of handling nonidealities in the adsorbed phase with any accuracy. The extended Langmuir model is shown below as an illustration of the simple modeling approach used in most previous studies. For mixtures, it takes the form

$$
\theta_{i}=\frac{\omega_{i}}{L_{i}}=\frac{B_{i} P_{i}}{1+\sum_{j} B_{j} P_{j}}
$$

where $\omega_{\mathrm{i}}$ is the amount of component " $\mathrm{i}$ " adsorbed (SCF of "i" adsorbed per ton of coal), $L_{i}$ and $B_{i}$ are Langmuir constants for "i", $P$ is pressure, and $y_{i}$ is the mole fraction of " $\mathrm{i}$ " in the gas phase. This relation allows mixture adsorption to be predicted from pure-component data, since values of $L_{i}$ and $B_{i}$ may be determined from the pure-component form of Equation 22. For pure-fluid adsorption, Equation 22 reduces to the Langmuir model:

$$
\theta=\frac{\omega}{\mathrm{L}}=\frac{\mathrm{BP}}{1+\mathrm{BP}}
$$

The combined Langmuir-Freundlick adsorption isotherm, expressed in terms of $\omega$ $\mathrm{i}$, yields the loading ratio correlation (LRC) for mixtures:

$$
\theta_{i}=\frac{\omega_{i}}{L_{i}}=\frac{\left(B_{i} P y_{i}\right)^{\eta_{i}}}{1+\sum_{j}\left(B_{j} P_{j}\right)^{\eta_{j}}}
$$

The additional parameter $\left(\eta_{i}\right)$ in the LRC lends the Langmuir model more flexibility. Although the simplicity of Langmuir models is attractive, our data show that they are inadequate to represent the behavior of mixtures of the gases $\mathrm{CO}_{2}$, methane, and nitrogen. In fact, previously we found errors greater than $100 \%$ when the extended Langmuir model was applied to our data on the adsorption of nitrogen from nitrogen $+\mathrm{CO}_{2}$ mixtures [2] . 


\section{(b) ZGR Equation of State}

Simulations of coalbed gas recovery and $\mathrm{CO}_{2}$ sequestering require reliable, yet simple, analytic models beyond Langmuir-type correlations. Equation-of-state (EOS) frameworks offer an attractive potential for such requirements. A general two-dimensional EOS can be written as follows [9]:

$$
\left[\mathrm{A} \pi+\frac{\alpha \omega^{2}}{1+\mathrm{U} \beta \omega+\mathrm{W}(\beta \omega)^{2}}\right]\left[1-(\beta \omega)^{\mathrm{m}}\right]=\omega \mathrm{RT}
$$

where $A$ is the specific surface area, $\pi$ is the spreading pressure, $\omega$ is the specific amount adsorbed, and $\alpha, \beta$ and $\mathrm{m}$ are model parameters. The model coefficients, $\mathrm{U}, \mathrm{W}$, and $\mathrm{m}$ must be specified to obtain a specific form of the 2-D EOS for application. For example, an analog of the van der Waals (VDW) EOS is obtained by setting $m=1$ and $U=W=0$; similarly for the Soave-RedlichKwong (SRK) $(m=U=1$ and $W=0)$; the Peng-Robinson (PR) $(m=1, U=2$, and $W=-1)$; and the Eyring $(m=1 / 2$ and $U=W=0)$ EOS.

This general 2-D EOS can be used to investigate EOS behaviors by specifying various combinations of model coefficients. Selection of the model coefficient $\mathrm{m}$ is the most important among the EOS model coefficients, because it has a significant effect on the shape of the pure adsorption isotherm. If $U$ and $W$ are equal to zero, then by setting $m$ to values of $\infty, 1$, and 1/2, we obtain the 2-D ideal gas law, the VDW EOS, and the Eyring EOS, respectively. Actually, the pure gas isotherms vary considerably in shape and we have found that it is sometimes desirable to select an $m$ value even smaller than $1 / 2$ to describe pure isotherms. We have determined that an equation with $m=1 / 3$ and $U=W=0$ (the ZGR EOS) is promising [9]. The 2-D EOS can be applied to adsorbed phases containing mixtures by utilizing the traditional mixing rules (where $\mathrm{x}$ is the mole fraction in the adsorbed phase):

$$
\begin{aligned}
& \alpha=\sum_{i} \sum_{j} x_{i} x_{j} \alpha_{i j} \\
& \beta=\sum_{i} \sum_{j} x_{i} x_{j} \beta_{i j}
\end{aligned}
$$

along with the non-traditional combination rules [9],

$$
\begin{aligned}
& \alpha_{i j}=\left(1-C_{i j}\right)\left(\alpha_{i}+\alpha_{j}\right) / 2 \\
& \beta_{i j}=\left(1+D_{i j}\right) \sqrt{\beta_{i} \beta_{j}}
\end{aligned}
$$

where $C_{i j}$ and $D_{i j}$ are the EOS binary interaction parameters. 


\section{E. Results and Discussion}

\section{Experimental Data}

\section{(a) Comparison of Tiffany Coal Samples}

Coal characterization measurements are presented in Tables 1-3 and Figures 24. Table 1 presents the compositional analyses for coal samples from Wells \#1 and \#10. Table 2 and Figures 2-4 present the coal particle size distribution for the two samples. The analyses indicate that the two coal samples are similar in composition and particle size distribution.

The density of the compact solid coal is called the coal helium density, in reference to the helium displacement measurements used to determine the adsorbent density [10]. We have measured the coal helium densities for Well \#1, Well \#10, and the mixed sample. They are $1.73,1.57$, and $1.67 \pm 0.07 \mathrm{~g} / \mathrm{cc}$, respectively. The equilibrium moisture content of Well \#1 coal sample is $3.8 \pm 0.2 \%$ and the equilibrium moisture content of Well \#10 coal sample is $3.7 \pm 0.2 \%$.

Vitrinite reflectance analyses conducted by National Petrographic Services indicate that the present Tiffany coal samples are medium volatility bituminous coal. As summarized in Table 3, Wells \#1 and 10 have average oil-based vitrinite reflectance values of 1.31 and 1.35 , respectively.

Initial methane adsorption isotherms were measured separately for Wells \#1 and \#10. Results are presented in Tables 4 and 5 (on moisture-free and ash-free bases) and Figure 5. They indicate that the adsorption capacities of samples from the two wells are comparable with a maximum variation of $5 \%$ in the amount adsorbed at 2000 psia.

Because of the similarity in the methane adsorption behavior for Tiffany Well \#1 and Well \#10 coal samples, and upon agreement with BP Amoco personnel, coal samples from the two wells were mixed on an equal-mass basis. Large chunks of coal (dime-size) were broken up and the coal mixture was gently shaken to ensure a final homogenous mixture. The coal samples were placed into a tightlycapped jar. Helium was injected into the jar to prevent oxidation of the coal.

\section{(b) Adsorption Isotherms}

\section{Pure Gas Adsorption}

Gas adsorption measurements for pure methane, nitrogen and $\mathrm{CO}_{2}$ were conducted on wet Tiffany coal samples at $130^{\circ} \mathrm{F}$ and pressures to 2000 psia. Our error analysis indicates that the average uncertainties for the methane, nitrogen, and $\mathrm{CO}_{2}$ adsorption measurements are approximately $3 \%$ (9 SCF/ton), $6 \%$ (8 SCF/ton) and 7\% (62 SCF/ton), respectively. These estimates, which are 
depicted as error bars in some of the figures, were generated by error propagation of uncertainties in all measured quantities. The repeated isotherms confirm the estimated precision of the measurements.

The adsorption data are presented in Tables 4-8 and Figures 5-10. Figure 6 presents the Gibbs adsorption isotherms for methane, nitrogen, and $\mathrm{CO}_{2}$, respectively. The absolute adsorption data for these gases are presented in Figures 7-10. In this study, unless otherwise noted, we use the adsorbed-phase density approximation suggested by Yee [6]. For nitrogen, methane, and $\mathrm{CO}_{2}$, densities of $0.808,0.421$, and $1.18 \mathrm{~g} / \mathrm{cm}^{3}$, respectively, were used to convert the Gibbs to absolute adsorption.

Tables 4 and 5 present isotherms for methane on Well \#1 and Well \#10 coal samples, respectively. Replicate runs were conducted to confirm our measurements. These measurements show good agreement between the replicate runs, which yield an expected uncertainty of about $5 \%$. A four-point adsorption isotherm was measured on the Tiffany mixed coal sample, as presented in Table 6. As expected, the mixed coal sample produced an intermediate adsorption capacity; i.e., it shows less adsorption than the Well \#1 coal sample and more than the Well \#10 sample.

The replicate runs for methane (Figure 5 and Tables 4-6) show good agreement. The average expected uncertainty for these measurements is approximately $3 \%$ ( $9 \mathrm{SCF} /$ ton), as depicted by the error bars in Figure 5. (Notice that error bars are included only for one run).

The adsorption isotherm for pure nitrogen on the mixed Tiffany coal sample is presented in Table 7 and Figure 8 . As indicated by Figure 8, no significant differences exist between the replicate runs. The average expected uncertainty for these measurements is approximately $6 \%$ (8 SCF/ton). Similarly, adsorption isotherm measurements for pure $\mathrm{CO}_{2}$ on wet Tiffany mixed coal sample are given in Table 8 and Figure 9. The replicate runs show reasonable agreement with an average expected uncertainty of about $7 \%$ (62 SCF/ton).

Both methane and nitrogen adsorption measurements on Tiffany coal indicate lower adsorption capacity than the adsorption on the Fruitland coal reported previously [1]. The measurements on Tiffany coal are about one half that on Fruitland coal at the same conditions. This difference might be due to variations in coal composition. Ash content in Tiffany coal is about twice that of the Fruitland coal. In contrast, the carbon content in Tiffany coal is about two thirds that in Fruitland coal. Nevertheless, the new measurements agree with the previous ones in the relative amounts of nitrogen, methane and $\mathrm{CO}_{2}$ adsorbed, which are in the approximate ratio of $1: 2.7: 5$ at 1000 psia.

As previously reported [1], a slightly different moisture content in each measurement set indicates that water content values beyond the equilibrium water content have no significant effect the adsorption behavior. In contrast, the 
adsorbed-phase density estimates may affect the calculated absolute adsorption isotherm. Figure 10 illustrates the effect of variation in the adsorbed-phase density on the $\mathrm{CO}_{2}$ absolute adsorption. Here, three estimates are used: (1) the triple point liquid density $\left(1.18 \mathrm{~g} / \mathrm{cm}^{3}\right),(2)$ the ZGR model estimate $\left(1.25 \mathrm{~g} / \mathrm{cm}^{3}\right)$, and (3) a graphical estimate based on the Gibbs adsorption isotherm (1.40 $\mathrm{g} / \mathrm{cm}^{3}$ ). Differences in the calculated adsorption increase with pressure, rising to as much as $15 \%$ at 2000 psia.

\section{Binary Mixture Adsorption}

Adsorptions isotherms were measured for methane/nitrogen, methane $/ \mathrm{CO}_{2}$ and nitrogen $/ \mathrm{CO}_{2}$ on wet, mixed Tiffany coal at $130{ }^{\circ} \mathrm{F}$ and pressures to 2000 psia. The measurements were conducted at one feed composition for each mixture. The expected uncertainties in the amount adsorbed for these binary mixtures vary with pressure and composition. In general, percent average uncertainties are below 5\% (19 SCF/ton) for total adsorption; however, the expected uncertainties in the amount of individual-component adsorption are significantly higher for the less-adsorbed gas at lower molar feed concentrations (e.g., nitrogen in the $20 / 80$ nitrogen $/ \mathrm{CO}_{2}$ system).

Mixture absolute adsorption estimates were calculated assuming ideal-solution additive volumes in the condensed phase (i.e., the mixture volume is the molefraction-weighted average of the pure component volumes). The traditional values of $0.808 \mathrm{~g} / \mathrm{cm}^{3}, 0.421 \mathrm{~g} / \mathrm{cm}^{3}$, and $1.18 \mathrm{~g} / \mathrm{cm}^{3}$, were used to estimate the adsorbed-phase density of methane, nitrogen, and $\mathrm{CO}_{2}$, respectively.

Table 9 and Figure 11 present the experimental data for methane/nitrogen adsorption at the nominal molar feed composition of $50 \%$ methane. In general, the average expected uncertainties in the amount of individual-component adsorption are $7 \%$ (13 SCF/ton) for methane, and 17\% (8 SCF/ton) for nitrogen. The total adsorption has estimated uncertainties of 7\% (15 SCF/ton). Figure 12 presents the absolute adsorption for this binary system, including predictions from the LRC and ZGR models. As shown in Figures 11 and 12, methane is more strongly adsorbed than nitrogen.

Table 10 and Figure 13 present the experimental data of methane/ $\mathrm{CO}_{2}$ adsorption at a nominal molar feed composition of $40 \%$ methane. The average expected uncertainties in the amount of individual-component adsorption are $7 \%$ (10 SCF/ton) for methane, and 6\% (17 SCF/ton) for $\mathrm{CO}_{2}$. The total adsorption has estimated uncertainties of $4 \%$ ( $20 \mathrm{SCF} /$ ton). Figure 14 presents the absolute adsorption of this system, which indicates that the amount of $\mathrm{CO}_{2}$ adsorbed is almost three times that observed for methane.

Table 11 and Figure 15 present the experimental data of nitrogen/ $\mathrm{CO}_{2}$ adsorption at the nominal molar feed composition of $20 \%$ nitrogen. A small amount of nitrogen is adsorbed at this feed composition. This results in higher uncertainties for the nitrogen component adsorption, which could be around 29\% (8 SCF/ton). 
In comparison, the $\mathrm{CO}_{2}$ component adsorption has estimated uncertainties $6 \%$ (23 SCF/ton), and the total adsorption has estimated uncertainties of 5\% (22 SCF/ton). Figure 16 presents the absolute adsorption of this binary system, which indicates that the amount of $\mathrm{CO}_{2}$ adsorbed is almost 20 times that observed for nitrogen.

\section{Ternary Mixture Adsorption}

The ternary adsorption of methane/nitrogen/ $/ \mathrm{CO}_{2}$ on wet, mixed Tiffany coal at $130{ }^{\circ} \mathrm{F}$ and pressures to 2000 psia was conducted at 10/40/50 mole $\%$ feed composition. Table 12 and Figure 17 present the excess Gibbs adsorption data for this mixture, and Figure 18 depicts the absolute adsorption isotherms. The average expected uncertainty for the total adsorption and $\mathrm{CO}_{2}$ adsorption is about $5 \%$ (17 SCF/ton). However, the low adsorption of nitrogen and methane in this ternary yielded experimental uncertainties of 14\% (9 SCF/ton) and $27 \%$ (9 SCF/ton), respectively. The absolute adsorption data for this ternary were generated using the same procedure used for the binary mixtures.

\section{(c) Sorption-Time Estimates for Pure Gases}

Tables 13-16 present the desorption data for pure methane, nitrogen and $\mathrm{CO}_{2}$, respectively. The tables provide a record for a number of desorption runs for each gas off the Tiffany coal samples, where values for the initial desorption pressure, final desorption pressure and the time of desorption are given. In addition, information is shown for the $90 \%$ pressure fractional uptake, $\Lambda$; and the $63 \%$ sorption fractional uptake, $\Theta$.

Figure 19 presents three methane desorption runs for the Well \#1 coal sample. Similarly, Figure 20 presents two methane desorption runs for Well \#10 coal sample. The results for three nitrogen runs and six $\mathrm{CO}_{2}$ desorption runs off the Tiffany mixed coal sample are given in Figures 21 and 22, respectively. Other runs for the various gases, which are not included, show the same trend.

For the Well \#1 coal sample, the sorption time at $90 \%$ pressure uptake for methane varies from 8 minutes to 140 minutes depending on the pressure. For the Well \#10 coal sample, the $90 \%$ sorption time for methane varies from 4 minutes to 50 minutes depending on the pressure. Accordingly, methane desorption on Well \#10 coal is faster than on Well \#1 coal. Moreover, desorption at higher pressures is faster than desorption at lower pressures. Similar trends for the effect of pressure on sorption time are observed for nitrogen and $\mathrm{CO}_{2}$ on the Tiffany mixed coal sample. 


\section{Data Correlation and Model Evaluation}

\section{(a) Adsorption Isotherms}

The data correlation and model evaluation effort undertaken here addresses two important issues: (a) the ability of the LRC and ZGR EOS to correlate or represent the acquired adsorption data, and (b) the ability of the two models to predict the binary and ternary mixture adsorptions. Thus, beyond establishing the model precision in summarizing existing data, we are also interested in evaluating the efficacy of such models in using pure and/or binary measurements to provide accurate predictions for ternary and other multicomponent mixtures.

Accordingly, in the following discussion two case studies are considered. First, we evaluate model representations of the Tiffany adsorption data, where the model parameters (L, B, and $\eta$ for the LRC; $\alpha, \beta, C_{i j}, D_{i j}$ for ZGR EOS) are regressed to correlate the data considered and to establish the quality of precision attainable for the present models. Next, we examine binary model predictions based on pure-fluid parameters, and ternary predictions based on pure or a combination of pure and binary parameters.

The following weighted-error objective function was used to regress model parameters:

$$
\mathrm{SS}=\sum_{\mathrm{i}} \sum_{\mathrm{j}}\left(\frac{\omega_{\mathrm{ij}}^{\text {calc }}-\omega_{\mathrm{ij}}^{\text {exp } t}}{\sigma_{\mathrm{ij}}^{\text {exp } t}}\right)^{2} \quad \mathrm{i}=1, \mathrm{NPTS} ; \mathrm{j}=1, \mathrm{NC}(29)
$$

Here, $\mathrm{j}$ and $\mathrm{i}$ are component and data point indices, respectively, NC the total number of components in the mixture, NPTS the total number of data points, and $\sigma_{i j}^{\text {exp }}$ is the expected experimental uncertainty for the individual data point. The root-mean-square error (RMSE) and the \%AAD for the individual isotherms, calculated as

$$
\begin{aligned}
& \text { RMSE }=\sqrt{\frac{\sum_{i}^{\text {NPTS }}\left(\omega_{i}^{\text {calc }}-\omega_{i}^{\text {expt }}\right)^{2}}{\text { NPTS }}} \\
& \% A A D=100 \sum_{i}^{\text {NPSS }}\left|\frac{\omega_{i}^{\text {calc }}-\omega_{i}^{\text {exp } t}}{\omega_{i}^{\text {expt }}}\right|
\end{aligned}
$$

were used to express the quality of fit in our model evaluations. Similar expressions were used for the overall fit. 


\section{Pure Adsorption}

Tables 17-20 present a summary of our model evaluation results for the three models used to correlate the present adsorption data for methane, nitrogen, and $\mathrm{CO}_{2}$. The model parameters, shown in Tables 17-20, were determined by minimizing the sum of squares of weighted errors in the calculated adsorption, $\omega$, for the pure gas of interest (Equation 29).

Table 17 presents the results for the Langmuir model. AADs of 2 to $4 \%$ (4-17 SCF/ton) were obtained for the systems considered. Table 18 presents the results for the LRC using system-specific pressure exponents $\left(\eta_{i}\right)$. The results indicate that the LRC produces better quality fit than the Langmuir correlation for the three gases studied. This in part reflects the added flexibility gained by the additional parameter $\eta_{i}$ in the regressions. AADs of 1 to $2 \%$ (2-12 SCF/ton) were observed for the systems considered. When a common pressure exponent $\left(\eta_{i}\right)$ was forced on the model, a value of 0.90 was obtained. Table 19 presents the results of this LRC using the common exponent, which yielded an AAD of $1-2 \%$ (2-12 SCF/ton).

Table 20 presents a summary of our model evaluation results for ZGR EOS. These results reveal the ability of the ZGR EOS to represent the adsorption of $\mathrm{CO}_{2}$, methane and nitrogen on Tiffany coals within their expected experimental uncertainties. Similar to the LRC results, fits with 2 to $3 \%$ AAD (3-15 SCF/ton) were obtained.

Figures 7-10 illustrate the abilities of the LRC and ZGR models to describe the present pure-fluid adsorption data.

\section{Binary Mixture Adsorptions}

Figures 12, 14, and 16 present the LRC representations of the binary absolute adsorption data. The LRC parameters generated for these mixtures and the model statistics are given in Table 21. In general, AADs of $1-10 \%$ (1-19 SCF/ton) are observed for the individual-component adsorption. However, an AAD of $32 \%$ (11 SCF/ton) was obtained for the nitrogen adsorption in the nitrogen $/ \mathrm{CO}_{2}$ mixture adsorption.

Table 22 summarizes the results for the LRC predictions based on pure-gas adsorption data. As shown in this table, the LRC model predicts the methane/nitrogen and methane/ $\mathrm{CO}_{2}$ binary adsorptions within the experimental uncertainties (2-21\%, 5-42 SCF/ton) using pure-fluid adsorption parameters; however, the model predictions for the nitrogen $/ \mathrm{CO}_{2}$ binary are less accurate (AAD of $39 \%$ or $14 \mathrm{SCF} /$ ton for the nitrogen adsorption). Moreover, variation of the pressure exponent $\eta$ does not significantly change the results. Figures 23-25 illustrate the quality of the LRC predictions for the binary mixtures. 
Table 25 presents a summary of the evaluation results for ZGR EOS, where various binary parameter regressions have been considered. The results indicate that using two interaction parameters $\left(C_{i j}\right.$ and $\left.D_{i j}\right)$ leads to the best overall fit for the Tiffany coal adsorption data. Representations within the expected experimental uncertainty (AAD of 3-15\%, 3-33 SCF/ton) are obtained for the three binaries. Figures 12, 14, and 16 illustrate the abilities of the ZGR EOS to describe the present binary mixture adsorption data. In most cases, the ZGR and LRC give comparable results, with slightly better statistics for the LRC.

In addition, Table 25 summarizes the results for the ZGR predictions based on pure-gas adsorption data. As shown in this table and Figures 23-25, the ZGR EOS predicts the binary adsorption isotherms of methane/nitrogen and methane $/ \mathrm{CO}_{2}$ within twice the experimental uncertainty (about 1-27\%, 5-35 SCF/ton). Significantly higher deviations, however, are observed for the lessadsorbed nitrogen (up to $49 \% \mathrm{AAD}, 13 \mathrm{SCF} /$ ton) in the nitrogen/ $\mathrm{CO}_{2}$ binary.

\section{Ternary Mixture Adsorption}

Figure 18 presents the LRC representations of the ternary adsorption data. The LRC parameters generated for this mixture and the model statistics are given in Table 23. AAD of $3-12 \%$ (4-17 SCF/ton) are observed for the individual adsorption, and $3 \%$ (16 SCF/ton) for the total adsorption. The results suggest that the quality of fit is directly related to the amount adsorbed.

The predictive capability of the LRC is examined in Figure 26 and Table 24 . In this case, the LRC model parameters obtained from the pure adsorption were used to predict the ternary mixture adsorption on wet Tiffany coal. Poor model predictions were obtained for this ternary when only pure-adsorption data are utilized in model optimization. AAD of 5-45\% (2-55 SCF/ton) were observed for the individual-component isotherms. This translates roughly to prediction errors within one to four times the expected experimental uncertainty. Variation in the pressure exponent did not alter the results significantly.

Table 25 presents a summary the evaluation results for ZGR EOS, which indicate the ability of the ZGR EOS to predict the methane/nitrogen $/ \mathrm{CO}_{2}$ ternary adsorption isotherms within three times their expected experimental uncertainties (4-56\% AAD, 5-52 SCF/ton). The ZGR representations using binary interaction parameters $\left(C_{i j}, D_{i j}\right)$ are comparable to those obtained by the LRC using the same amount of input data. The ZGR binary interaction parameters generated for this mixture are also given in Table 25.

The predictive capability of the ZGR EOS is examined in Figure 26 and Table 25. The ZGR predictions based on pure $\left(\alpha_{i}, \beta_{i}\right.$, In $\left.k_{i}\right)$ and binary $\left(C_{i j}, D_{i j}\right)$ parameters are within three times the experimental uncertainty (10-32\% AAD, 5$49 \mathrm{SCF} / \mathrm{ton})$. However, the results indicate that for the present mixtures little improvement is realized by predicting the individual-component ternary isotherms 
based on parameters generated from both pure and binary adsorption data. Further, the quality of the model predictions indicate that although the LRC and ZGR EOS are capable of predicting total adsorption isotherms adequately, they predict the individual-component isotherms poorly, especially when dealing with the less-adsorbed component of the mixture. In fact, diminishing the influence of the less-adsorbed components on the parameter regressions, by using a leastsquares (un-weighted) objective function, improves the ternary model predictions based on pure and binary data.

These results suggest significant model improvements are required to realize the expected benefit of improving multicomponent predictions using binary adsorption measurements.

\section{(b) Sorption-Time Estimates for Pure Gases}

An empirical correlation was used to represent the sorption fractional uptake, $\Theta$ :

$$
\Theta=\frac{\beta t^{\alpha}}{1+\beta t^{\alpha}}
$$

where

$$
\alpha=\left(\mathrm{aP}^{2}+\mathrm{bP}+0.5\right) \mathrm{c}
$$

The coefficients $\beta, a, b$ and $c$ are regressed from sorption time data [8]. For the systems considered in this study, Equation 30 represents the sorption-time estimates on average within $8 \%$. Table 26 lists the regressed parameters for the gases considered, and Figures 27-30 present the correlated sorption curves for methane, nitrogen and $\mathrm{CO}_{2}$, respectively.

Table 27 and Figure 31 present time estimates for liberated gas off the Tiffany coal samples. The plot indicates that $\mathrm{CO}_{2}$ has the fastest sorption time followed by nitrogen and methane. Moreover, the sorption time for the three gases is within 12 minutes for $63 \%$ adsorbed-gas liberation. 


\section{F. Conclusions}

- Characterizations of BP Amoco Tiffany coal samples from Injection Wells \#1 and \#10 were done. Results for (a) particle size distribution, (b) composition, (c) equilibrium moisture content, and (d) vitrinite reflectance indicate similarity of the two samples.

- The vitrinite reflectance analysis indicates that the samples represent medium volatility bituminous coals.

- Adsorption isotherms for pure methane on the two wet Tiffany coal samples (Wells $\# 1$ and $\# 10$ ) at $130^{\circ} \mathrm{F}$ and pressures to 2000 psia confirmed the similarity of the two samples.

- Adsorption isotherms were then measured for pure methane, nitrogen and $\mathrm{CO}_{2}$ on a mixed Tiffany coal sample. The coal sample was an equal-mass mixture of coals from Well \#1 and Well \#10. The adsorption measurements were conducted at $130^{\circ} \mathrm{F}$ and pressures to 2000 psia. The adsorption capacity of the mixed sample is intermediate to that observed for Well \#1 and Well \#10 samples. The pure adsorption data have average expected experimental uncertainties of $3 \%$ (9 SCF/ton), $6 \%$ (8 SCF/ton) and $7 \%(62$ $\mathrm{SCF} /$ ton) for methane, nitrogen, and $\mathrm{CO}_{2}$, respectively.

- Sorption times were measured for pure methane, nitrogen and $\mathrm{CO}_{2}$. The measurements were correlated using a Langmuir-type equation, which yielded average errors within $8 \%$.

- Binary adsorption of methane/nitrogen, methane/ $/ \mathrm{CO}_{2}$ and nitrogen $/ \mathrm{CO}_{2}$ on a wet Tiffany mixed coal at $130{ }^{\circ} \mathrm{F}$ and pressures to 2000 psia were measured at one feed composition for each mixture. The expected uncertainties in the amount adsorbed for these binary mixtures vary with pressure and composition. In general, percent average uncertainties are about 7\% (19 SCF/ton) for total adsorption; however, the expected uncertainties in the amount of individual-component adsorption are significantly higher, especially at lower feed gas mole fractions (i.e., nitrogen in the nitrogen/ $\mathrm{CO}_{2}$ system at $20 / 80$ mole $\%$ feed composition).

- Ternary adsorption was measured for methane/nitrogen/ $/ \mathrm{CO}_{2}$ on a wet Tiffany mixed coal at $130^{\circ} \mathrm{F}$ and pressures to 2000 psia for a $10 / 40 / 50$ mole $\%$ feed composition. The average expected uncertainty for the total adsorption and $\mathrm{CO}_{2}$ adsorption is about $5 \%$ (17 SCF/ton). However, the low adsorption of nitrogen and methane in this ternary yielded experimental uncertainties of 14\% (9 SCF/ton) and 27\% (9 SCF/ton), respectively.

- Our newly acquired compressibility factor measurements for mixtures of methane/nitrogen/ $/ \mathrm{CO}_{2}$ allowed us to optimize the BWR EOS to predict accurately the $Z$ factors required for use in reduction of our mixture adsorption data. 
- The total adsorption data can be correlated within their experimental uncertainties by the loading ratio correlation (LRC) and the 2D Zhou-GasemRobinson (ZGR) equation of state (EOS).

- The present results suggest that both the LRC and ZGR EOS are capable of predicting binary adsorption isotherms based on pure-fluid adsorption parameters within twice their experimental uncertainties. In comparison, the ternary predictions based on pure-fluid parameters yield three times the experimental uncertainties. Further, for the present system, little improvement is realized by predicting the individual-component ternary isotherms based on parameters generated from both pure and binary adsorption data.

- The quality of the model predictions indicate that although the LRC and ZGR EOS are capable of predicting the total adsorption adequately, they predict the individual-component adsorption poorly, especially when dealing with the less-adsorbed component of the mixture. This suggests significant model improvements are required to realize the full benefit of improving multicomponent predictions using input from binary adsorption measurements. 


\section{G. References}

1. Hall, F. E., Zhou, Chunhe, Gasem, K. A. M., and Robinson, Jr., R. L., Adsorption of Pure Methane, Nitrogen, and Carbon Dioxide and their Binary Mixtures on Wet Fruitland Coal, SPE Paper 29194, presented at the 1994 Eastern Regional Conference \& Exhibition, Charleston, West Virginia, November 8-10, 1994.

2. Hall, F. E., Adsorption of Pure and Multicomponent Gases on Wet Fruitland Coal, M. S. Thesis, Oklahoma State University, December 1993.

3. Span, R. and Wagner, W., A New Equation of State for Carbon Dioxide Covering the Fluid Region from the Triple Point Temperature to $1100 \mathrm{~K}$ at Pressures up to $800 \mathrm{MPa}$, J. Phys. Chem. Ref. Data, $\underline{25}$, 1509-1590 (1996).

4. International Thermodynamic Tables of the Fluid State-5 Methane, Angus, S., Armstrong, B., de Reuck, K.M., IUPAC Chemical Data Series No.16, (1976).

5. International Thermodynamic Tables of the Fluid State-6 Nitrogen, Angus, S., Armstrong, B., de Reuck, K.M., IUPAC Chemical Data Series No.20, (1977).

6. Arri, L. E., and Yee, D., Modeling Coalbed Methane Production with Binary Gas Sorption, SPE Paper 24363, presented at the SPE Rocky Mountain Regional Meeting, Casper, Wyoming, May 18-21, 1992.

7. Myers, A. L., and Prausnitz, J. M., Thermodynamics of Mixed-Gas Adsorption, AIChE J. 11 121-129 (1965).

8. Stevenson, M. D., Pinczewski, W. V., Somers, M. L., and Bagio, S. E., Adsorption/Desorption of Multicomponent Gas Mixtures on Coal at In-Seam Conditions, SPE Paper 23026, presented at the SPE Asia-Pacific Conference, Perth, Western Australia, November 4-7, 1991.

9. Zhou, C., Gasem, K. A. M., and Robinson, Jr., R. L., Predicting Gas Adsorption Using Two-Dimensional Equations of State, I\&EC Research $\underline{33}$ 1280-1289 (1994).

10. Malbrunot, P., Vidal, D., and Vermesse, J., Storage of Gases at Room Temperature by Adsorption at High Pressure, Applied Thermal Engineering 16 375-382 (1996).

11.Pan, Z., Fitzgerald, J. E., Sudibandriyo, M., Gasem, K. A. M., and Robinson, Jr., R. L., Measurement and Correlation of Methane/Nitrogen/Carbon Dioxide Compressibility Factors, Journal of Thermodynamics, to be submitted, 2002. 


\section{H. Tables}

Table 1. Compositional Analyses of Tiffany Coal Samples*

\begin{tabular}{|l|r|r|r|r|}
\hline \multicolumn{1}{|c|}{ Analysis } & Well \#1 & Well \#10 & $\begin{array}{c}\text { Well \#1 } \\
\text { Dried Basis }\end{array}$ & $\begin{array}{c}\text { Well \#10 } \\
\text { Dried Basis }\end{array}$ \\
\hline Dry Loss \% & 6.85 & 18.33 & & \\
\hline Carbon \% & 44.51 & 46.35 & 47.78 & 56.75 \\
\hline Hydrogen \% & 3.20 & 4.30 & 2.62 & 2.77 \\
\hline Oxygen \% & 11.85 & 20.51 & 6.19 & 5.16 \\
\hline Nitrogen \% & 0.86 & 0.83 & 0.92 & 1.02 \\
\hline Sulfur \% & 0.53 & 0.42 & 0.57 & 0.52 \\
\hline Ash \% & 46.30 & 38.99 & 49.71 & 47.74 \\
\hline Proximate & & & & \\
\hline Volatile Matter \% & 14.41 & 12.54 & 15.48 & 15.35 \\
\hline Fixed Carbon \% & 32.43 & 30.14 & 34.82 & 36.91 \\
\hline
\end{tabular}

*Analysis was conducted on a mass basis by Huffman Laboratories, Inc., 4630 Indiana Street, Golden, CO 80405.

Table 2. Tiffany Coal Particle Size Distribution

\begin{tabular}{|c|c|c|c|}
\hline \multicolumn{2}{|c|}{ Size Range $\mathbf{( m m})$} & \multirow{2}{*}{ Well \#1 $\mathbf{*}$ W mass) } & \multirow{2}{*}{ Well $\mathbf{\text { (\% mass) }}$} \\
\cline { 1 - 2 } From & To & 4.0 & 5.0 \\
\hline 0.00 & 0.25 & 4.5 & 1.4 \\
\hline 0.25 & 0.30 & 7.5 & 3.3 \\
\hline 0.30 & 0.425 & 10.9 & 8.2 \\
\hline 0.425 & 0.60 & 13.9 & 15.0 \\
\hline 0.60 & 0.85 & 45.7 & 41.0 \\
\hline 0.85 & 1.70 & 2.5 & 5.6 \\
\hline 1.70 & 2.00 & 6.2 & 4.3 \\
\hline 2.00 & 2.38 & 4.7 & 15.6 \\
\hline 2.38 & 5.66 & 0.0 & 0.6 \\
\hline 5.66 & $\infty$ & & \\
\hline
\end{tabular}

Table 3. Vitrinite Reflectance Analysis*

\begin{tabular}{|l|c|c|}
\hline & Well \#1 & Well \#10 \\
\hline Average VRO & 1.31 & 1.35 \\
\hline Range & $1.19-1.43$ & $1.21-1.50$ \\
\hline Grain Count & 50 & 50 \\
\hline Rank & $\begin{array}{c}\text { Medium Volatility } \\
\text { Bituminous Coal }\end{array}$ & $\begin{array}{c}\text { Medium Volatility } \\
\text { Bituminous Coal }\end{array}$ \\
\hline
\end{tabular}

*Analysis was conducted by National Petrographic Service, Inc., 5933 Bellaire Blvd. Suite 108, Houston, TX 77081. 
Table 4. Pure Methane Adsorption on Wet Tiffany Well \#1 Coal at $130^{\circ} \mathrm{F}$ : $5.6 \%$ Moisture Content

\begin{tabular}{|c|c|c|c|c|c|}
\hline \multicolumn{3}{|c|}{ Run 1 (Moisture Free Basis) } & \multicolumn{3}{|c|}{ Run 2 (Moisture Free Basis) } \\
\hline $\begin{array}{c}\text { Pressure } \\
\text { (psia) }\end{array}$ & $\begin{array}{c}\text { Gibbs } \\
\text { Adsorption } \\
\text { (SCF/ton) }^{*}\end{array}$ & $\begin{array}{l}\text { Absolute } \\
\text { Adsorption } \\
\text { (SCF/ton) }\end{array}$ & $\begin{array}{c}\text { Pressure } \\
\text { (psia) }\end{array}$ & $\begin{array}{c}\text { Gibbs } \\
\text { Adsorption } \\
\text { (SCF/ton) }\end{array}$ & $\begin{array}{l}\text { Absolute } \\
\text { Adsorption } \\
\text { (SCF/ton) }\end{array}$ \\
\hline 62.0 & 43.2 & 43.5 & 322.5 & 141.7 & 146.4 \\
\hline 139.3 & 79.7 & 80.8 & 657.3 & 199.7 & 214.0 \\
\hline 298.3 & 138.6 & 142.8 & 1129.1 & 245.7 & 278.7 \\
\hline 485.0 & 176.9 & 186.0 & 1840.3 & 260.8 & 325.9 \\
\hline 655.5 & 205.9 & 220.6 & & & \\
\hline 898.3 & 234.1 & 258.0 & & & \\
\hline 1057.1 & 246.1 & 276.6 & & & \\
\hline 1235.1 & 254.7 & 292.9 & & & \\
\hline 1446.4 & 260.5 & 308.1 & & & \\
\hline 1728.1 & 264.2 & 324.9 & & & \\
\hline 1960.3 & 267.8 & 340.5 & & & \\
\hline
\end{tabular}

\begin{tabular}{|c|c|c|c|c|c|}
\hline \multicolumn{3}{|c|}{$\begin{array}{c}\text { Run } 1 \\
\text { (Moisture and Ash Free Basis) }\end{array}$} & \multicolumn{3}{|c|}{$\begin{array}{c}\text { Run } 2 \\
\text { (Moisture and Ash Free Basis) }\end{array}$} \\
\hline $\begin{array}{c}\text { Pressure } \\
\text { (psia) }\end{array}$ & $\begin{array}{c}\text { Gibbs } \\
\text { Adsorption } \\
\text { (SCF/ton) }\end{array}$ & $\begin{array}{l}\text { Absolute } \\
\text { Adsorption } \\
\text { (SCF/ton) }\end{array}$ & $\begin{array}{c}\text { Pressure } \\
\text { (psia) }\end{array}$ & $\begin{array}{c}\text { Gibbs } \\
\text { Adsorption } \\
\text { (SCF/ton) }\end{array}$ & $\begin{array}{l}\text { Absolute } \\
\text { Adsorption } \\
\text { (SCF/ton) }\end{array}$ \\
\hline 62.0 & 85.9 & 86.5 & 322.5 & 281.8 & 291.1 \\
\hline 139.3 & 158.4 & 160.7 & 657.3 & 397.1 & 425.5 \\
\hline 298.3 & 275.6 & 284.0 & 1129.1 & 488.5 & 554.2 \\
\hline 485.0 & 351.8 & 369.8 & 1840.3 & 518.6 & 648.1 \\
\hline 655.5 & 409.4 & 438.6 & & & \\
\hline 898.3 & 465.5 & 513.0 & & & \\
\hline 1057.1 & 489.3 & 550.1 & & & \\
\hline 1235.1 & 506.4 & 582.4 & & & \\
\hline 1446.4 & 518.0 & 612.7 & & & \\
\hline 1728.1 & 525.3 & 646.0 & & & \\
\hline 1960.3 & 532.5 & 677.0 & & & \\
\hline
\end{tabular}

${ }^{*} 1 \mathrm{mmol} / \mathrm{g}=758.98 \mathrm{SCF} / \mathrm{ton}$ 
Table 5. Pure Methane Adsorption on Wet Tiffany Well \#10 Coal at $130{ }^{\circ} \mathrm{F}$ : $16.5 \%$ Moisture Content

\begin{tabular}{|c|c|c|c|c|c|}
\hline \multicolumn{2}{|c|}{ Run 1 (Moisture Free Basis) } & \multicolumn{3}{c|}{ Run 2 (Moisture Free Basis) } \\
\hline Pressure & $\begin{array}{c}\text { Gibbs } \\
\text { Adsorption } \\
\text { (psia) }\end{array}$ & $\begin{array}{c}\text { Absolute } \\
\text { (SCF/ton) }\end{array}$ & $\begin{array}{c}\text { Pressure } \\
\text { (SCF/ton) }\end{array}$ & $\begin{array}{c}\text { Gibbs } \\
\text { Adsorption } \\
\text { (pCF/ton) }\end{array}$ & $\begin{array}{c}\text { Absolute } \\
\text { Adsorption } \\
\text { (SCF/ton) }\end{array}$ \\
\hline 81.2 & 48.8 & 49.1 & 251.1 & 108.3 & 111.0 \\
\hline 191.1 & 94.1 & 95.9 & 681.6 & 199.0 & 213.8 \\
\hline 375.5 & 145.5 & 151.1 & 1137.8 & 232.8 & 264.4 \\
\hline 591.6 & 189.8 & 201.9 & 1665.4 & 238.0 & 290.4 \\
\hline 809.1 & 219.3 & 239.2 & & & \\
\hline 1018.2 & 230.2 & 257.6 & & & \\
\hline 1194.5 & 238.6 & 273.0 & & & \\
\hline 1393.2 & 241.9 & 284.1 & & & \\
\hline 1599.8 & 243.5 & 294.1 & & & \\
\hline 1807.4 & 246.9 & 307.1 & & & \\
\hline 1975.9 & 250.6 & 319.4 & & & \\
\hline
\end{tabular}

\begin{tabular}{|c|c|c|c|c|c|}
\hline \multicolumn{3}{|c|}{$\begin{array}{c}\text { Run } 1 \\
\text { (Moisture and Ash Free Basis) } \\
\end{array}$} & \multicolumn{3}{|c|}{$\begin{array}{c}\text { Run } 2 \\
\text { (Moisture and Ash Free Basis) } \\
\end{array}$} \\
\hline $\begin{array}{l}\text { Pressure } \\
\text { (psia) }\end{array}$ & $\begin{array}{c}\text { Gibbs } \\
\text { Adsorption } \\
\text { (SCF/ton) }\end{array}$ & $\begin{array}{c}\text { Absolute } \\
\text { Adsorption } \\
\text { (SCF/ton) }\end{array}$ & $\begin{array}{c}\text { Pressure } \\
\text { (psia) }\end{array}$ & $\begin{array}{c}\text { Gibbs } \\
\text { Adsorption } \\
\text { (SCF/ton) }\end{array}$ & $\begin{array}{c}\text { Absolute } \\
\text { Adsorption } \\
\text { (SCF/ton) }\end{array}$ \\
\hline 81.2 & 93.4 & 94.1 & 251.1 & 207.2 & 212.6 \\
\hline 191.1 & 180.0 & 183.6 & 681.6 & 380.8 & 409.2 \\
\hline 375.5 & 278.4 & 289.2 & 1137.8 & 445.4 & 506.1 \\
\hline 591.6 & 363.2 & 386.3 & 1665.4 & 455.5 & 555.7 \\
\hline 809.1 & 419.6 & 457.6 & & & \\
\hline 1018.2 & 440.5 & 492.8 & & & \\
\hline 1194.5 & 456.6 & 522.3 & & & \\
\hline 1393.2 & 462.9 & 543.6 & & & \\
\hline 1599.8 & 465.9 & 562.8 & & & \\
\hline 1807.4 & 472.5 & 587.6 & & & \\
\hline 1975.9 & 479.5 & 611.1 & & & \\
\hline
\end{tabular}


Table 6. Pure Methane Adsorption on Wet Tiffany Mixed Coal Sample at $130{ }^{\circ} \mathrm{F}: 11.7 \%$ Moisture Content

\begin{tabular}{|c|c|c|}
\hline \multicolumn{3}{|c|}{ (Moisture Free Basis) } \\
\hline $\begin{array}{c}\text { Pressure } \\
\text { (psia) }\end{array}$ & $\begin{array}{c}\text { Gibbs Adsorption } \\
\text { (SCF/ton) }\end{array}$ & $\begin{array}{c}\text { Absolute Adsorption } \\
\text { (SCF/ton) }\end{array}$ \\
\hline 255.9 & 114.0 & 117.0 \\
\hline 824.9 & 223.1 & 243.9 \\
\hline 1210.2 & 247.4 & 283.6 \\
\hline 1796.9 & 254.8 & 316.6 \\
\hline
\end{tabular}

Table 7. Pure Nitrogen Adsorption on Wet Tiffany Mixed Coal Sample at $130{ }^{\circ} \mathrm{F}: 11.7 \%$ Moisture Content

\begin{tabular}{|c|c|c|c|c|c|}
\hline \multicolumn{3}{|c|}{ Run 1 (Moisture Free Basis) } & \multicolumn{3}{|c|}{ Run 2 (Moisture Free Basis) } \\
\hline $\begin{array}{c}\text { Pressure } \\
\text { (psia) }\end{array}$ & $\begin{array}{c}\text { Gibbs } \\
\text { Adsorption } \\
\text { (SCF/ton) }\end{array}$ & $\begin{array}{l}\text { Absolute } \\
\text { Adsorption } \\
\text { (SCF/ton) }\end{array}$ & $\begin{array}{c}\text { Pressure } \\
\text { (psia) }\end{array}$ & $\begin{array}{c}\text { Gibbs } \\
\text { Adsorption } \\
\text { (SCF/ton) }\end{array}$ & $\begin{array}{l}\text { Absolute } \\
\text { Adsorption } \\
\text { (SCF/ton) }\end{array}$ \\
\hline 126.8 & 23.5 & 23.7 & 106.6 & 18.0 & 18.1 \\
\hline 222.7 & 35.2 & 35.9 & 202.9 & 29.4 & 29.9 \\
\hline 418.3 & 54.3 & 56.4 & 406.0 & 51.0 & 52.9 \\
\hline 615.7 & 67.8 & 71.7 & 602.7 & 66.0 & 69.7 \\
\hline 808.7 & 81.7 & 88.0 & 795.6 & 82.0 & 88.1 \\
\hline 1008.9 & 91.9 & 100.8 & 1000.2 & 93.4 & 102.3 \\
\hline 1211.4 & 99.8 & 111.6 & 1202.5 & 102.1 & 113.9 \\
\hline 1404.6 & 108.4 & 123.4 & 1410.9 & 111.2 & 126.6 \\
\hline 1615.8 & 118.9 & 138.1 & 1604.9 & 119.0 & 138.0 \\
\hline 1817.6 & 125.8 & 148.9 & 1806.2 & 124.5 & 147.2 \\
\hline 1994.8 & 132.5 & 159.5 & & & \\
\hline
\end{tabular}


Table 8. Pure $\mathrm{CO}_{2}$ Adsorption on Wet Tiffany Mixed Coal Sample at $130{ }^{\circ} \mathrm{F}$ : $11.7 \%$ Moisture Content

\begin{tabular}{|c|c|c|c|c|c|}
\hline \multicolumn{3}{|c|}{ Run 1 (Moisture Free Basis) } & \multicolumn{3}{|c|}{ Run 2 (Moisture Free Basis) } \\
\hline $\begin{array}{c}\text { Pressure } \\
\text { (psia) }\end{array}$ & $\begin{array}{c}\text { Gibbs } \\
\text { Adsorption } \\
\text { (SCF/ton) }\end{array}$ & $\begin{array}{l}\text { Absolute } \\
\text { Adsorption } \\
\text { (SCF/ton) }\end{array}$ & $\begin{array}{c}\text { Pressure } \\
\text { (psia) }\end{array}$ & $\begin{array}{c}\text { Gibbs } \\
\text { Adsorption } \\
\text { (SCF/ton) }\end{array}$ & $\begin{array}{l}\text { Absolute } \\
\text { Adsorption } \\
\text { (SCF/ton) }\end{array}$ \\
\hline 69.5 & 149.6 & 150.6 & 97.3 & 175.1 & 176.7 \\
\hline 204.5 & 273.1 & 278.8 & 526.8 & 383.0 & 406.6 \\
\hline 400.7 & 362.8 & 378.8 & 1028.3 & 417.2 & 486.1 \\
\hline 624.3 & 408.0 & 439.4 & 1504.0 & 357.1 & 515.4 \\
\hline 813.3 & 422.3 & 469.5 & 1956.1 & 281.5 & 575.6 \\
\hline 1010.0 & 423.0 & 490.6 & & & \\
\hline 1209.1 & 403.6 & 496.8 & & & \\
\hline 1402.1 & 372.3 & 501.2 & & & \\
\hline 1590.5 & 335.2 & 520.2 & & & \\
\hline 1784.6 & 303.4 & 555.7 & & & \\
\hline 1976.5 & 271.0 & 560.1 & & & \\
\hline
\end{tabular}


Table 9. Methane/Nitrogen Adsorption on a Wet Tiffany Mixed Coal Sample at $130{ }^{\circ} \mathrm{F}: \mathbf{1 0 . 5} \%$ Moisture Content

\begin{tabular}{|c|c|c|c|c|c|c|c|c|}
\hline \multirow{4}{*}{$\begin{array}{l}\text { Pressure } \\
\text { (psia) }\end{array}$} & \multicolumn{6}{|c|}{ Adsorption (SCF/ton dry coal) } & \multirow{2}{*}{\multicolumn{2}{|c|}{$\begin{array}{l}\text { Phase Compositions } \\
\text { (Mole Fraction Methane) }\end{array}$}} \\
\hline & \multicolumn{2}{|c|}{ Total } & \multicolumn{2}{|c|}{ Methane } & \multicolumn{2}{|c|}{ Nitrogen } & & \\
\hline & Gibbs & Absolute & Gibbs & Absolute & Gibbs & Absolute & \multirow[t]{2}{*}{ Gas } & \multirow[t]{2}{*}{ Adsorbed } \\
\hline & \multicolumn{6}{|c|}{ Methane Feed Composition: $50.0 \%$} & & \\
\hline 118.5 & 45.9 & 46.4 & 36.9 & 37.1 & 9.0 & 9.3 & 0.432 & 0.799 \\
\hline 220.1 & 79.2 & 80.8 & 63.8 & 64.5 & 15.3 & 16.3 & 0.436 & 0.798 \\
\hline 400.0 & 120.0 & 124.7 & 98.4 & 100.6 & 21.6 & 24.1 & 0.444 & 0.806 \\
\hline 611.6 & 155.5 & 165.1 & 126.6 & 130.9 & 28.9 & 34.1 & 0.454 & 0.793 \\
\hline 813.8 & 180.4 & 195.7 & 152.1 & 159.1 & 28.3 & 36.6 & 0.456 & 0.813 \\
\hline 1005.9 & 199.1 & 220.4 & 167.3 & 177.1 & 31.8 & 43.3 & 0.461 & 0.804 \\
\hline 1208.5 & 212.7 & 240.7 & 183.2 & 196.2 & 29.4 & 44.5 & 0.464 & 0.815 \\
\hline 1409.7 & 223.8 & 258.7 & 193.4 & 209.5 & 30.4 & 49.3 & 0.467 & 0.810 \\
\hline 1609.6 & 233.7 & 276.6 & 203.6 & 223.8 & 30.1 & 52.8 & 0.469 & 0.809 \\
\hline 1812.8 & 241.5 & 292.5 & 207.8 & 231.9 & 33.7 & 60.6 & 0.473 & 0.793 \\
\hline 2010.8 & 251.5 & 311.6 & 216.4 & 244.9 & 35.1 & 66.7 & 0.474 & 0.786 \\
\hline
\end{tabular}

* - Based on absolute adsorption 
Table 10. Methane/ $/ \mathrm{CO}_{2}$ Adsorption on a Wet Tiffany Mixed Coal Sample at $130{ }^{\circ} \mathrm{F}: 11.4 \%$ Moisture Content

\begin{tabular}{|c|c|c|c|c|c|c|c|c|}
\hline \multirow{4}{*}{$\begin{array}{l}\text { Pressure } \\
\text { (psia) }\end{array}$} & \multicolumn{6}{|c|}{ Adsorption (SCF/ton dry coal) } & \multirow{2}{*}{\multicolumn{2}{|c|}{$\begin{array}{l}\text { Phase Compositions } \\
\text { (Mole Fraction Methane) }\end{array}$}} \\
\hline & \multicolumn{2}{|c|}{ Total } & \multicolumn{2}{|c|}{ Methane } & \multicolumn{2}{|c|}{ Carbon Dioxide } & & \\
\hline & Gibbs & Absolute & Gibbs & Absolute & Gibbs & Absolute & \multirow[t]{2}{*}{ Gas } & \multirow[t]{2}{*}{ Adsorbed } \\
\hline & \multicolumn{6}{|c|}{ Methane Feed Composition: $41.4 \%$} & & \\
\hline 105.3 & 136.1 & 137.5 & 35.9 & 36.7 & 100.2 & 100.9 & 0.541 & 0.267 \\
\hline 210.0 & 209.7 & 214.1 & 49.6 & 52.0 & 160.1 & 162.1 & 0.530 & 0.243 \\
\hline 402.4 & 288.6 & 301.1 & 67.7 & 73.8 & 220.9 & 227.2 & 0.500 & 0.245 \\
\hline 601.4 & 334.6 & 357.0 & 70.7 & 81.7 & 263.9 & 275.4 & 0.488 & 0.229 \\
\hline 820.7 & 361.7 & 397.0 & 76.0 & 92.7 & 285.8 & 304.4 & 0.473 & 0.234 \\
\hline 1010.0 & 374.4 & 422.2 & 75.4 & 97.6 & 299.0 & 324.6 & 0.465 & 0.231 \\
\hline 1214.0 & 379.1 & 441.7 & 79.2 & 107.7 & 299.9 & 334.0 & 0.455 & 0.244 \\
\hline 1409.3 & 376.8 & 454.6 & 80.6 & 115.4 & 296.2 & 339.1 & 0.449 & 0.254 \\
\hline 1609.3 & 370.4 & 464.6 & 82.6 & 124.2 & 287.8 & 340.3 & 0.443 & 0.268 \\
\hline 1806.7 & 361.5 & 473.1 & 85.4 & 134.2 & 276.1 & 338.9 & 0.438 & 0.284 \\
\hline 2034.8 & 344.0 & 474.7 & 90.2 & 146.7 & 253.7 & 328.0 & 0.432 & 0.309 \\
\hline
\end{tabular}

* - Based on absolute adsorption 
Table 11. Nitrogen $/ \mathrm{CO}_{2}$ Adsorption on a Wet Tiffany Mixed Coal Sample at $130{ }^{\circ} \mathrm{F}: 10.4 \%$ Moisture Content

\begin{tabular}{|c|c|c|c|c|c|c|c|c|}
\hline \multirow{4}{*}{$\begin{array}{l}\text { Pressure } \\
\text { (psia) }\end{array}$} & \multicolumn{6}{|c|}{ Adsorption (SCF/ton dry coal) } & \multirow{2}{*}{\multicolumn{2}{|c|}{$\begin{array}{l}\text { Phase Compositions } \\
\text { (Mole Fraction Nitrogen) }\end{array}$}} \\
\hline & \multicolumn{2}{|c|}{ Total } & \multicolumn{2}{|c|}{ Nitrogen } & \multicolumn{2}{|c|}{ Carbon Dioxide } & & \\
\hline & Gibbs & Absolute & Gibbs & Absolute & Gibbs & Absolute & \multirow[t]{2}{*}{ Gas } & \multirow[t]{2}{*}{ Adsorbed* } \\
\hline & \multicolumn{6}{|c|}{ Nitrogen Feed Composition: $20.1 \%$} & & \\
\hline 91.8 & 143.1 & 144.4 & 4.3 & 4.8 & 138.7 & 139.6 & 0.363 & 0.033 \\
\hline 196.3 & 230.7 & 235.1 & 6.6 & 8.0 & 224.1 & 227.1 & 0.325 & 0.034 \\
\hline 402.7 & 324.7 & 338.4 & 6.5 & 10.5 & 318.2 & 327.9 & 0.289 & 0.031 \\
\hline 602.9 & 371.4 & 396.3 & 6.9 & 13.6 & 364.5 & 382.8 & 0.268 & 0.034 \\
\hline 824.4 & 398.4 & 438.1 & 5.5 & 15.5 & 392.9 & 422.6 & 0.253 & 0.035 \\
\hline 1011.5 & 405.4 & 458.7 & 9.9 & 22.7 & 395.5 & 436.0 & 0.241 & 0.050 \\
\hline 1213.7 & 403.4 & 472.8 & 8.5 & 24.7 & 394.9 & 448.2 & 0.233 & 0.052 \\
\hline 1407.7 & 395.2 & 481.5 & 8.7 & 28.3 & 386.5 & 453.2 & 0.227 & 0.059 \\
\hline 1604.3 & 376.1 & 479.3 & 6.5 & 29.5 & 369.5 & 449.8 & 0.223 & 0.062 \\
\hline 1805.2 & 352.6 & 473.7 & 5.4 & 31.9 & 347.2 & 441.8 & 0.219 & 0.067 \\
\hline 2004.2 & 336.8 & 478.6 & 4.2 & 34.9 & 332.6 & 443.7 & 0.216 & 0.073 \\
\hline
\end{tabular}

* - Based on absolute adsorption 
Table 12. Adsorption of a $10 / 40 / 50$ Mole $\%$ Methane/Nitrogen $/ \mathrm{CO}_{2}$ Feed Mixture on a Wet Tiffany Mixed Coal Sample at $130{ }^{\circ} \mathrm{F}: \mathbf{1 0 . 5 \%}$ Moisture Content

\begin{tabular}{|c|c|c|c|c|c|c|c|c|}
\hline \multirow{3}{*}{$\begin{array}{l}\text { Pressure } \\
\text { (psia) }\end{array}$} & \multicolumn{8}{|c|}{ Adsorption (SCF/ton dry coal) } \\
\hline & \multicolumn{2}{|c|}{ Total } & \multicolumn{2}{|c|}{ Methane } & \multicolumn{2}{|c|}{ Nitrogen } & \multicolumn{2}{|c|}{ Carbon Dioxide } \\
\hline & Gibbs & Absolute & Gibbs & Absolute & Gibbs & Absolute & Gibbs & Absolute \\
\hline 102.3 & 95.4 & 96.2 & 9.1 & 9.2 & 14.6 & 15.1 & 71.7 & 71.9 \\
\hline 199.3 & 158.9 & 161.7 & 13.3 & 13.6 & 19.4 & 21.0 & 126.2 & 127.0 \\
\hline 393.1 & 239.4 & 248.1 & 18.1 & 19.1 & 23.4 & 28.2 & 197.9 & 200.8 \\
\hline 612.6 & 291.6 & 308.8 & 20.8 & 22.7 & 26.9 & 36.0 & 243.8 & 250.1 \\
\hline 807.2 & 319.5 & 345.4 & 21.9 & 24.8 & 30.1 & 43.2 & 267.6 & 277.4 \\
\hline 1008.8 & 337.1 & 372.7 & 21.7 & 25.7 & 30.6 & 48.2 & 284.8 & 298.8 \\
\hline 1206.4 & 345.1 & 390.5 & 22.0 & 27.1 & 31.5 & 53.4 & 291.7 & 310.0 \\
\hline 1410.7 & 349.8 & 406.1 & 20.7 & 27.0 & 30.9 & 57.6 & 298.2 & 321.5 \\
\hline 1607.6 & 346.9 & 413.0 & 21.6 & 28.9 & 32.3 & 63.2 & 293.0 & 320.8 \\
\hline 1808.6 & 344.2 & 420.4 & 22.8 & 31.2 & 34.0 & 69.4 & 287.3 & 319.8 \\
\hline 2005.4 & 342.7 & 429.4 & 25.2 & 34.5 & 35.6 & 75.6 & 281.9 & 319.2 \\
\hline
\end{tabular}


Table 12. (Continued) Adsorption of a 10/40/50 Mole $\%$ Methane/Nitrogen/ $\mathrm{CO}_{2}$ Feed Mixture on a Wet Tiffany Mixed Coal Sample at $130{ }^{\circ} \mathrm{F}: \mathbf{1 0 . 5 \%}$ Moisture Content

\begin{tabular}{|c|c|c|c|c|c|c|}
\hline \multirow{3}{*}{$\begin{array}{l}\text { Pressure } \\
\text { (psia) }\end{array}$} & \multicolumn{6}{|c|}{ Phase Compositions (Mole \%) } \\
\hline & \multicolumn{2}{|c|}{ Methane } & \multicolumn{2}{|c|}{ Nitrogen } & \multicolumn{2}{|c|}{ Carbon Dioxide } \\
\hline & Gas & Adsorbed* & Gas & Adsorbed* & Gas & Adsorbed* \\
\hline 102.3 & 0.107 & 0.095 & 0.543 & 0.157 & 0.350 & 0.748 \\
\hline 199.3 & 0.112 & 0.084 & 0.537 & 0.130 & 0.352 & 0.786 \\
\hline 393.1 & 0.112 & 0.077 & 0.514 & 0.114 & 0.374 & 0.810 \\
\hline 612.6 & 0.111 & 0.074 & 0.491 & 0.116 & 0.398 & 0.810 \\
\hline 807.2 & 0.111 & 0.072 & 0.476 & 0.125 & 0.414 & 0.803 \\
\hline 1008.8 & 0.110 & 0.069 & 0.464 & 0.129 & 0.426 & 0.802 \\
\hline 1206.4 & 0.109 & 0.069 & 0.455 & 0.137 & 0.436 & 0.794 \\
\hline 1410.7 & 0.109 & 0.067 & 0.448 & 0.142 & 0.443 & 0.792 \\
\hline 1607.6 & 0.107 & 0.070 & 0.442 & 0.153 & 0.451 & 0.777 \\
\hline 1808.6 & 0.106 & 0.074 & 0.436 & 0.165 & 0.457 & 0.761 \\
\hline 2005.4 & 0.105 & 0.081 & 0.432 & 0.176 & 0.463 & 0.743 \\
\hline
\end{tabular}

* - Based on absolute adsorption 
Table 13. Desorption Time for Methane on Wet Tiffany Well \#1 Coal Sample at $130^{\circ} \mathrm{F}$

\begin{tabular}{|c|c|c|c|c|}
\hline \multicolumn{2}{|c|}{$\begin{array}{c}\text { Equilibrium Pressures (psia) } \\
\text { Initial } \\
\text { System }\end{array}$} & \multicolumn{2}{|c|}{$\begin{array}{c}\text { Time at } \Lambda=\mathbf{0 . 9} \\
\text { Desin) }\end{array}$} & $\begin{array}{c}\text { Time at } \Theta=\mathbf{0 . 6 3} \\
(\mathbf{m i n})\end{array}$ \\
\cline { 2 - 3 } & From & \multicolumn{1}{|c|}{ To } & & \\
\hline 1958.2 & 1697.1 & 1722.8 & 7.5 & 0.6 \\
\hline 1722.8 & 1496.9 & 1519.4 & 11.1 & 0.9 \\
\hline 1519.4 & 1288.7 & 1310.6 & 17.4 & 1.4 \\
\hline 1310.6 & 1098.4 & 1115.7 & 21.8 & 1.7 \\
\hline 1115.7 & 894.4 & 911.8 & 28.2 & 2.2 \\
\hline 911.8 & 682.3 & 704.6 & 44.0 & 3.5 \\
\hline 704.6 & 484.3 & 505.6 & 56.3 & 4.5 \\
\hline 283.9 & 43.1 & 87.1 & 169.0 & 14.6 \\
\hline
\end{tabular}

Table 14. Desorption Time for Methane on Wet Tiffany Well \#10 Coal Sample at $130^{\circ} \mathrm{F}$

\begin{tabular}{|c|c|c|c|c|}
\hline \multicolumn{2}{|c|}{ Equilibrium Pressures $(\mathbf{p s i a})$} & \multirow{2}{*}{$\begin{array}{c}\text { Time at } \Lambda=\mathbf{0 . 9} \\
\text { (min) }\end{array}$} & $\begin{array}{c}\text { Time at } \Theta=\mathbf{0 . 6 3} \\
(\mathbf{m i n})\end{array}$ \\
\cline { 1 - 3 } $\begin{array}{c}\text { Initial } \\
\text { System }\end{array}$ & \multicolumn{2}{|c|}{ Desorption } & & \\
\hline 1976.4 & 1650.0 & 1678.2 & 4.4 & 0.3 \\
\hline 1678.2 & 1351.0 & 1377.2 & 8.0 & 0.6 \\
\hline 1377.2 & 1071.5 & 1098.7 & 8.8 & 0.7 \\
\hline 649.1 & 430.4 & 460.1 & 8.4 & 0.7 \\
\hline 460.1 & 242.4 & 324.7 & 26.1 & 2.3 \\
\hline 324.7 & 142.4 & 238.1 & 40.3 & 3.7 \\
\hline
\end{tabular}

Table 15. Desorption Time for Nitrogen on Wet Tiffany Mixed Coal Sample at $130^{\circ} \mathrm{F}$

\begin{tabular}{|c|c|c|c|c|}
\hline \multicolumn{2}{|c|}{ Equilibrium Pressures (psia) } & \multirow{2}{*}{$\begin{array}{c}\text { Time at } \Lambda=0.9 \\
\text { (min) }\end{array}$} & $\begin{array}{c}\text { Time at } \Theta=\mathbf{0 . 6 3} \\
\text { (min) }\end{array}$ \\
\cline { 1 - 3 } $\begin{array}{c}\text { Initial } \\
\text { System }\end{array}$ & \multicolumn{2}{|c|}{ Desorption } & & \\
\hline 1954.4 & 1304.4 & 1310.1 & 22.0 & 4.0 \\
\hline 1310.1 & 716.0 & 728.7 & 30.0 & 5.6 \\
\hline 728.7 & 325.0 & 332.2 & 60.0 & 7.2 \\
\hline 332.2 & 40.7 & 42.3 & 60.0 & 12.0 \\
\hline
\end{tabular}


Table 16. Adsorption Time for $\mathrm{CO}_{2}$ on Wet Tiffany Mixed Coal Sample at $130^{\circ} \mathrm{F}$

\begin{tabular}{|c|c|c|c|c|}
\hline \multicolumn{2}{|c|}{ Equilibrium Pressures (psia) } & \multirow{2}{*}{$\begin{array}{c}\text { Time at } \Lambda=0.9 \\
\text { (min) }\end{array}$} & $\begin{array}{c}\text { Time at } \Theta=\mathbf{0 . 6 3} \\
(\mathbf{m i n})\end{array}$ \\
\cline { 2 - 3 } $\begin{array}{c}\text { Initial } \\
\text { System }\end{array}$ & \multicolumn{2}{|c|}{ Adsorption } & & \\
\hline 3.0 & 159.2 & 69.5 & 39.5 & 2.9 \\
\hline 69.5 & 462.0 & 400.7 & 27.6 & 2.5 \\
\hline 400.7 & 662.0 & 624.3 & 22.0 & 2.2 \\
\hline 624.3 & 834.0 & 813.3 & 15.6 & 2.0 \\
\hline 813.3 & 1031.0 & 1010.0 & 10.7 & 1.8 \\
\hline 1010.0 & 1233.0 & 1209.1 & 8.4 & 1.6 \\
\hline
\end{tabular}

Table 17. Langmuir Model Representation of Adsorption on Wet Tiffany Coals at $130{ }^{\circ} \mathrm{F}$

\begin{tabular}{|l|c|c|c|c|c|}
\hline \multicolumn{1}{|c|}{ Pure Gas } & $\begin{array}{c}\mathbf{L} \\
(\mathbf{S C F} / \text { ton })\end{array}$ & $\begin{array}{c}\mathbf{B} \times \mathbf{1 0 0 0} \\
\left(\mathbf{p s i a}^{-1}\right)\end{array}$ & $\eta$ & $\begin{array}{c}\text { RMSE } \\
(\mathbf{S C F} / \text { ton })\end{array}$ & \%AAD \\
\hline $\mathrm{CH}_{4}$ (Well \#1) & $\mathbf{4 3 2 . 0}$ & $\mathbf{1 . 6 1 0 7}$ & $\mathbf{1 . 0}$ & $\mathbf{4 . 2}$ & $\mathbf{1 . 9}$ \\
\hline $\mathrm{CH}_{4}$ (Well \#10) & $\mathbf{4 1 7 . 5}$ & $\mathbf{1 . 5 6 5 4}$ & $\mathbf{1 . 0}$ & $\mathbf{2 . 6}$ & $\mathbf{1 . 1}$ \\
\hline $\mathrm{CH}_{4}$ (Mixed Coal) & $\mathbf{4 3 4 . 9}$ & $\mathbf{1 . 5 0 7 4}$ & $\mathbf{1 . 0}$ & $\mathbf{7 . 2}$ & $\mathbf{2 . 6}$ \\
\hline $\mathrm{N}_{2}$ (Mixed Coal) & $\mathbf{2 6 6 . 9}$ & $\mathbf{0 . 6 3 0 3}$ & $\mathbf{1 . 0}$ & $\mathbf{3 . 9}$ & $\mathbf{3 . 5}$ \\
\hline $\mathrm{CO}_{2}$ (Mixed Coal) & $\mathbf{5 9 0 . 9}$ & $\mathbf{4 . 5 1 2 1}$ & $\mathbf{1 . 0}$ & $\mathbf{1 6 . 6}$ & $\mathbf{2 . 0}$ \\
\hline
\end{tabular}

Table 18. LRC Model Representation of Adsorption on Wet Tiffany Coals at $130^{\circ} \mathrm{F}$

\begin{tabular}{|l|c|c|c|c|c|}
\hline Pure Gas & $\begin{array}{c}\mathbf{L} \\
\text { (SCF/ton) }\end{array}$ & $\begin{array}{c}\mathbf{B \times 1 0 0 0} \\
\left(\mathbf{p s i a}^{-1} \text { ) }\right.\end{array}$ & $\eta$ & $\begin{array}{c}\text { RMSE } \\
\text { (SCF/ton) }\end{array}$ & \%AAD \\
\hline $\mathrm{CH}_{4}$ (Well \#1) & 509.0 & 1.1089 & 0.89 & 2.9 & 0.8 \\
\hline $\mathrm{CH}_{4}$ (Well \#10) & 440.7 & 1.3946 & 0.96 & 2.8 & 0.9 \\
\hline $\mathrm{CH}_{4}$ (Mixed Coal) & 491.8 & 1.1113 & 0.91 & 7.4 & 2.3 \\
\hline $\mathrm{N}_{2}$ (Mixed Coal) & 416.3 & 0.2708 & 0.87 & 2.2 & 2.1 \\
\hline $\mathrm{CO}_{2}$ (Mixed Coal) & 631.2 & 3.9299 & 0.91 & 12.4 & 1.8 \\
\hline
\end{tabular}


Table 19. LRC Model Representation of Adsorption on Wet, Mixed Tiffany Coals at $130^{\circ} \mathrm{F}$ (common $\left.\eta\right)$

\begin{tabular}{|l|c|c|c|c|c|}
\hline \multicolumn{1}{|c|}{ Pure Gas } & L (SCF/ton) & $\begin{array}{c}\text { Bx1000 } \\
\left(\text { psia }^{-1}\right)\end{array}$ & $\eta$ & $\begin{array}{c}\text { RMSE } \\
\text { (SCF/ton) }\end{array}$ & \%AAD \\
\hline $\mathbf{C H}_{\mathbf{4}}$ & 504.4 & 1.0854 & 0.90 & 7.6 & 2.3 \\
\hline $\mathbf{N}_{\mathbf{2}}$ & 364.6 & 0.3512 & 0.90 & 2.4 & 2.3 \\
\hline $\mathbf{C O}_{\mathbf{2}}$ & 634.8 & 3.8024 & 0.90 & 12.2 & 1.8 \\
\hline
\end{tabular}

Table 20. ZGR Equation-of-State Representation of Adsorption on Wet, Mixed Tiffany Coals at $130^{\circ} \mathrm{F}$

\begin{tabular}{|l|c|c|c|c|c|}
\hline Pure Gas & $\alpha$ & $\beta$ & - Ink & $\begin{array}{c}\text { RMSE } \\
\text { (SCF/ton) }\end{array}$ & \%AAD \\
\hline $\mathrm{CH}_{4}$ & 144770 & 1.0140 & 2.84 & 8.1 & 3.0 \\
\hline $\mathrm{N}_{2}$ & 193160 & 1.3926 & 4.29 & 1.7 & 2.3 \\
\hline $\mathrm{CO}_{2}$ & 74425 & 0.6069 & 1.26 & 15.4 & 2.1 \\
\hline
\end{tabular}

Table 21. LRC Model Representation of Binary Adsorption on Wet Tiffany Coals at $130^{\circ} \mathrm{F}$

\begin{tabular}{|l|c|c|c|c|c|}
\hline \multicolumn{1}{|c|}{ Mixture } & $\begin{array}{c}\mathbf{L} \\
\text { (SCF/ton) }\end{array}$ & $\begin{array}{c}\mathbf{B x 1 0 0 0} \\
\left(\mathbf{p s i a}^{-1}\right)\end{array}$ & $\eta$ & $\begin{array}{c}\text { RMSE } \\
\text { (SCF/ton) }\end{array}$ & \%AAD \\
\hline $\mathbf{C H}_{4}-\mathbf{N}_{2}:$ & 435.8 & 1.522 & 0.96 & 16.6 & 9.7 \\
$\mathrm{CH}_{4}$ & 366.6 & 0.337 & 0.89 & 5.8 & 9.0 \\
$\mathrm{~N}_{2}$ & & & & 20.9 & 8.2 \\
Total & & & & & \\
\hline $\mathbf{C H}_{4}-\mathbf{C O}_{2}:$ & 435.8 & 1.522 & 0.96 & 12.0 & 7.3 \\
$\mathrm{CH}_{4}$ & 702.6 & 2.868 & 0.80 & 17.0 & 4.2 \\
$\mathrm{CO}_{2}$ & & & & 5.5 & 1.2 \\
$\mathrm{Total}$ & & & & & \\
$\mathbf{N}_{2}-\mathrm{CO}_{2}:$ & 366.6 & 0.337 & 0.89 & 11.3 & 31.6 \\
$\mathrm{~N}_{2}$ & 702.6 & 2.868 & 0.80 & 36.2 & 6.7 \\
$\mathrm{CO}_{2}$ & & & & 26.2 & 4.7 \\
$\mathrm{Total}$ & & & & & \\
\hline Pure: $_{\mathrm{CH}_{4}}$ & 435.8 & 1.522 & 0.96 & 8.3 & 3.3 \\
$\mathrm{~N}_{2}$ & 366.6 & 0.337 & 0.89 & 2.9 & 2.7 \\
$\mathrm{CO}_{2}$ & 702.6 & 2.868 & 0.80 & 12.6 & 2.1 \\
\hline
\end{tabular}


Table 22. LRC Model Predictions of Binary Adsorption on Wet Tiffany Coals at $130^{\circ} \mathrm{F}$

\begin{tabular}{|c|c|c|c|c|c|c|}
\hline \multirow[t]{2}{*}{ Mixture } & \multicolumn{2}{|c|}{$\eta=1$ (Langmuir) } & \multicolumn{2}{|c|}{ Regressed $\eta$} & \multicolumn{2}{|c|}{$\eta=0.90$} \\
\hline & $\begin{array}{c}\text { RMSE } \\
\text { (SCF/ton) }\end{array}$ & \%AAD & $\begin{array}{c}\text { RMSE } \\
\text { (SCF/ton) }\end{array}$ & \%AAD & $\begin{array}{c}\text { RMSE } \\
\text { (SCF/ton) }\end{array}$ & $\% A A D$ \\
\hline $\begin{array}{l}\mathrm{CH}_{\mathbf{4}}-\mathbf{N}_{\mathbf{2}}: \\
\mathrm{CH}_{4} \\
\mathrm{~N}_{2} \\
\text { Total }\end{array}$ & $\begin{array}{c}29.5 \\
3.8 \\
30.2\end{array}$ & $\begin{array}{c}15.8 \\
6.2 \\
12.2\end{array}$ & $\begin{array}{c}15.5 \\
4.0 \\
16.2\end{array}$ & $\begin{array}{l}9.0 \\
8.3 \\
6.4\end{array}$ & $\begin{array}{c}23.2 \\
3.8 \\
21.7\end{array}$ & $\begin{array}{c}12.0 \\
9.3 \\
8.2\end{array}$ \\
\hline $\begin{array}{l}\mathrm{CH}_{4}-\mathrm{CO}_{2}: \\
\mathrm{CH}_{4} \\
\mathrm{CO}_{2} \\
\text { Total }\end{array}$ & $\begin{array}{c}36.5 \\
39.1 \\
4.9\end{array}$ & $\begin{array}{c}25.9 \\
9.0 \\
1.2\end{array}$ & $\begin{array}{l}31.3 \\
42.5 \\
11.2\end{array}$ & $\begin{array}{c}21.1 \\
10.1 \\
1.9\end{array}$ & $\begin{array}{l}31.4 \\
44.1 \\
12.8\end{array}$ & $\begin{array}{c}21.0 \\
10.5 \\
2.2\end{array}$ \\
\hline $\begin{array}{l}\mathrm{N}_{\mathbf{2}}-\mathbf{C O}_{\mathbf{2}}: \\
\mathrm{N}_{2} \\
\mathrm{CO}_{2} \\
\text { Total }\end{array}$ & $\begin{array}{l}15.2 \\
27.7 \\
15.9\end{array}$ & $\begin{array}{c}44.9 \\
5.2 \\
3.5\end{array}$ & $\begin{array}{l}14.1 \\
35.6 \\
22.7\end{array}$ & $\begin{array}{c}38.9 \\
5.9 \\
3.8\end{array}$ & $\begin{array}{l}13.7 \\
33.1 \\
21.1\end{array}$ & $\begin{array}{c}37.3 \\
5.7 \\
3.8\end{array}$ \\
\hline
\end{tabular}

Table 23. LRC Model Representation of Ternary Adsorption on Wet Tiffany Coals at $130^{\circ} \mathrm{F}$

\begin{tabular}{|l|c|c|c|c|c|}
\hline $\begin{array}{c}\text { Individual } \\
\text { Adsorption }\end{array}$ & $\begin{array}{c}\mathbf{L} \\
\text { (SCF/ton) }\end{array}$ & $\begin{array}{c}\text { Bx1000 } \\
\text { (psia }\end{array}$ & $\eta$ & $\begin{array}{c}\text { RMSE } \\
\text { (SCF/ton) }\end{array}$ & \%AAD \\
\hline $\mathrm{CH}_{4}$ & 478.2 & 1.8205 & 0.97 & 4.2 & 9.0 \\
\hline $\mathrm{N}_{2}$ & 212.8 & 2.0495 & 1.30 & 8.1 & 11.7 \\
\hline $\mathrm{CO}_{2}$ & 631.2 & 4.4225 & 1.05 & 12.8 & 3.3 \\
\hline Total & & & & 1.7 & 0.5 \\
\hline
\end{tabular}


Table 24. LRC Model Predictions of Ternary Adsorption on Wet Tiffany Coals at $130{ }^{\circ} \mathrm{F}$

\begin{tabular}{|c|c|c|c|c|c|}
\hline $\begin{array}{l}\text { Individual } \\
\text { Adsorption }\end{array}$ & $\begin{array}{c}\mathrm{L} \\
\text { (SCF/ton) }\end{array}$ & $\begin{array}{l}\text { BX1000 } \\
\left.\left(p^{2}\right)^{-1}\right)\end{array}$ & $\eta$ & $\begin{array}{c}\text { RMSE } \\
\text { (SCF/ton) }\end{array}$ & $\begin{array}{c}\% \\
\text { AAD }\end{array}$ \\
\hline \multicolumn{6}{|c|}{ Parameters based on pure data } \\
\hline \multicolumn{6}{|c|}{$\eta=1$ (Langmuir) } \\
\hline $\mathrm{CH}_{4}$ & 434.9 & 1.507 & 1.0 & 5.9 & 20.7 \\
\hline $\mathrm{N}_{2}$ & 266.9 & 0.630 & 1.0 & 29.8 & 47.8 \\
\hline $\mathrm{CO}_{2}$ & 590.9 & 4.512 & 1.0 & 49.6 & 13.2 \\
\hline Total & & & & 14.9 & 2.9 \\
\hline \multicolumn{6}{|c|}{$\eta$ Regressed } \\
\hline $\mathrm{CH}_{4}$ & 491.8 & 1.111 & 0.91 & 2.1 & 5.3 \\
\hline $\mathrm{N}_{2}$ & 416.3 & 0.271 & 0.87 & 29.6 & 46.1 \\
\hline $\mathrm{CO}_{2}$ & 631.2 & 3.930 & 0.91 & 61.4 & 17.7 \\
\hline Total & & & & 30.5 & 6.7 \\
\hline \multicolumn{6}{|c|}{$\eta=0.90$} \\
\hline $\mathrm{CH}_{4}$ & 504.4 & 1.085 & 0.90 & 2.2 & 5.2 \\
\hline $\mathrm{N}_{2}$ & 364.6 & 0.351 & 0.90 & 28.2 & 44.5 \\
\hline $\mathrm{CO}_{2}$ & 634.8 & 3.802 & 0.90 & 54.7 & 15.8 \\
\hline Total & & & & 24.9 & 5.4 \\
\hline \multicolumn{6}{|c|}{ Parameters based on pure and binary data } \\
\hline $\mathrm{CH}_{4}$ & 435.8 & 1.522 & 0.96 & 4.6 & 16.6 \\
\hline $\mathrm{N}_{2}$ & 366.6 & 0.337 & 0.89 & 25.1 & 45.8 \\
\hline $\mathrm{CO}_{2}$ & 702.6 & 2.868 & 0.80 & 43.9 & 12.0 \\
\hline Total & & & & 26.1 & 6.0 \\
\hline
\end{tabular}


Table 25. ZGR EOS Representation of Mixtures on Tiffany Mixed Coal at $130^{\circ} \mathrm{F}$

\begin{tabular}{|c|c|c|c|c|c|c|c|c|}
\hline \multicolumn{3}{|c|}{ Mixture } & \multicolumn{3}{|c|}{$\% A A D$} & \multicolumn{3}{|c|}{$\begin{array}{c}\text { RMSE } \\
\text { (SCF/ton coal) }\end{array}$} \\
\hline \multicolumn{9}{|c|}{$C_{i j}=D_{i j}=0$} \\
\hline & $\mathrm{C}_{\mathrm{ij}}$ & $D_{i j}$ & $\omega_{1}$ & $\omega_{2}$ & Total & $\omega_{1}$ & $\omega_{2}$ & Total \\
\hline $\mathrm{CH}_{4} / \mathrm{N}_{2}$ & 0.000 & 0.000 & 11.9 & 10.0 & 11.5 & 20.5 & 6.7 & 26.3 \\
\hline $\mathrm{CH}_{4} / \mathrm{CO}_{2}$ & 0.000 & 0.000 & 27.0 & 10.4 & 1.4 & 30.2 & 35.0 & 5.4 \\
\hline $\mathrm{N}_{2} / \mathrm{CO}_{2}$ & 0.000 & 0.000 & 48.7 & 4.9 & 3.5 & 13.1 & 25.4 & 15.6 \\
\hline \multicolumn{9}{|c|}{ Regressed $C_{i j}\left(D_{i j}=0\right)$} \\
\hline & $\mathrm{C}_{\mathrm{ij}}$ & $D_{i j}$ & $\omega_{1}$ & $\omega_{2}$ & Total & $\omega_{1}$ & $\omega_{2}$ & Total \\
\hline $\mathrm{CH}_{4} / \mathrm{N}_{2}$ & -0.090 & 0.000 & 10.6 & 7.3 & 7.6 & 18.8 & 3.9 & 17.5 \\
\hline $\mathrm{CH}_{4} / \mathrm{CO}_{2}$ & -0.125 & 0.000 & 8.4 & 10.6 & 6.1 & 11.2 & 32.9 & 25.4 \\
\hline $\mathrm{N}_{2} / \mathrm{CO}_{2}$ & -0.140 & 0.000 & 16.0 & 4.1 & 3.2 & 3.9 & 20.9 & 17.7 \\
\hline \multicolumn{9}{|c|}{ Regressed $D_{i j}\left(C_{i j}=0\right)$} \\
\hline & $\mathrm{C}_{\mathrm{ij}}$ & $D_{i j}$ & $\omega_{1}$ & $\omega_{2}$ & Total & $\omega_{1}$ & $\omega_{2}$ & Total \\
\hline $\mathrm{CH}_{4} / \mathrm{N}_{2}$ & 0.000 & -0.068 & 10.6 & 7.1 & 7.5 & 18.4 & 3.8 & 16.9 \\
\hline $\mathrm{CH}_{4} / \mathrm{CO}_{2}$ & 0.000 & -0.090 & 7.7 & 11.0 & 6.6 & 9.6 & 34.7 & 28.6 \\
\hline $\mathrm{N}_{2} / \mathrm{CO}_{2}$ & 0.000 & -0.108 & 14.5 & 4.3 & 3.5 & 3.3 & 21.8 & 19.0 \\
\hline \multicolumn{9}{|c|}{ Regressed $C_{i j}$ and $D_{i j}$} \\
\hline & $\mathrm{C}_{\mathrm{ij}}$ & $D_{i j}$ & $\omega_{1}$ & $\omega_{2}$ & Total & $\omega_{1}$ & $\omega_{2}$ & Total \\
\hline $\mathrm{CH}_{4} / \mathrm{N}_{2}$ & -0.060 & -0.023 & 10.6 & 7.2 & 7.5 & 18.7 & 3.8 & 17.3 \\
\hline $\mathrm{CH}_{4} / \mathrm{CO}_{2}$ & -0.098 & -0.019 & 8.2 & 10.7 & 6.2 & 10.9 & 33.2 & 26.1 \\
\hline $\mathrm{N}_{2} / \mathrm{CO}_{2}$ & -0.011 & -0.100 & 14.6 & 4.3 & 3.4 & 3.4 & 21.7 & 18.9 \\
\hline \multicolumn{9}{|c|}{ Predicted Ternary } \\
\hline Mixture & \multicolumn{4}{|c|}{$\% A A D$} & \multicolumn{4}{|c|}{$\begin{array}{c}\text { RMSE } \\
\text { (SCF/ton coal) }\end{array}$} \\
\hline \multicolumn{9}{|c|}{ From pure data $C_{i j}=D_{i j}=0$} \\
\hline & $\omega_{1}$ & $\omega_{2}$ & $\omega_{3}$ & Total & $\omega_{1}$ & $\omega_{2}$ & $\omega_{3}$ & Total \\
\hline $\mathrm{CH}_{4} / \mathrm{N}_{2} / \mathrm{CO}_{2}$ & 21.6 & 55.9 & 17.6 & 4.3 & 4.9 & 29.2 & 51.5 & 18.1 \\
\hline \multicolumn{9}{|c|}{$C_{i j}$ from Binary $\left(D_{i j}=0\right)$} \\
\hline & $\omega_{1}$ & $\omega_{2}$ & $\omega_{3}$ & Total & $\omega_{1}$ & $\omega_{2}$ & $\omega_{3}$ & Total \\
\hline $\mathrm{CH}_{4} / \mathrm{N}_{2} / \mathrm{CO}_{2}$ & 18.0 & 32.8 & 17.4 & 9.3 & 4.6 & 17.1 & 48.1 & 35.2 \\
\hline \multicolumn{9}{|c|}{$D_{i j}$ from Binary $\left(C_{i j}=0\right)$} \\
\hline & $\omega_{1}$ & $\omega_{2}$ & $\omega_{3}$ & Total & $\omega_{1}$ & $\omega_{2}$ & $\omega_{3}$ & Total \\
\hline $\mathrm{CH}_{4} / \mathrm{N}_{2} / \mathrm{CO}_{2}$ & 18.3 & 31.6 & 17.7 & 9.7 & 4.8 & 16.1 & 49.6 & 37.9 \\
\hline \multicolumn{9}{|c|}{$C_{i j}$ and $D_{i j}$ from Binary } \\
\hline & $\omega_{1}$ & $\omega_{2}$ & $\omega_{3}$ & Total & $\omega_{1}$ & $\omega_{2}$ & $\omega_{3}$ & Total \\
\hline $\mathrm{CH}_{4} / \mathrm{N}_{2} / \mathrm{CO}_{2}$ & 18.6 & 31.9 & 17.6 & 9.6 & 4.8 & 16.4 & 49.1 & 37.1 \\
\hline
\end{tabular}


Table 26. Sorption Fractional Uptake Correlation

\begin{tabular}{|l|l|c|c|}
\hline Pure Gas & \multicolumn{1}{|c|}{$\alpha=\left(\mathbf{a P} \mathbf{P}^{2}+\mathbf{b P + 0 . 5}\right) \mathbf{c}$} & $\beta$ & \%AAD \\
\hline $\mathrm{CH}_{4}($ Well \#1) & $\left(-5.530 \times 10^{-8} \times \mathrm{P}^{2}+2.960 \times 10^{-4} \times \mathrm{P}+0.5\right)(1.030)$ & 0.4570 & 4.1 \\
\hline $\mathrm{CH}_{4}$ (Well \#10) & $\left(1.251 \times 10^{-8} \times \mathrm{P}^{2}+7.397 \times 10^{-4} \times \mathrm{P}+0.5\right)(1.327)$ & 0.3912 & 6.4 \\
\hline $\mathrm{N}_{2}$ (Mixed Coal) & $(0.5) \times 1.700$ & 0.2833 & 7.2 \\
\hline $\mathrm{CO}_{2}$ (Mixed Coal) & $\left.1.264 \times 10^{-7} \times \mathrm{P}^{2}+9.497 \times 10^{-5} \times \mathrm{P}+0.5\right)(1.066)$ & 0.6404 & 2.2 \\
\hline
\end{tabular}

Table 27. Sorption-Time Estimates on Wet Tiffany Coal Samples at $130^{\circ} \mathrm{F}$ for 63\% Desorption

\begin{tabular}{|c|c|c|c|c|}
\hline $\begin{array}{c}\text { Starting } \\
\text { Desorption } \\
\text { Pressure } \\
\text { (psia) }\end{array}$ & $\begin{array}{c}\text { Methane on } \\
\text { Well \#1 } \\
\text { (min) }\end{array}$ & $\begin{array}{c}\text { Methane on } \\
\text { Well \#10 } \\
\text { (min) }\end{array}$ & $\begin{array}{c}\text { Nitrogen on } \\
\text { Mixed Coal } \\
\text { (min) }\end{array}$ & $\begin{array}{c}\mathbf{C O}_{2} \text { on Mixed } \\
\text { Coal } \\
(\mathbf{m i n})\end{array}$ \\
\hline 2000 & 9.3 & 8.4 & 8.2 & 4.7 \\
\hline 1800 & 9.4 & 8.4 & 8.2 & 4.7 \\
\hline 1600 & 9.5 & 8.5 & 8.2 & 4.7 \\
\hline 1400 & 9.6 & 8.5 & 8.2 & 4.7 \\
\hline 1200 & 9.8 & 8.5 & 8.2 & 4.7 \\
\hline 1000 & 9.9 & 8.6 & 8.2 & 4.7 \\
\hline 800 & 10.2 & 8.6 & 8.2 & 4.7 \\
\hline 600 & 10.5 & 8.7 & 8.2 & 4.7 \\
\hline 400 & 10.9 & 8.8 & 8.2 & 4.8 \\
\hline 200 & 11.6 & 9.0 & 8.2 & 4.8 \\
\hline
\end{tabular}


This page intentionally left blank. 
Figure 1. Schematic Diagram of Adsorption Apparatus

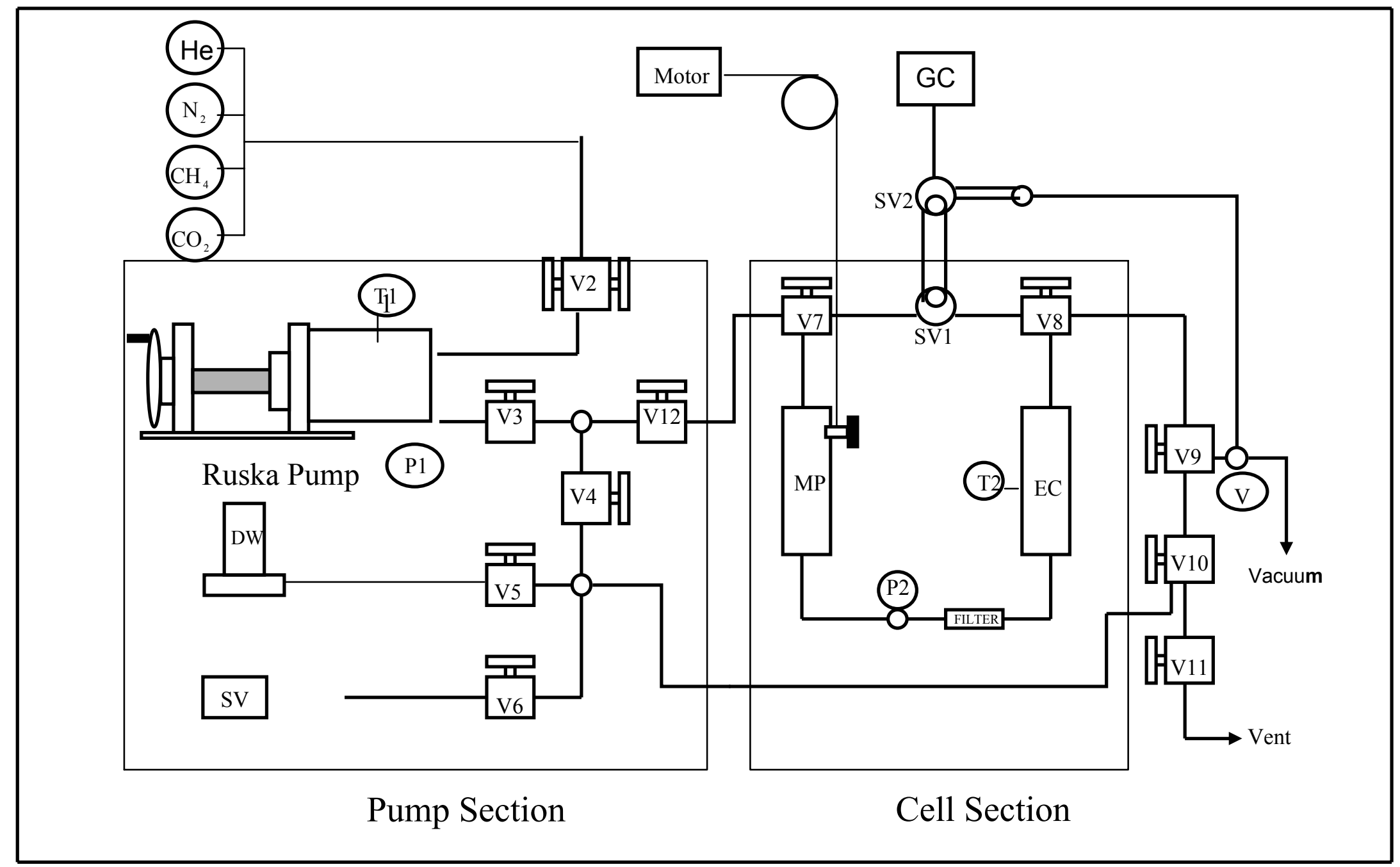


Figure 2. Tiffany Well \#1 Coal Particle Size Distribution

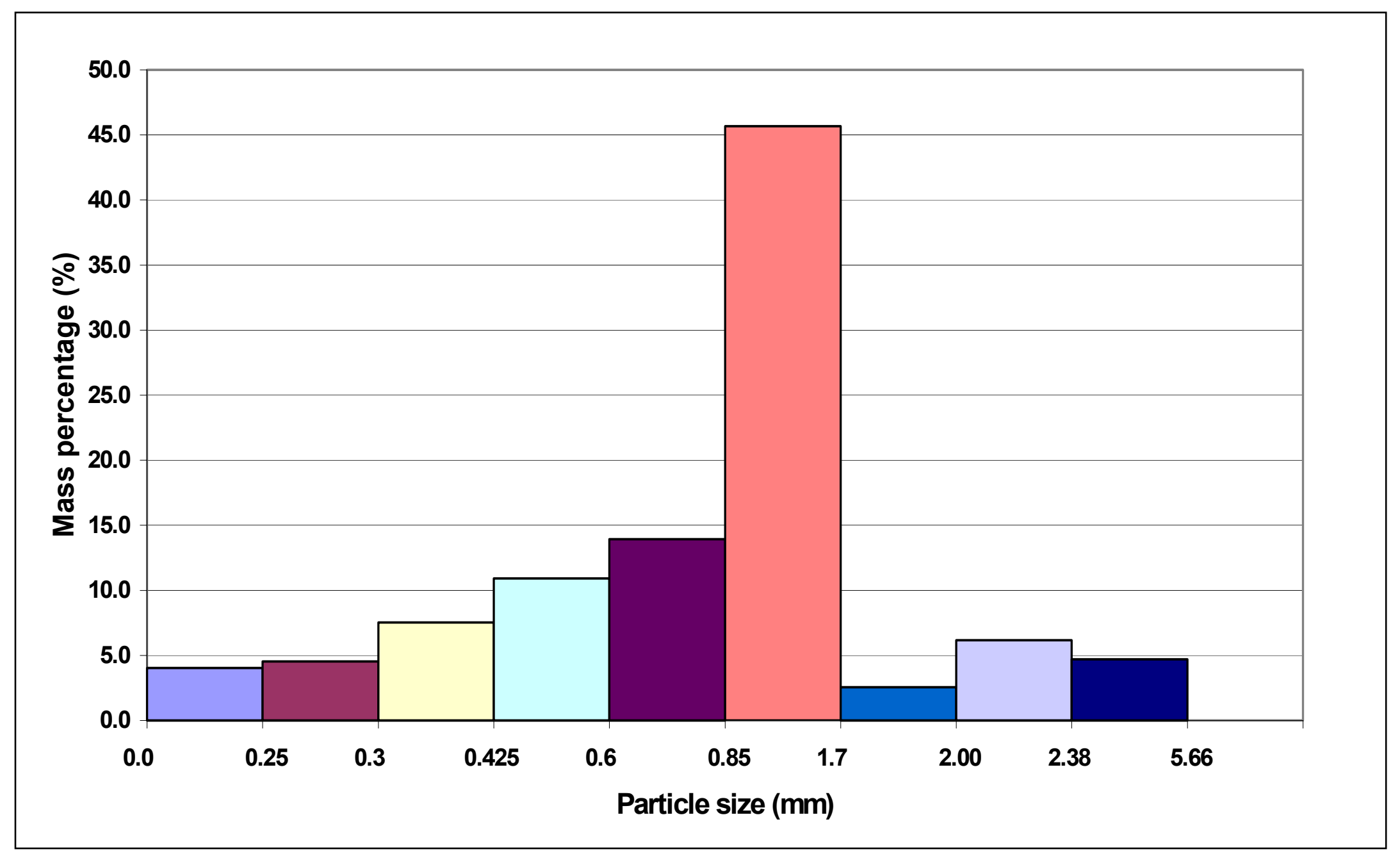


Figure 3. Tiffany Well \#10 Coal Particle Size Distribution

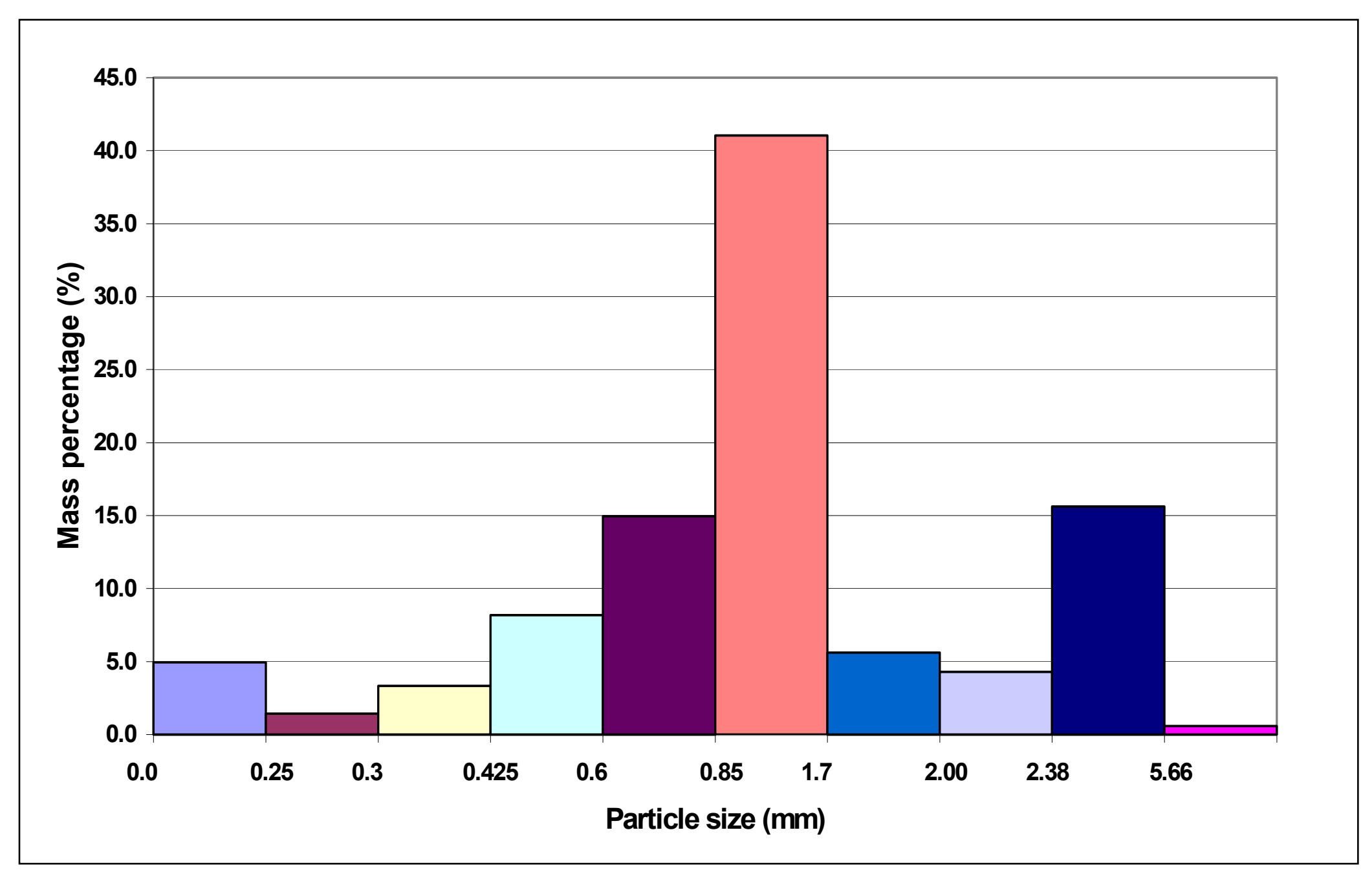


Figure 4. Tiffany Well \#1 and Well \#10 Coal Particle Size Distributions

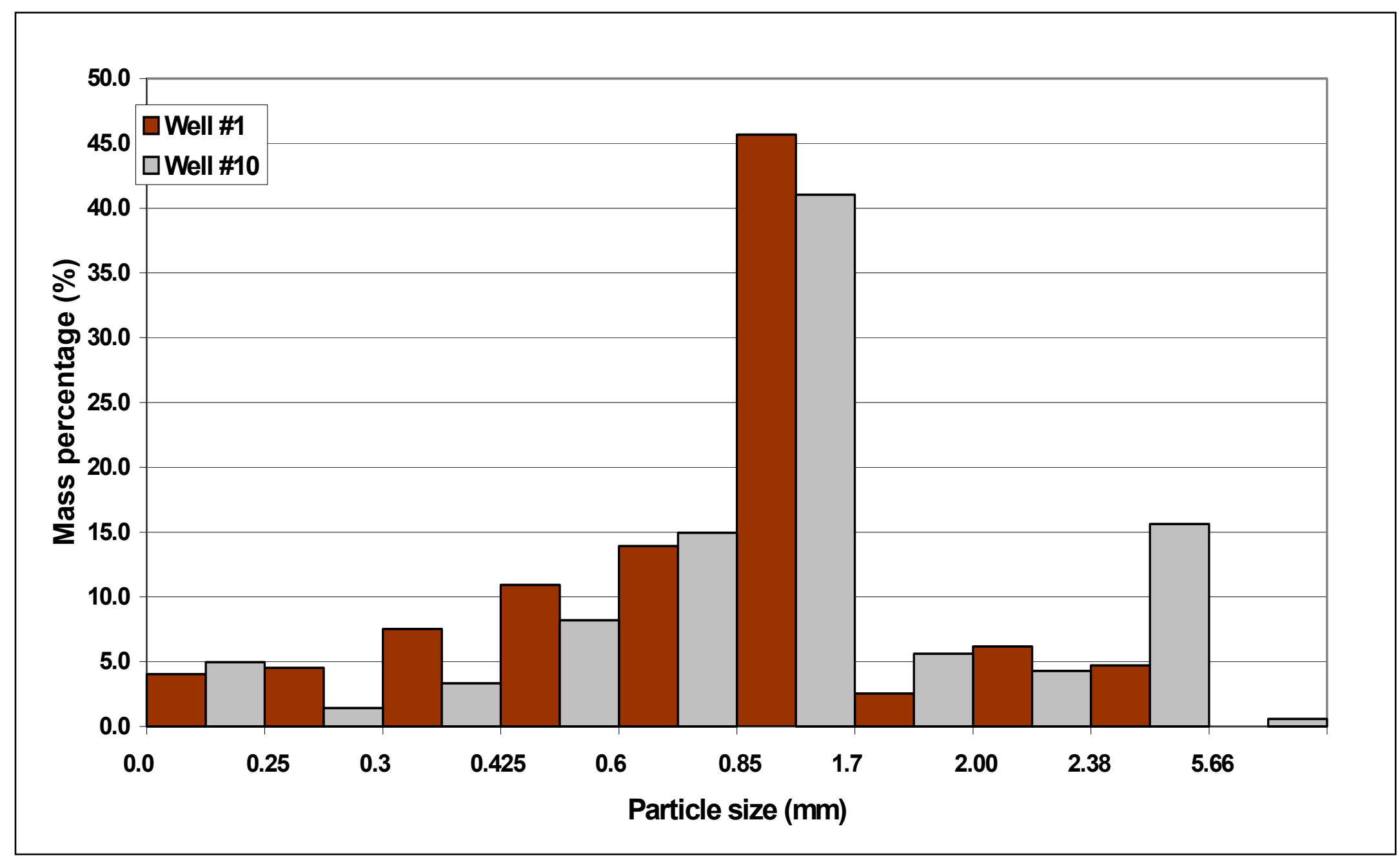


Figure 5. Pure Methane Absolute Adsorption on Tiffany Coal Samples at $130{ }^{\circ} \mathrm{F}$

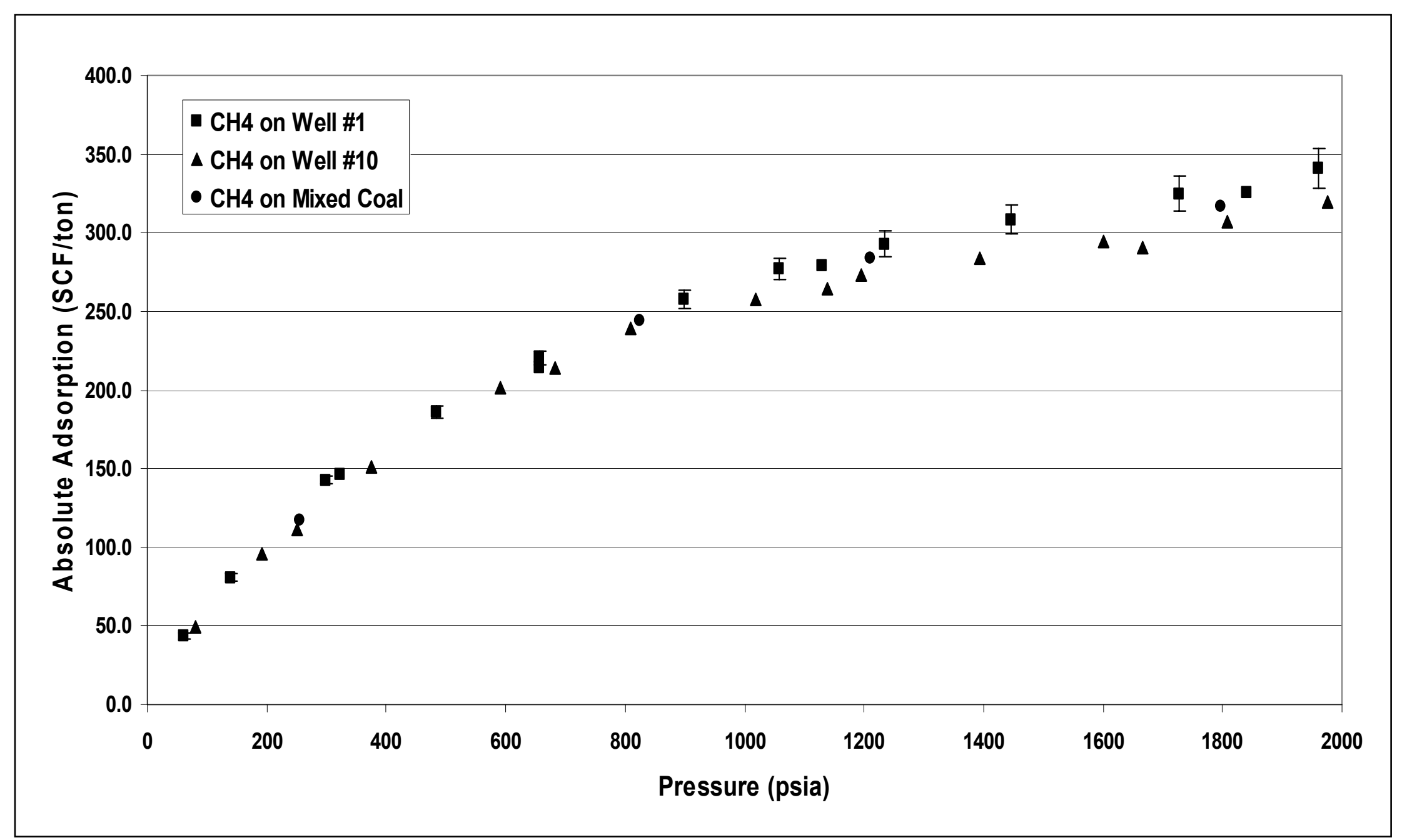


Figure 6. Pure Gas Gibbs Adsorption on Tiffany Coals at $130{ }^{\circ} \mathrm{F}$

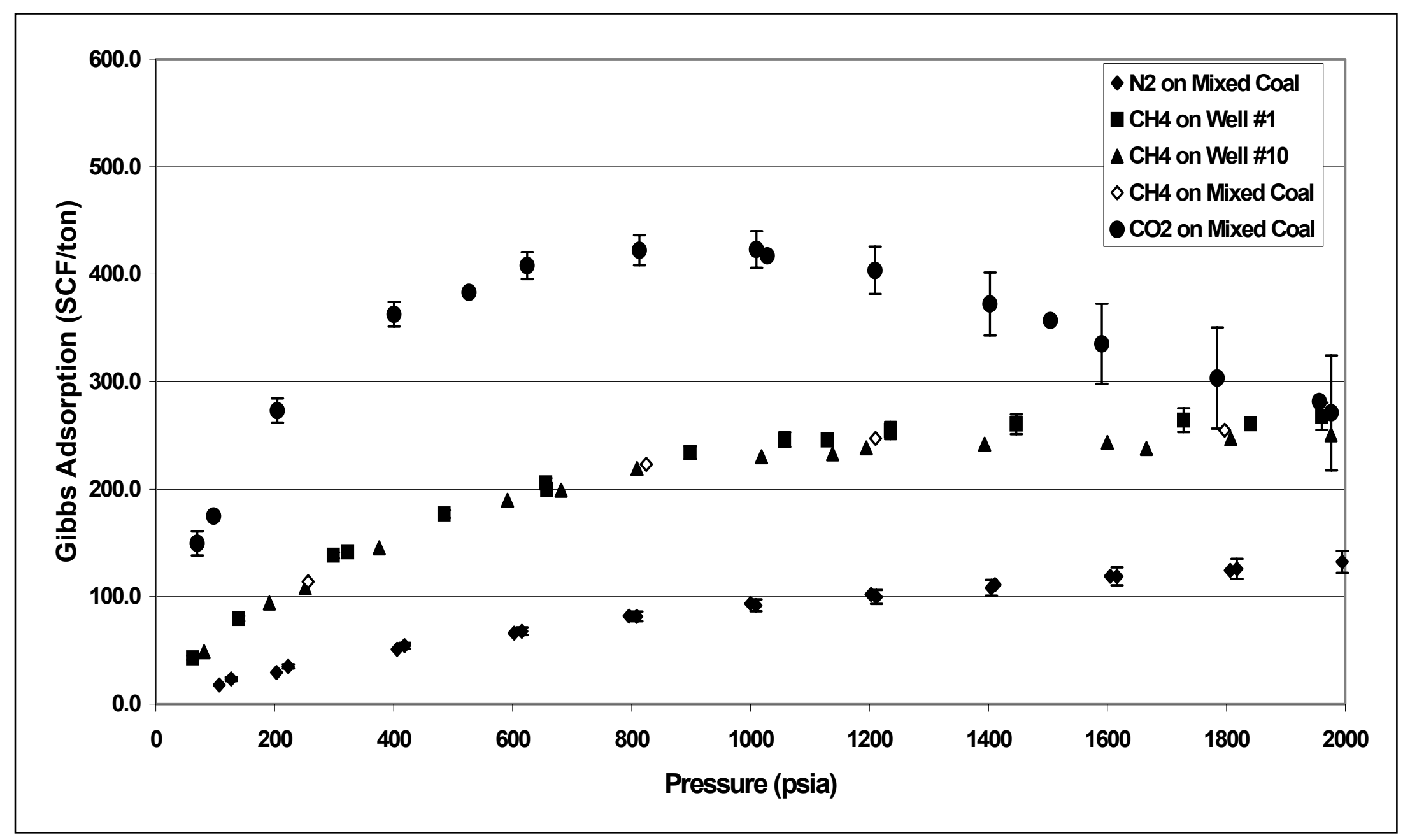


Figure 7. Pure Gas Absolute Adsorption on Tiffany Coals at $130^{\circ} \mathrm{F}$

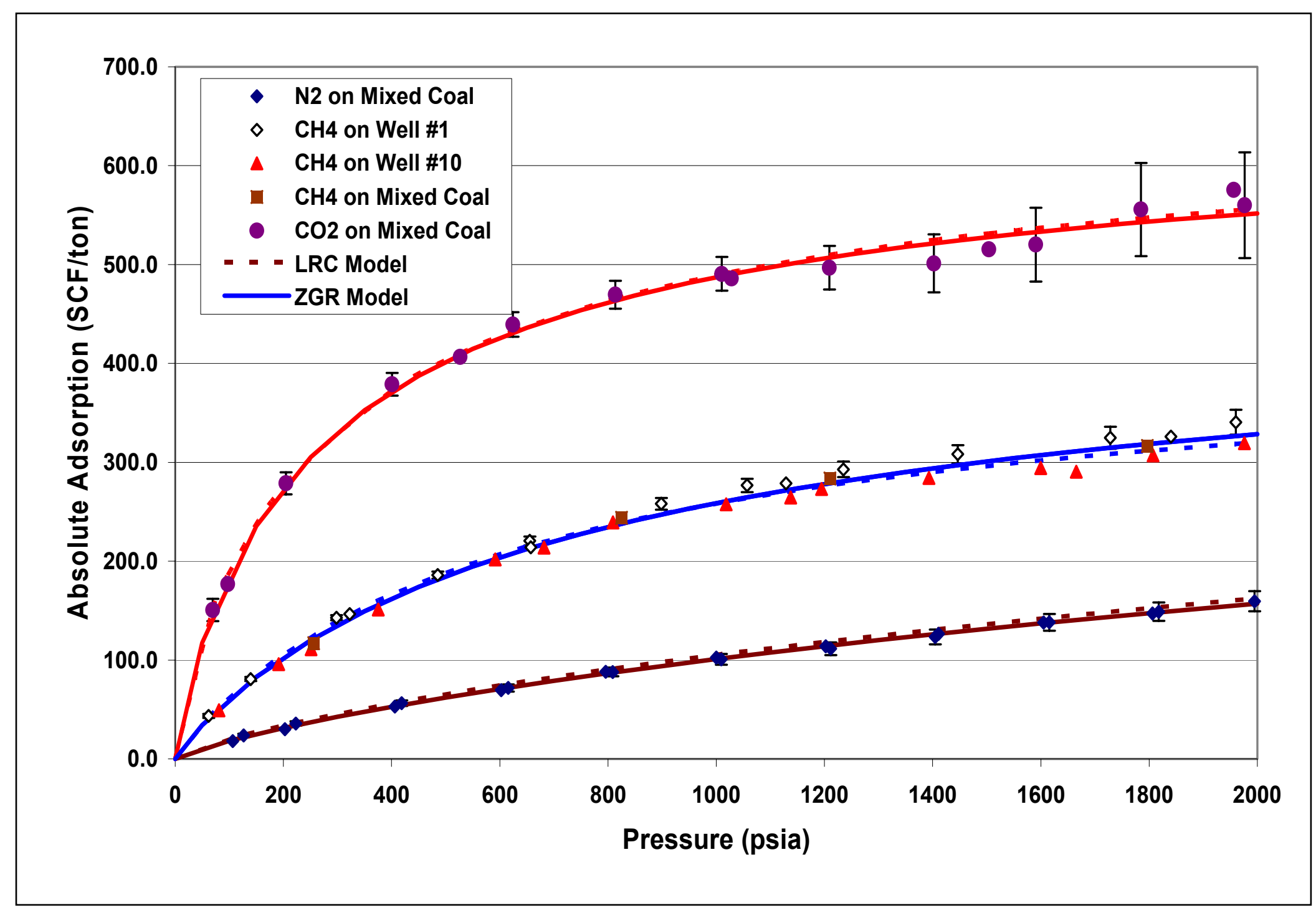


Figure 8. Pure Nitrogen Absolute Adsorption on Tiffany Mixed Coal

Sample at $130^{\circ} \mathrm{F}$

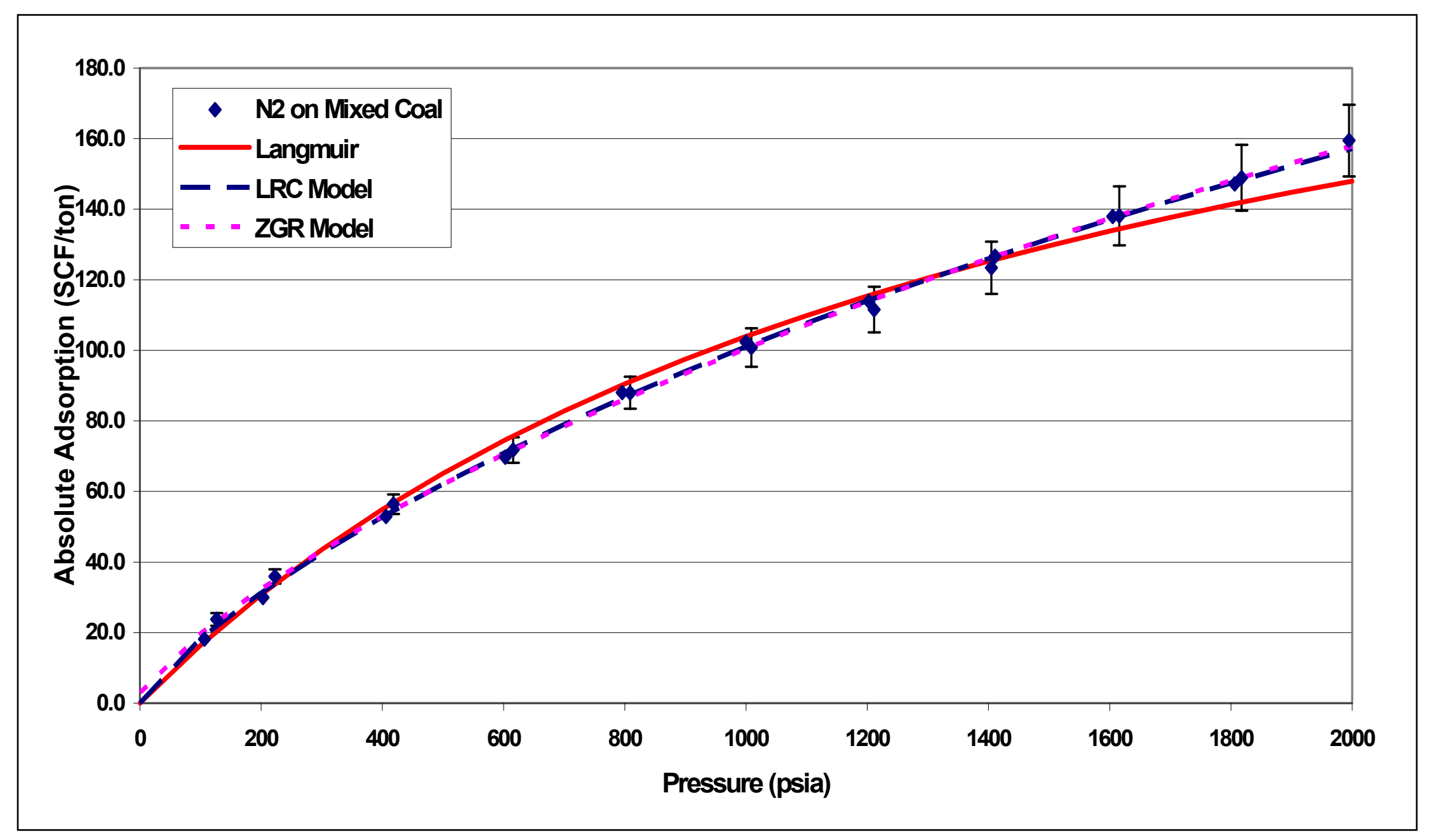


Figure 9. Pure $\mathrm{CO}_{2}$ Absolute Adsorption on Tiffany Mixed Coal

Sample at $130^{\circ} \mathrm{F}$

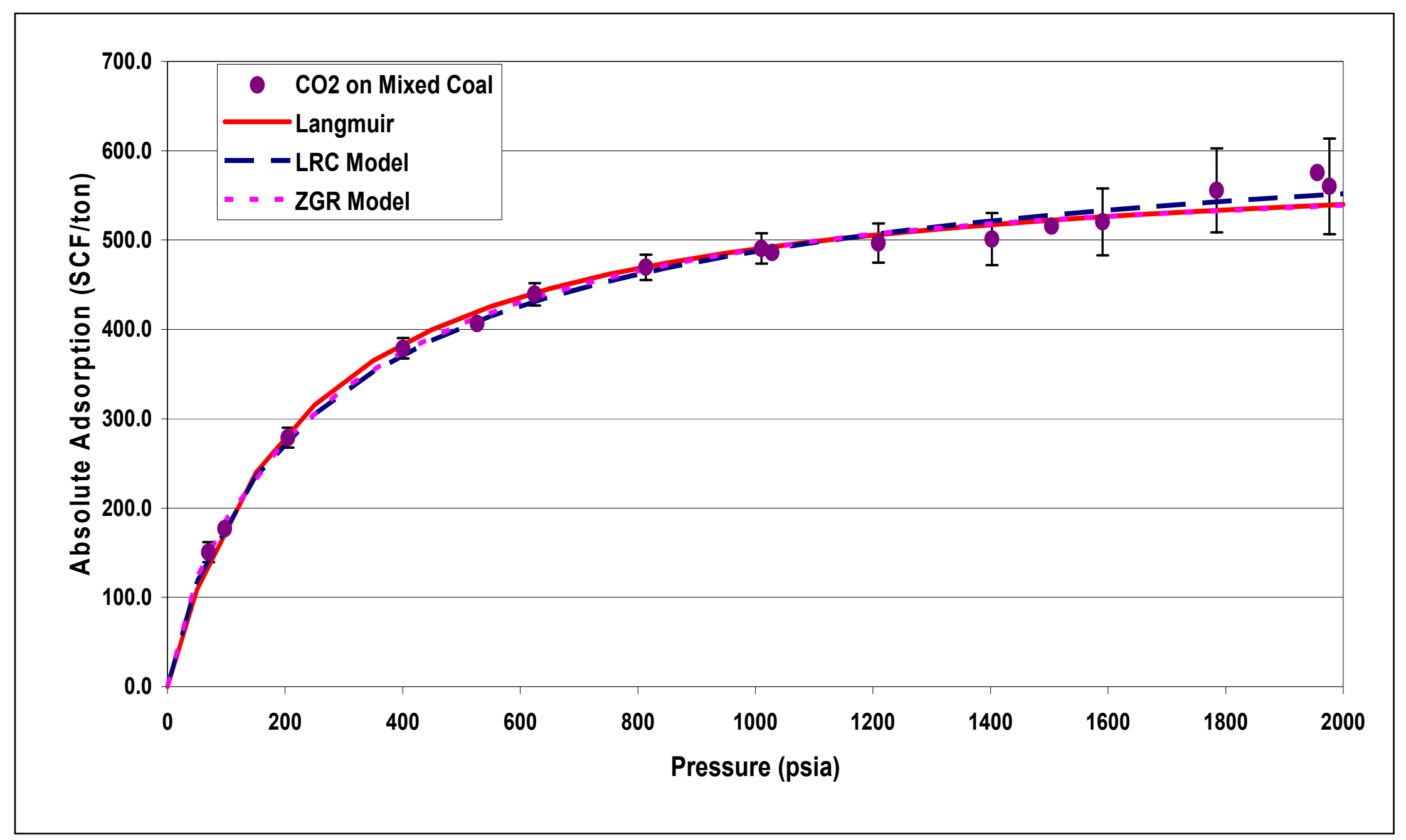


Figure 10. $\mathrm{CO}_{2}$ Absolute Adsorption on Tiffany Mixed Coal Sample Using

Different Adsorbed-Phase Densities

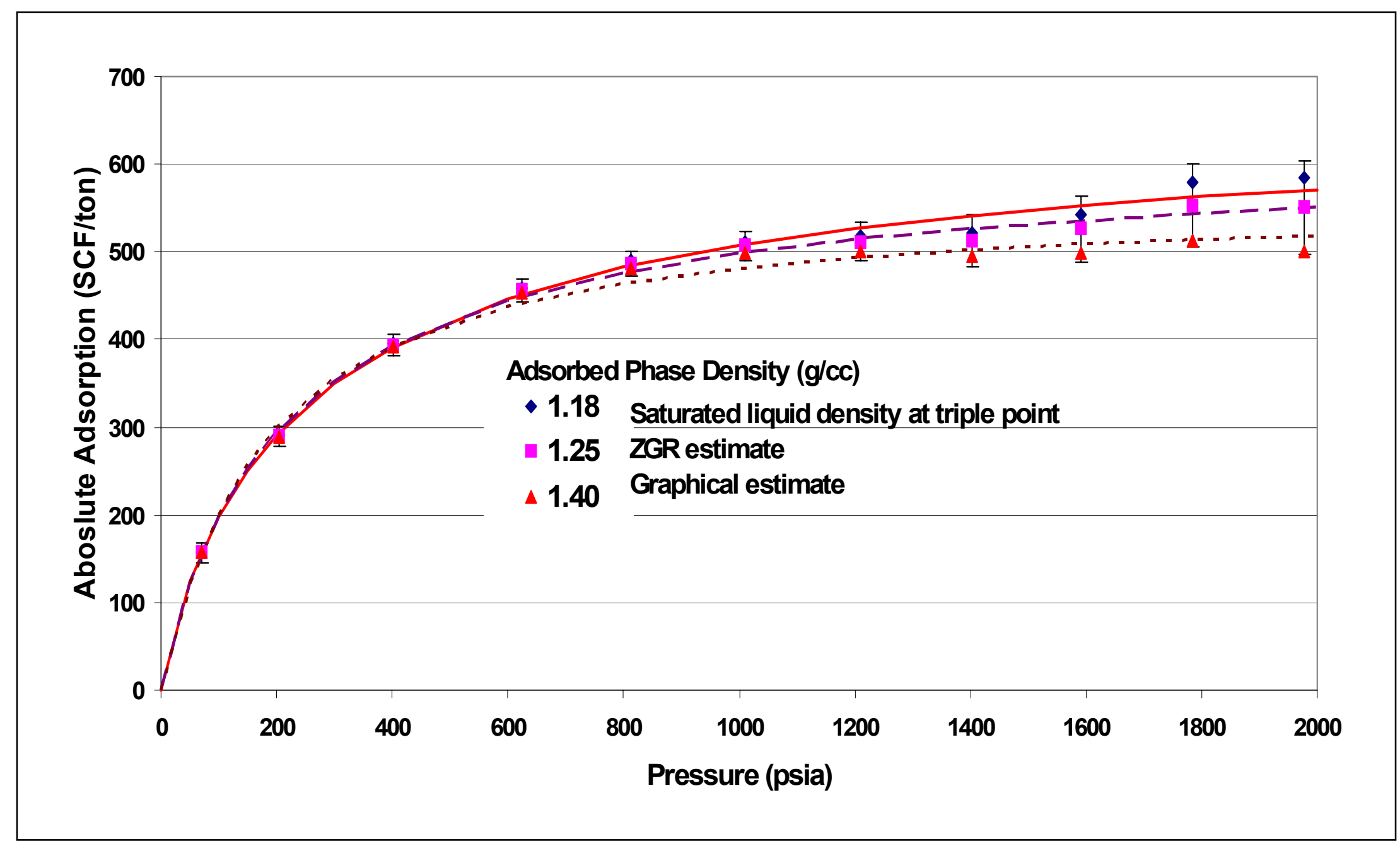


Figure 11. Gibbs Adsorption of a 50/50 Mole \% Methane/Nitrogen Feed Mixture on a Wet Tiffany Mixed Coat Sample at $130^{\circ} \mathrm{F}$

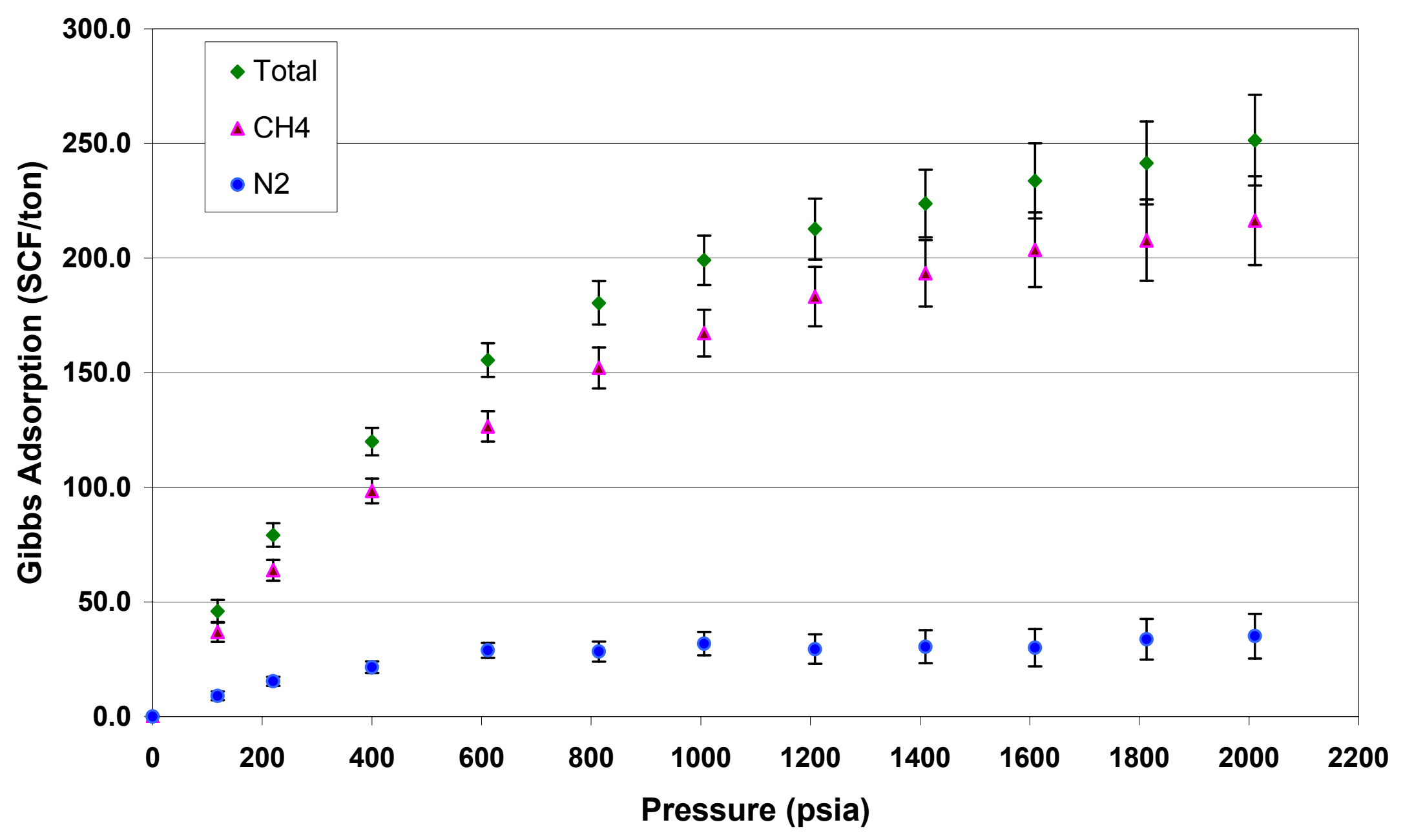


Figure 12. Absolute Adsorption for $50 / 50$ Mole \% Methane/Nitrogen Feed Mixture on a Wet Tiffany Mixed Coal Sample at $130^{\circ} \mathrm{F}$

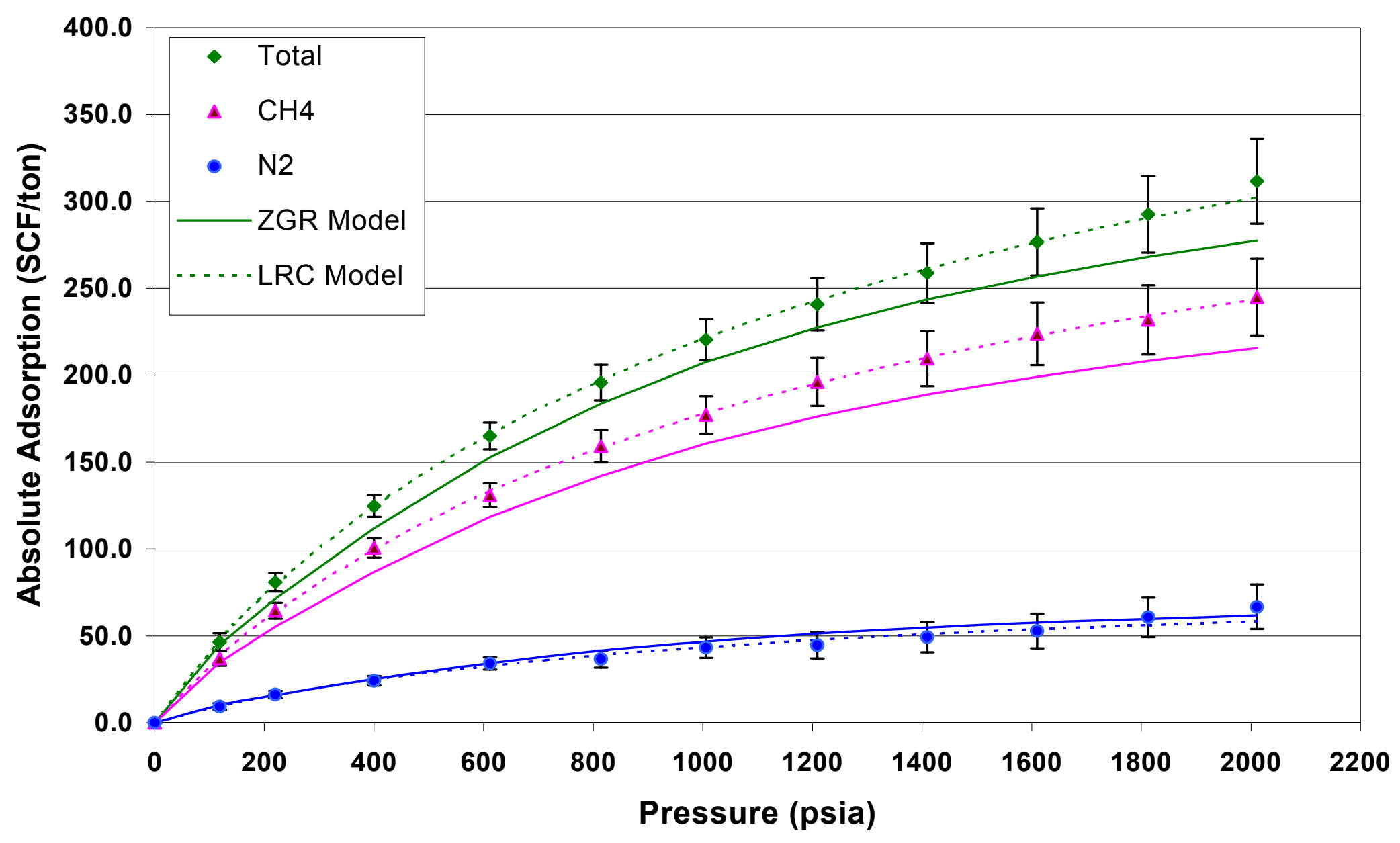


Figure 13. Gibbs Adsorption of a $40 / 60$ Mole $\%$ Methane $/ \mathrm{CO}_{2}$ Feed Mixture on a Wet Tiffany Mixed Coal Sample at $130^{\circ} \mathrm{F}$

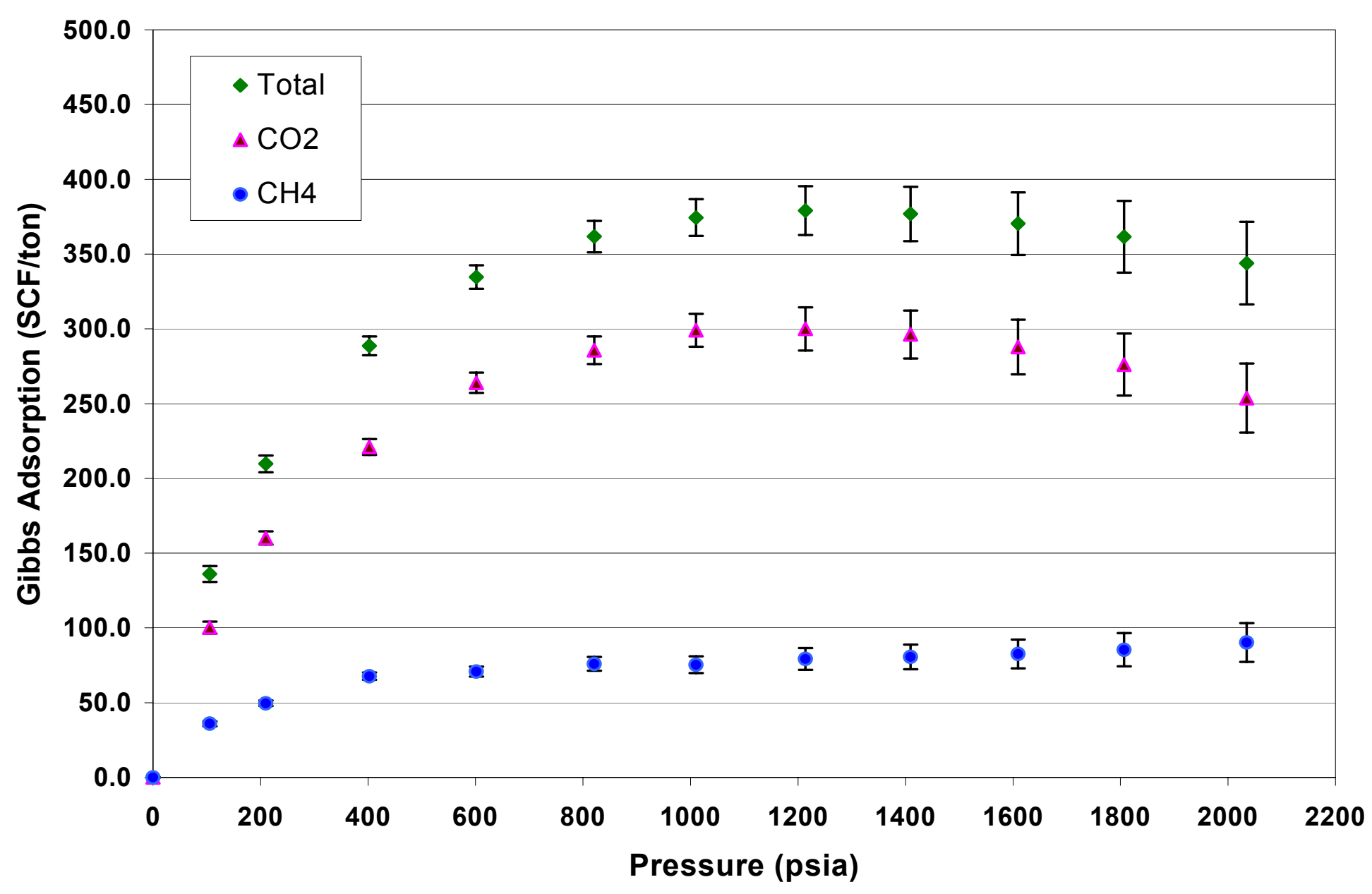


Figure 14. Absolute Adsorption for $40 / 60 \mathrm{Mole} \% \mathrm{Methane} / \mathrm{CO}_{2}$ Feed Mixture on a Wet Tiffany Mixed Coal Sample at $130^{\circ} \mathrm{F}$

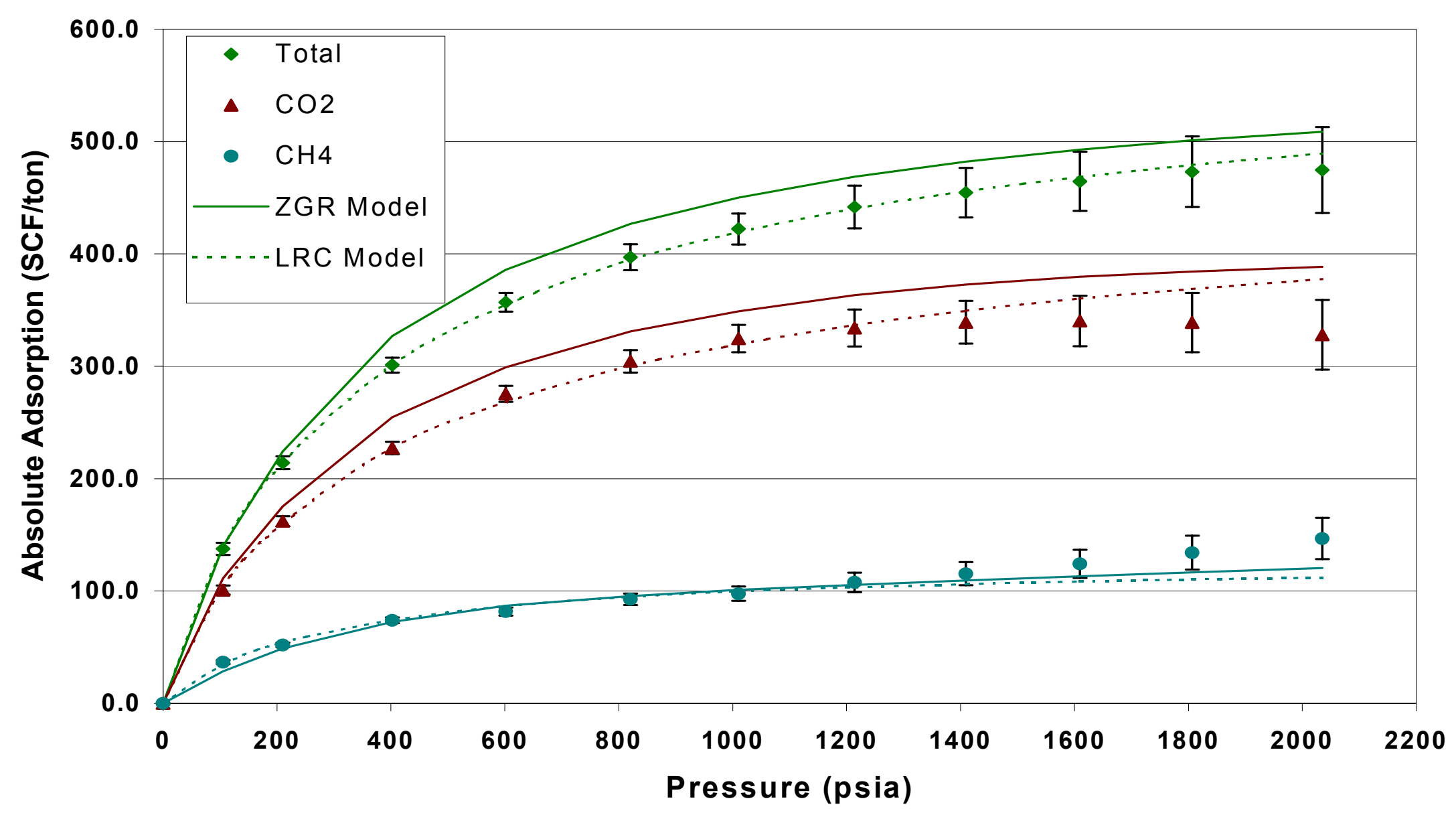


Figure 15. Gibbs Adsorption of a $20 / 80 \mathrm{M}$ ole $\% \mathrm{Nitrogen} / \mathrm{CO}_{2} \mathrm{Feed} \mathrm{Mixture} \mathrm{on} \mathrm{a}$ Wet Tiffany Mixed Coal Sample at $130^{\circ} \mathrm{F}$

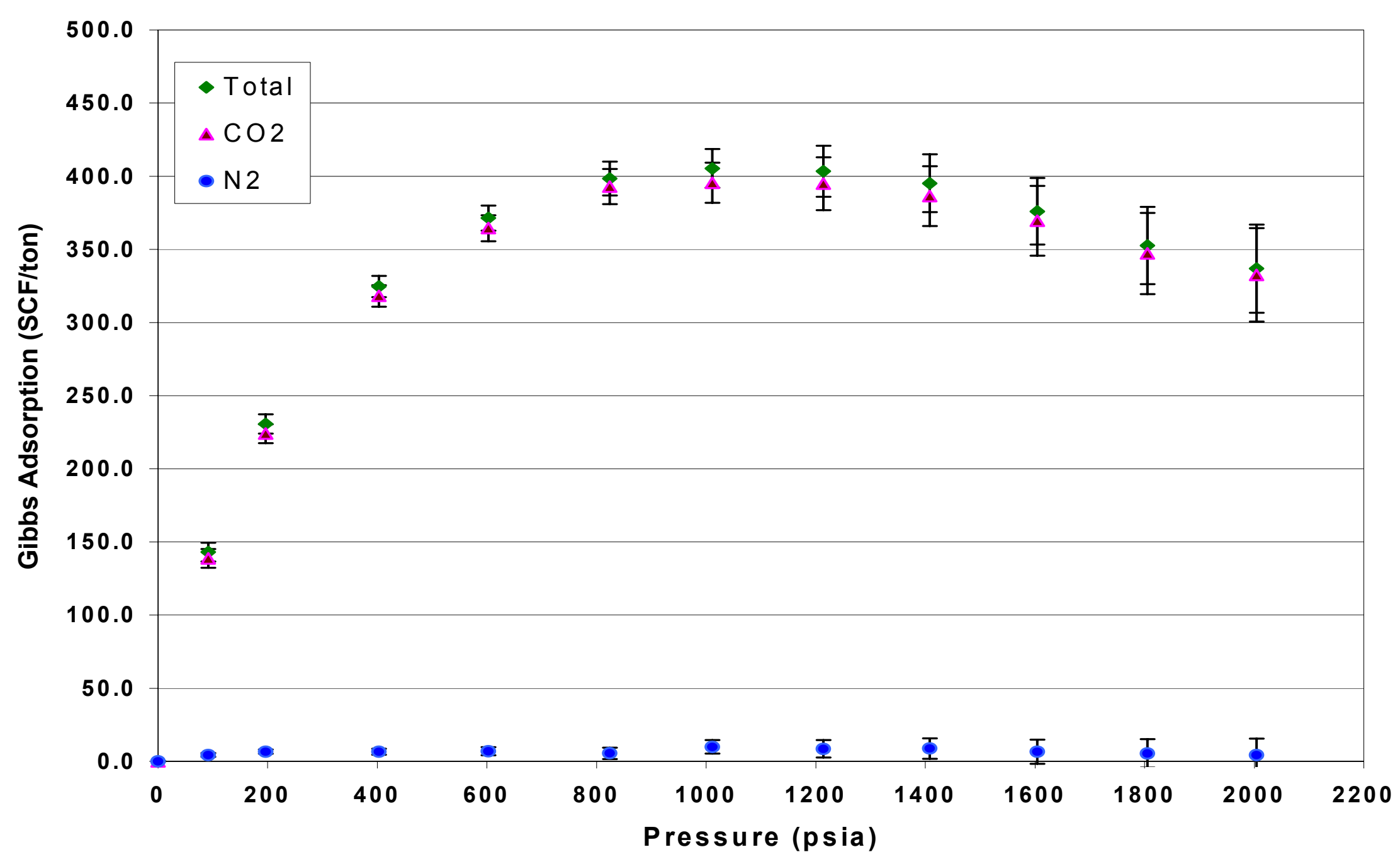


Figure 16. Absolute Adsorption for $20 / 80$ Mole $\%$ Nitrogen $/ \mathrm{CO}_{2}$ Feed Mixture on a Wet Tiffany Mixed Coal Sample at $130^{\circ} \mathrm{F}$

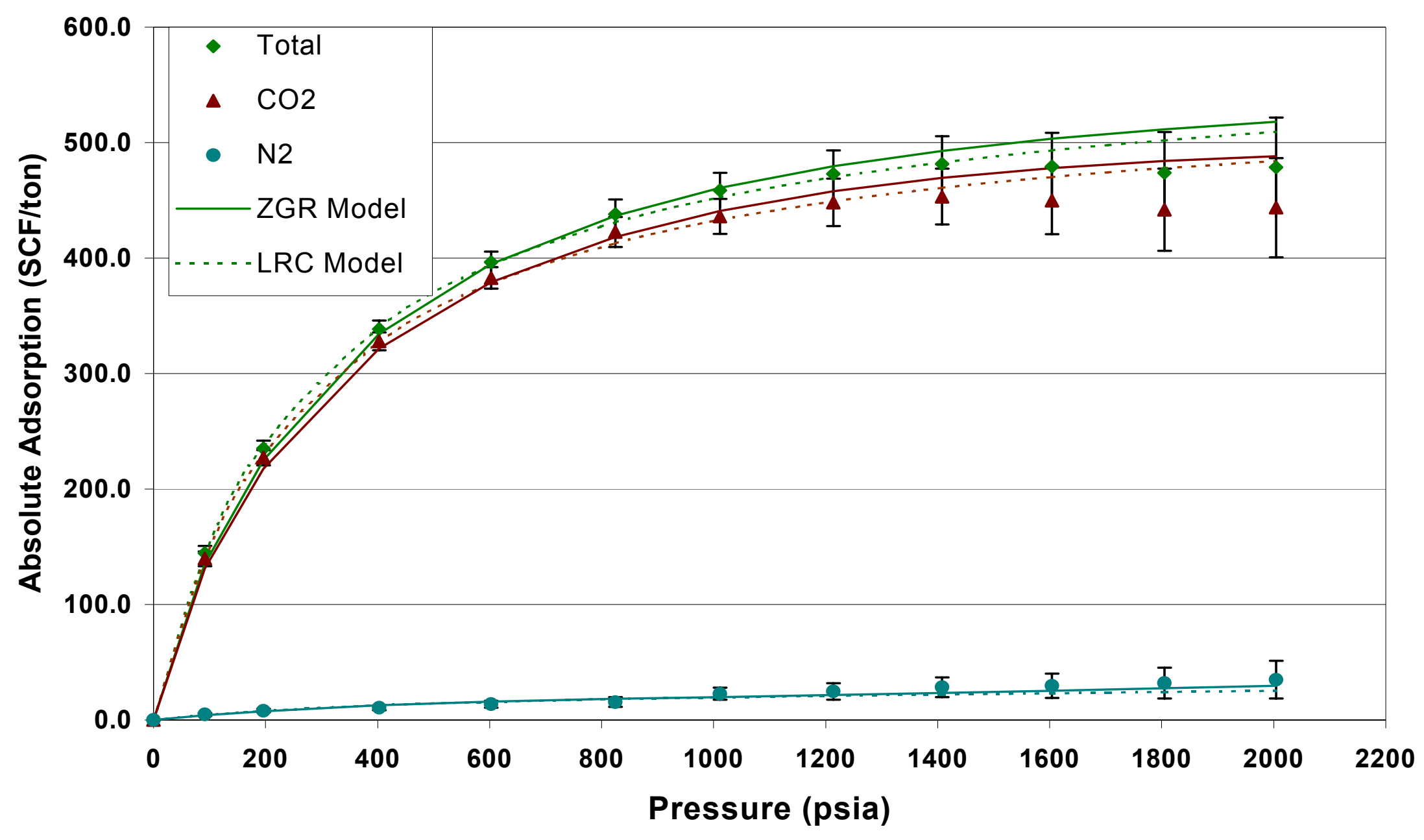


Figure 17. Gibbs Adsorption of a 10/40/50 Mole \% Methane/Nitrogen $/ \mathrm{CO}_{2}$ Feed Mixture on a Wet Tiffany Mixed Coal Sample at $130^{\circ} \mathrm{F}$

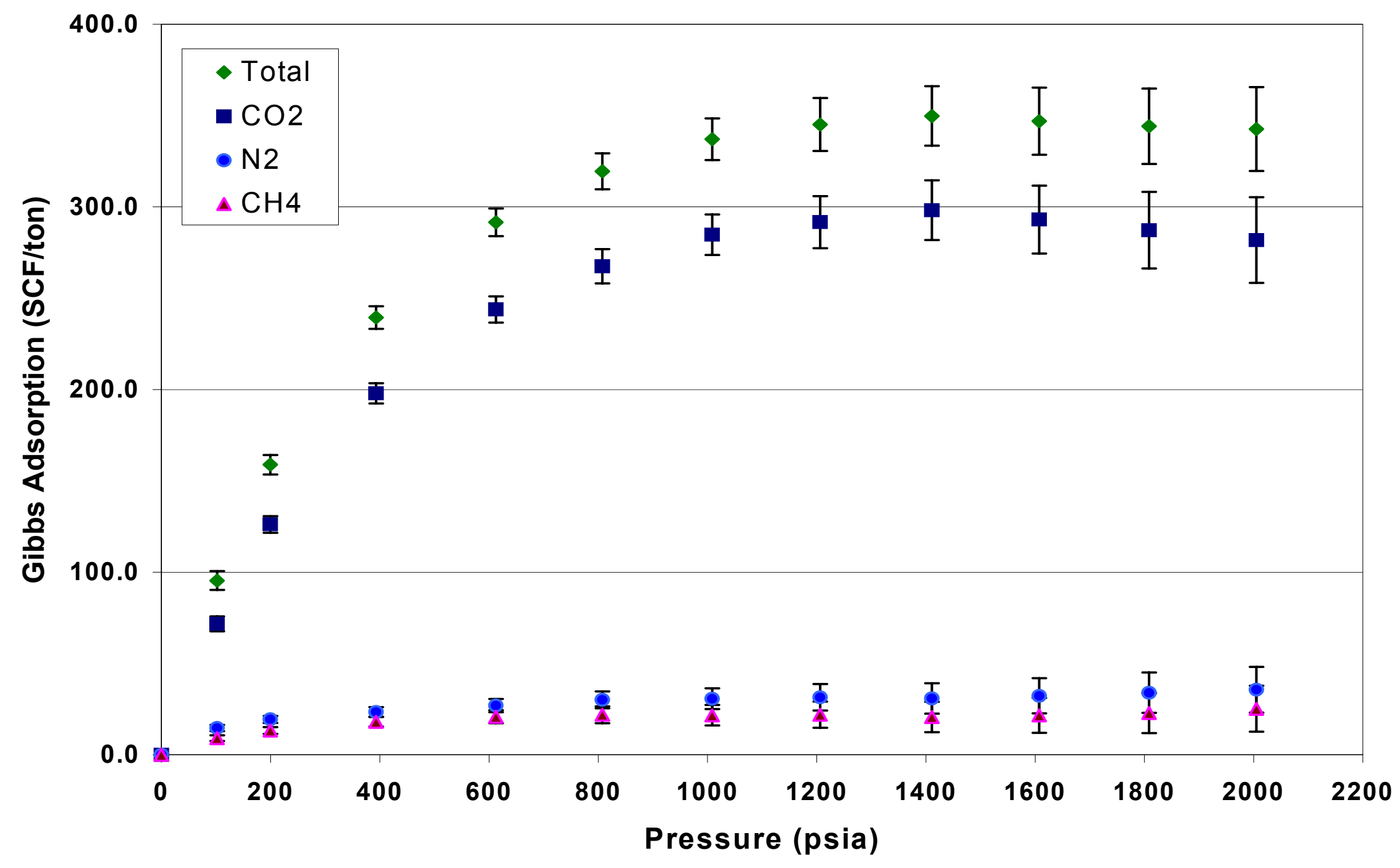


Figure 18. Absolute Adsorption for $10 / 40 / 50$ Mole $\%$ Methane/Nitrogen $/ \mathrm{CO}_{2}$ Feed on Wet Tiffany Mixed Coal Sample at $130{ }^{\circ} \mathrm{F}$

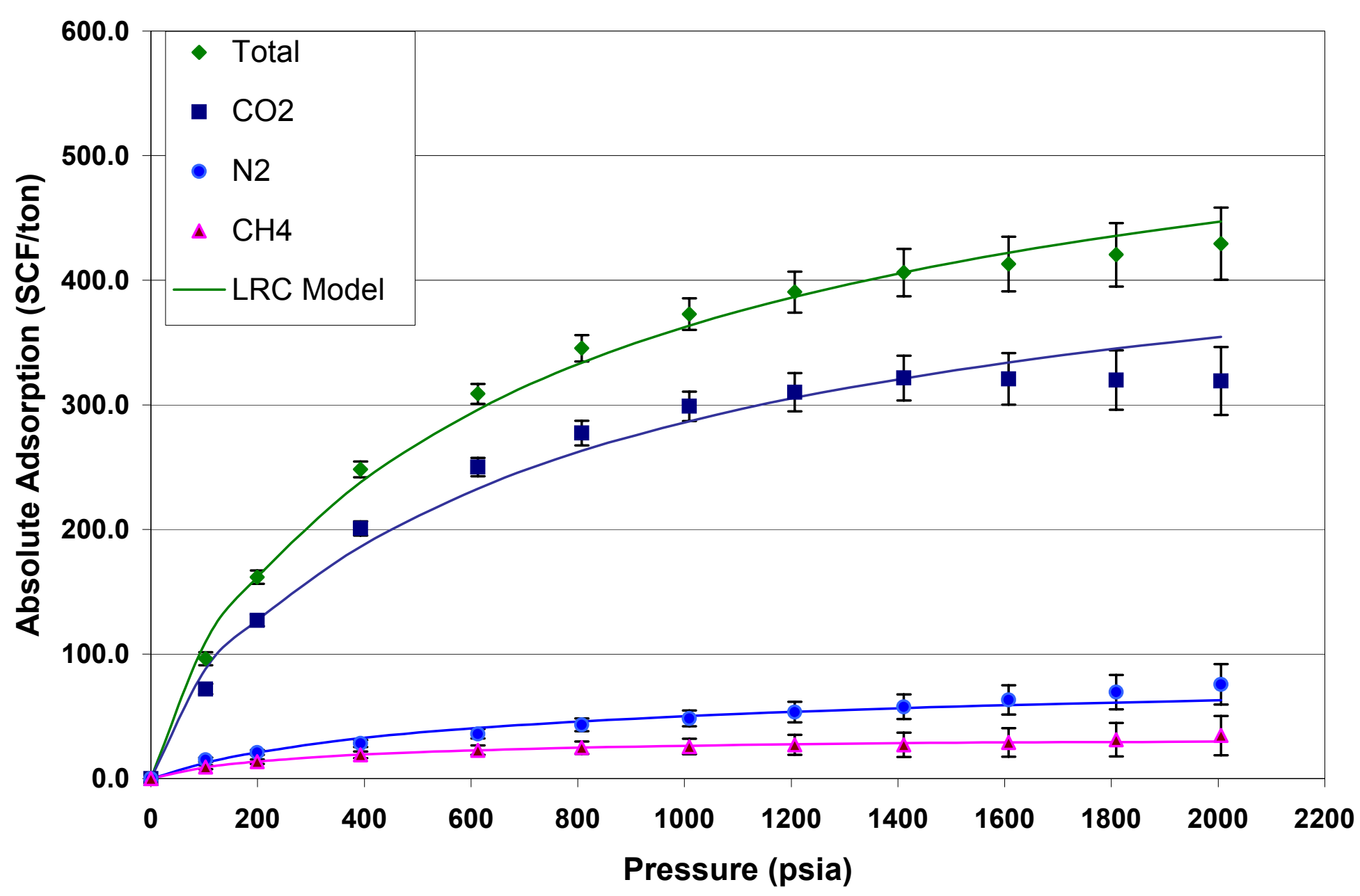


Figure 19. Fractional Uptake of Methane Desorption on Tiffany Well \#1

\section{Coal at $130{ }^{\circ} \mathrm{F}$}

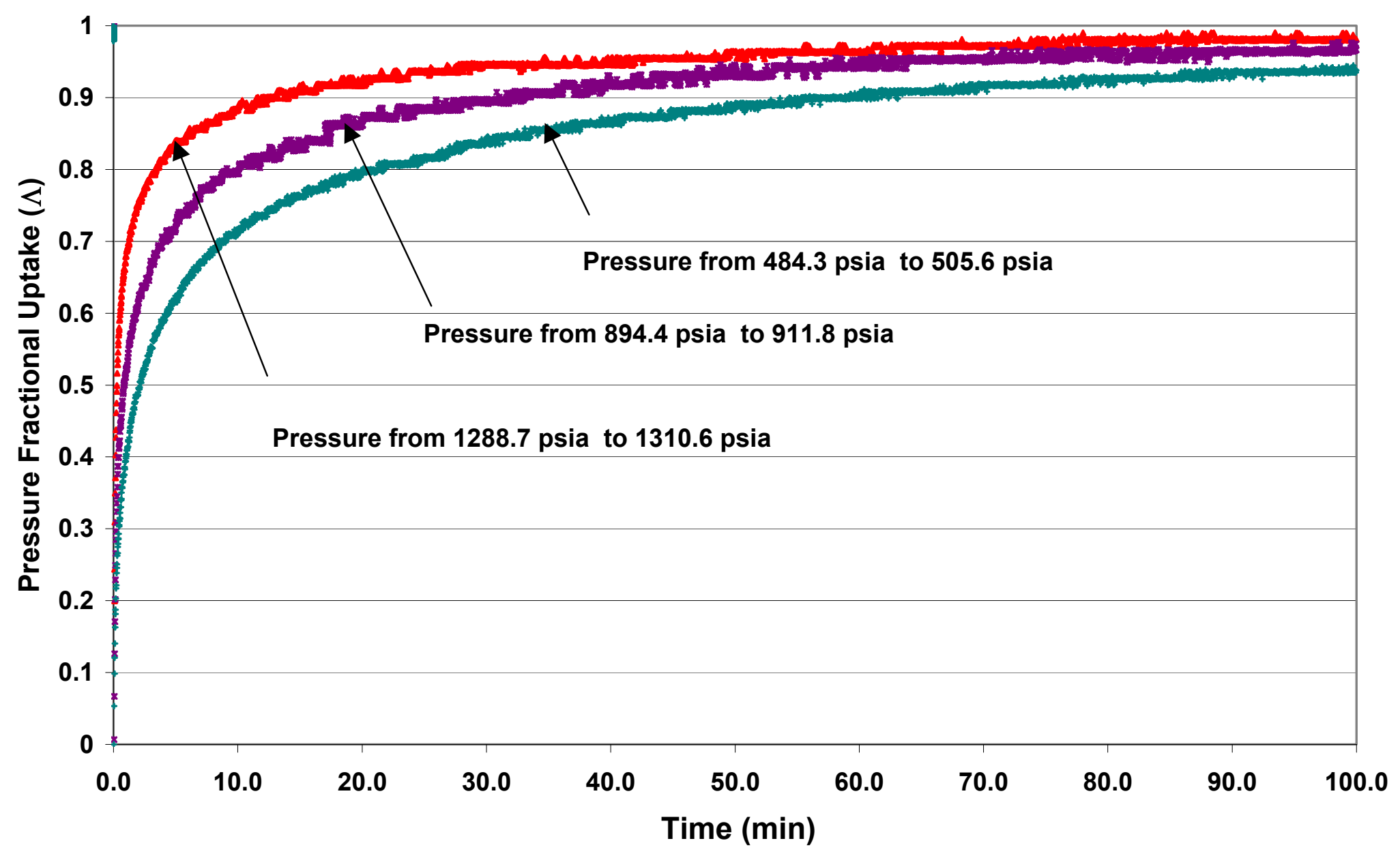


Figure 20. Fractional Uptake of Methane Desorption on Tiffany Well \#10 Coal at $130{ }^{\circ} \mathrm{F}$

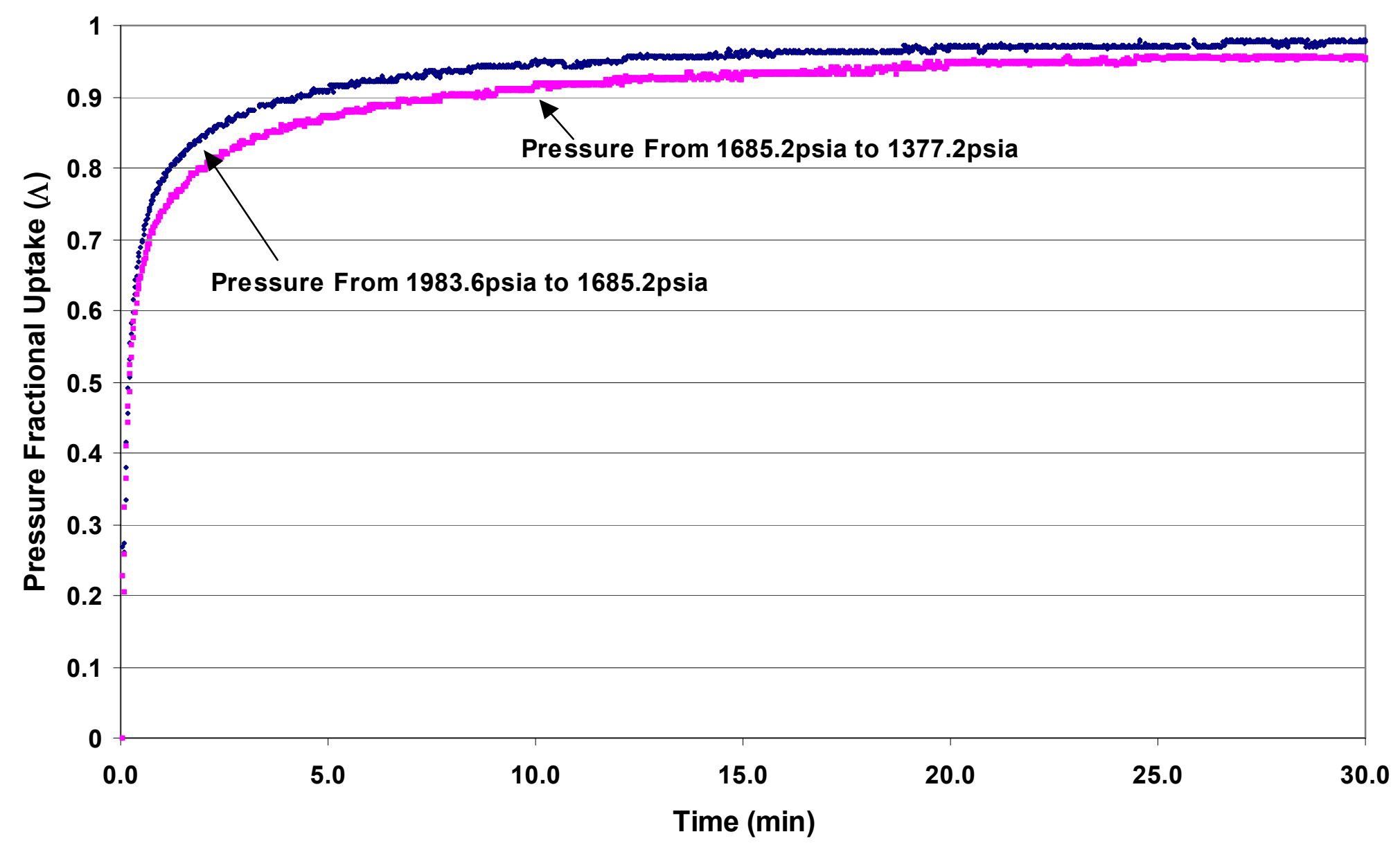


Figure 21. Fractional Uptake of Nitrogen on Tiffany Mixed Coal

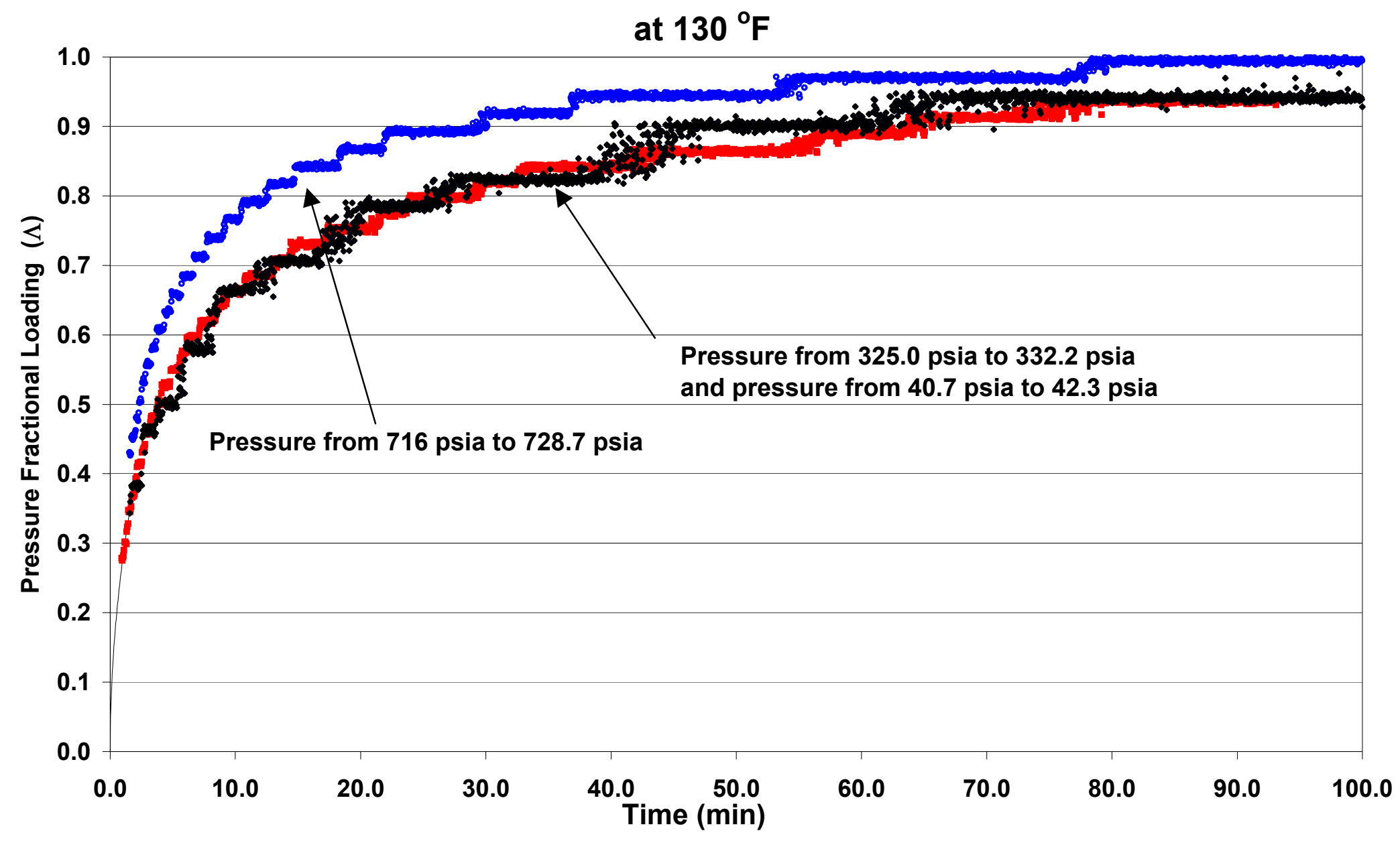


Figure 22. Fractional Uptake of $\mathrm{CO}_{2}$ Adsorption on Tiffany Mixed Coal at $130^{\circ} \mathrm{F}$

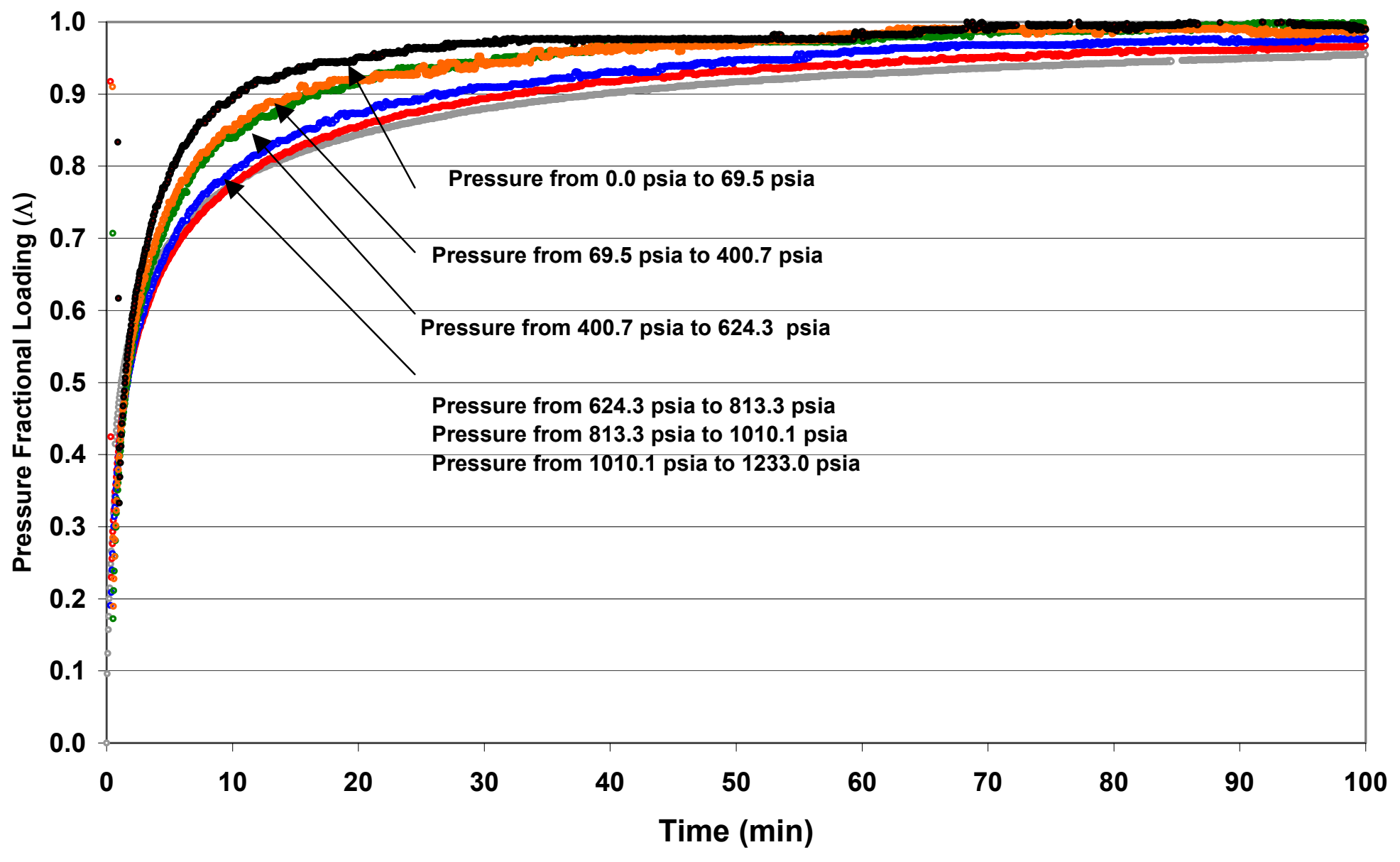


Figure 23. Model Predictions of Absolute Adsorption for $50 / 50$ Mole $\%$ Methane/Nitrogen Feed Mixture on a Wet Tiffany Mixed Coal Sample at $130{ }^{\circ} \mathrm{F}$

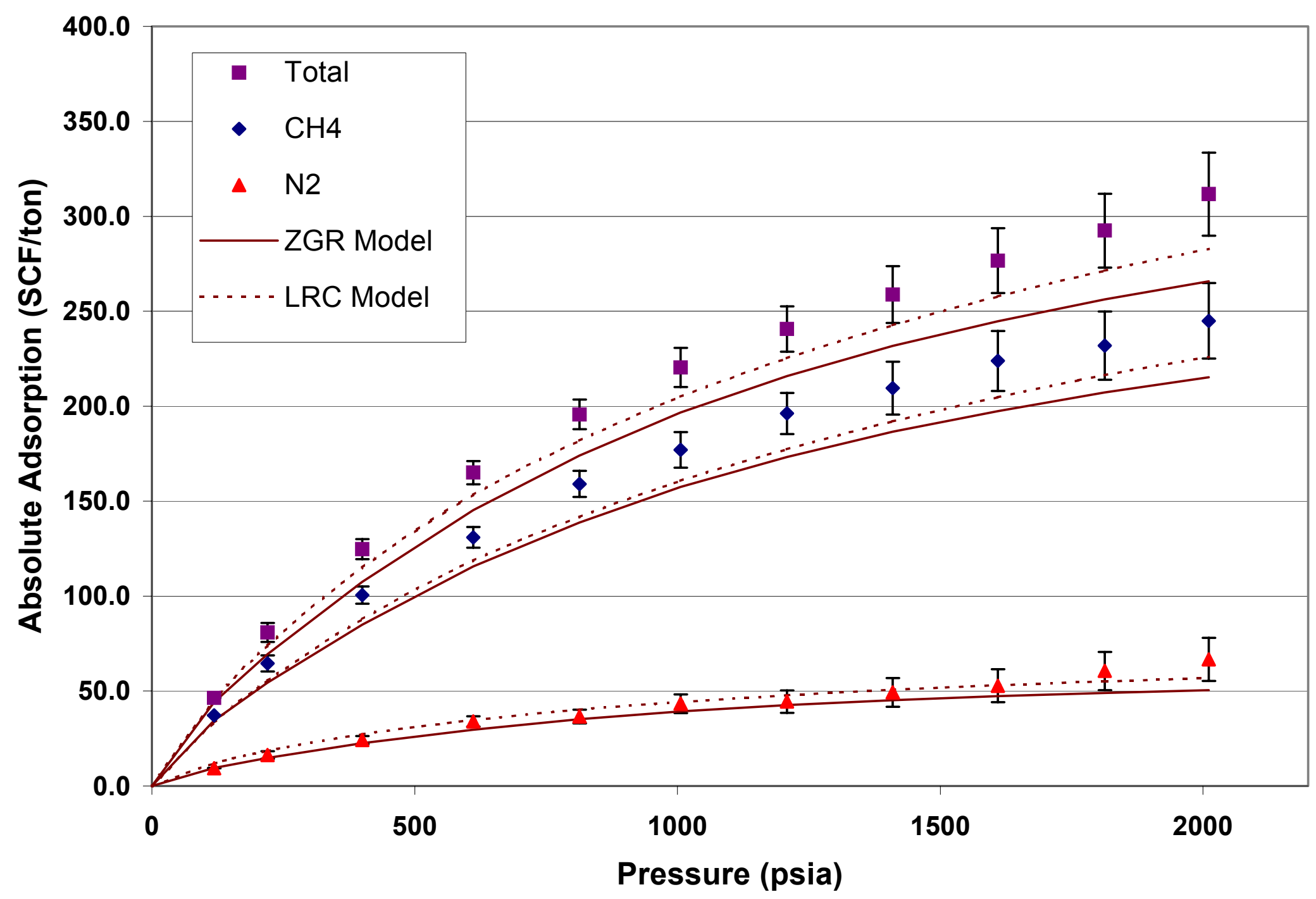


Figure 24. Model Predictions of Absolute Adsorption for $40 / 60 \mathrm{Mole} \%$ Methane/ $\mathrm{CO}_{2}$ Feed Mixture on a Wet Tiffany Mixed Coal Sample at $130{ }^{\circ} \mathrm{F}$

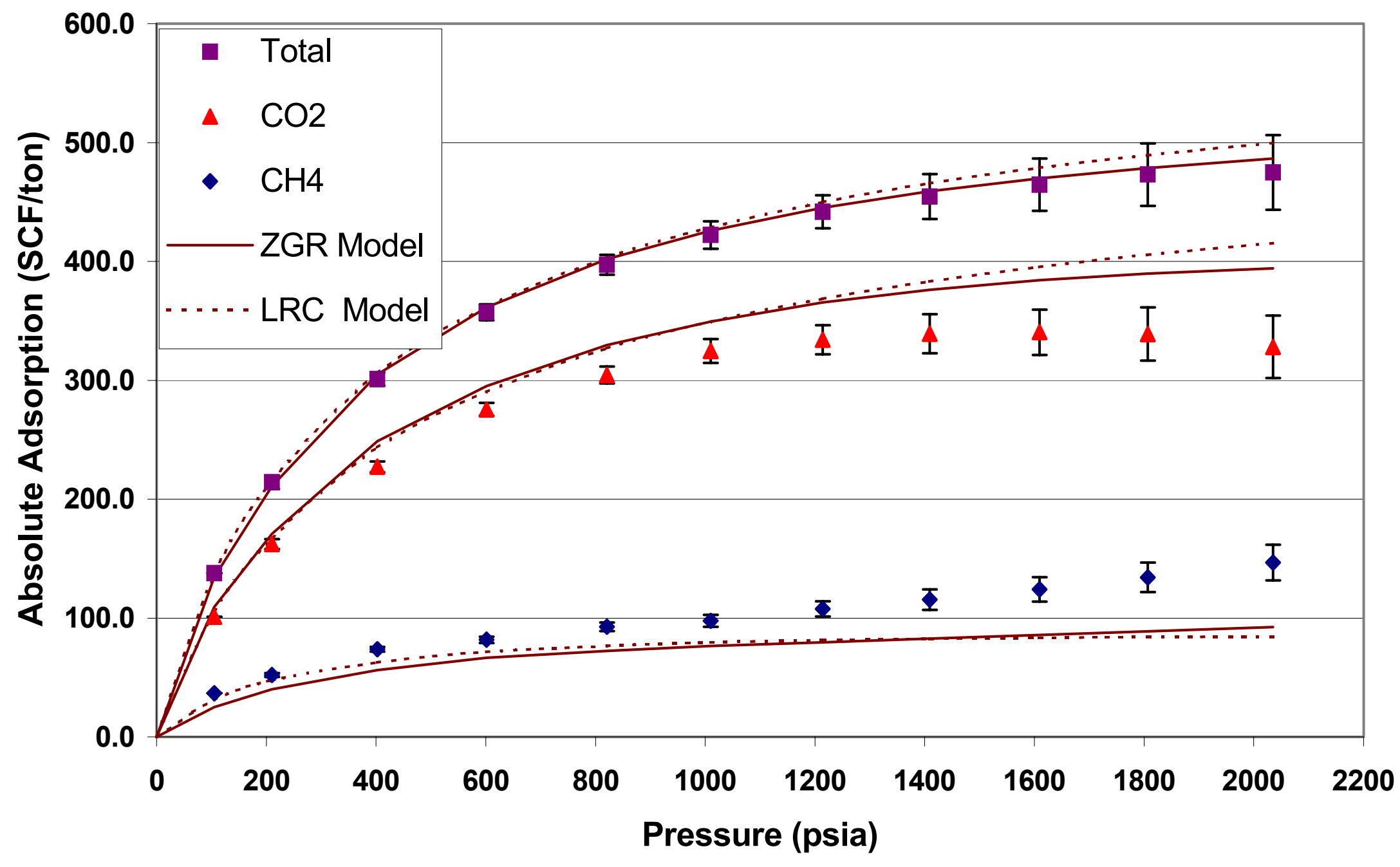


Figure 25. Model Predictions of Absolute Adsorption for 20/80 Mole \% Nitrogen $/ \mathrm{CO}_{2}$ Feed Mixture on a Wet Tiffany Mixed Coal Sample at $130^{\circ} \mathrm{F}$

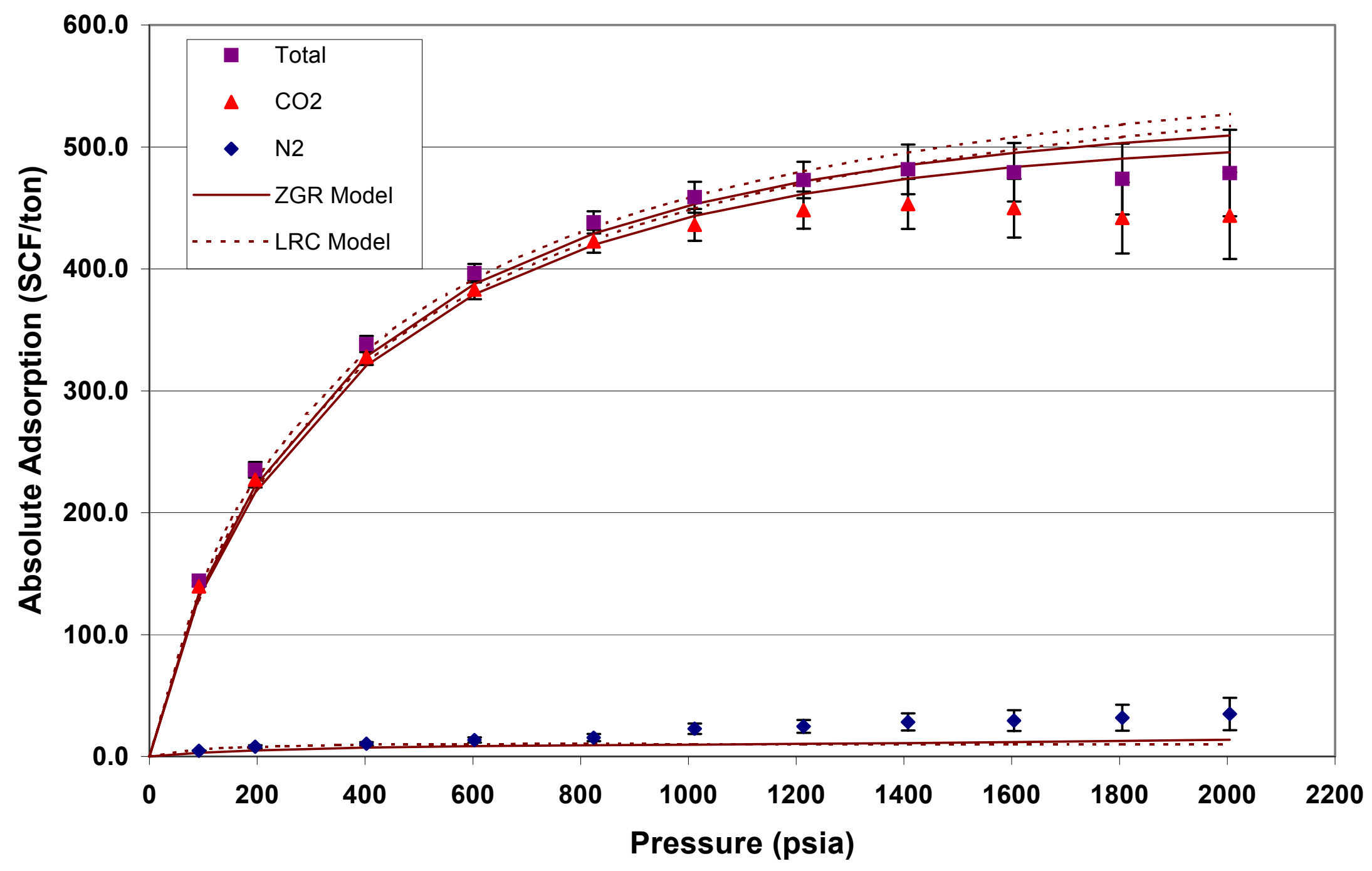


Figure 26 Model Predictions of Absolute Adsorption for 10/40/50 Mole \% Methane/Nitrogen $/ \mathrm{CO}_{2}$ Feed on a Wet Tiffany Mixed Coal Sample at $130{ }^{\circ} \mathrm{F}$

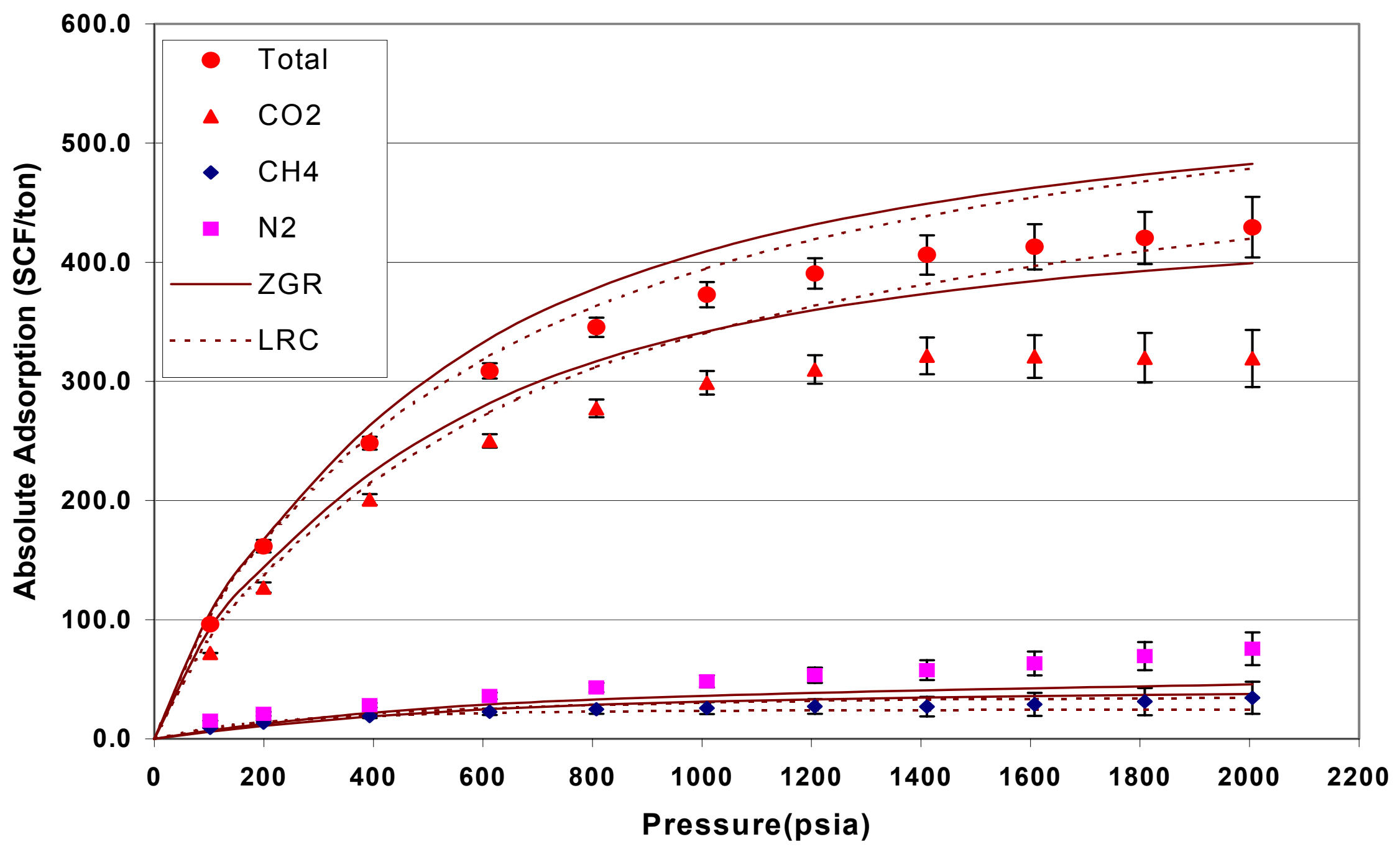


Figure 27. Desorption Curve for Methane on Tiffany Well \#1 Coal at $130{ }^{\circ} \mathrm{F}$

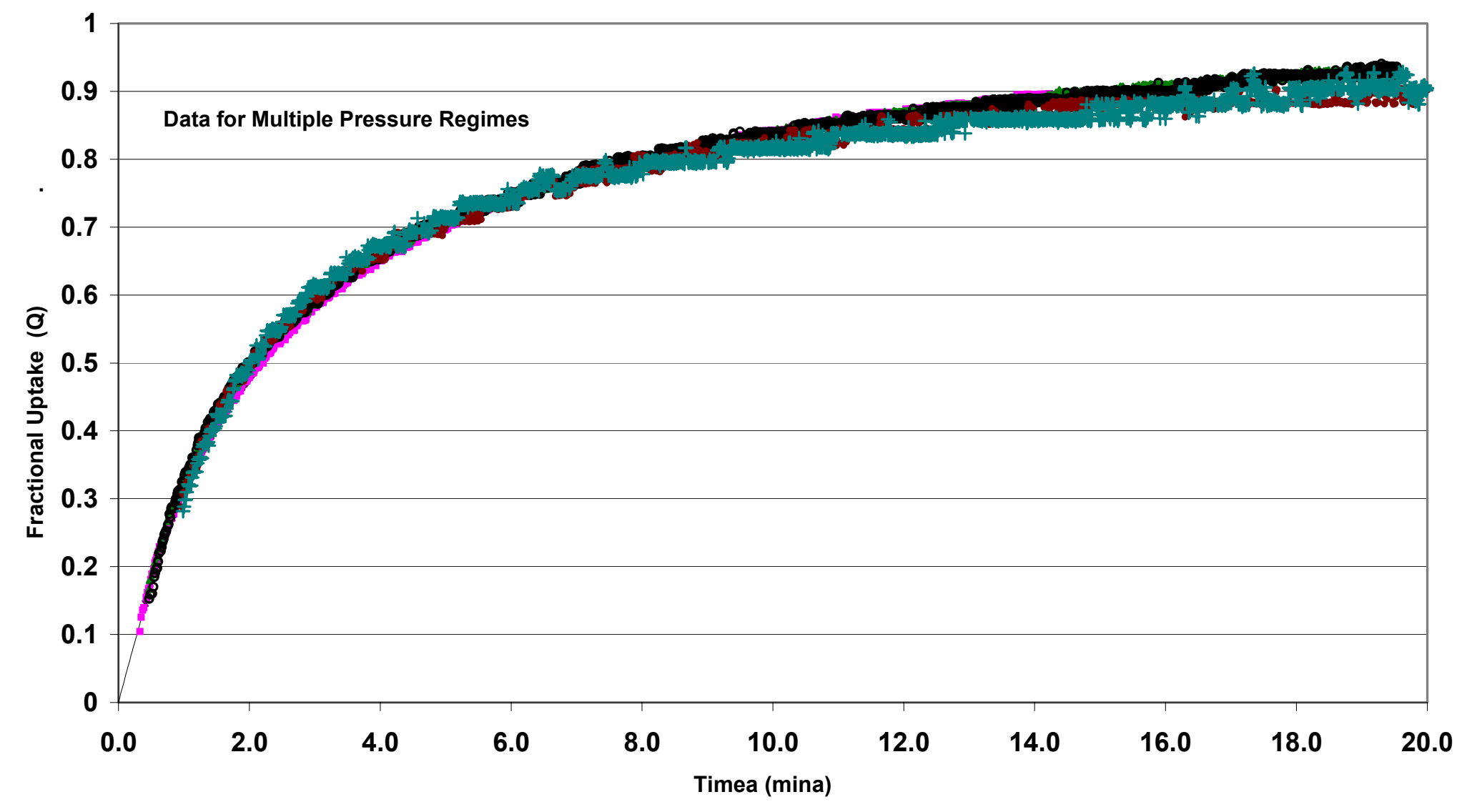


Figure 28. Desorption Curve for Methane on Tiffany Well \#10 Coal at $130{ }^{\circ} \mathrm{F}$

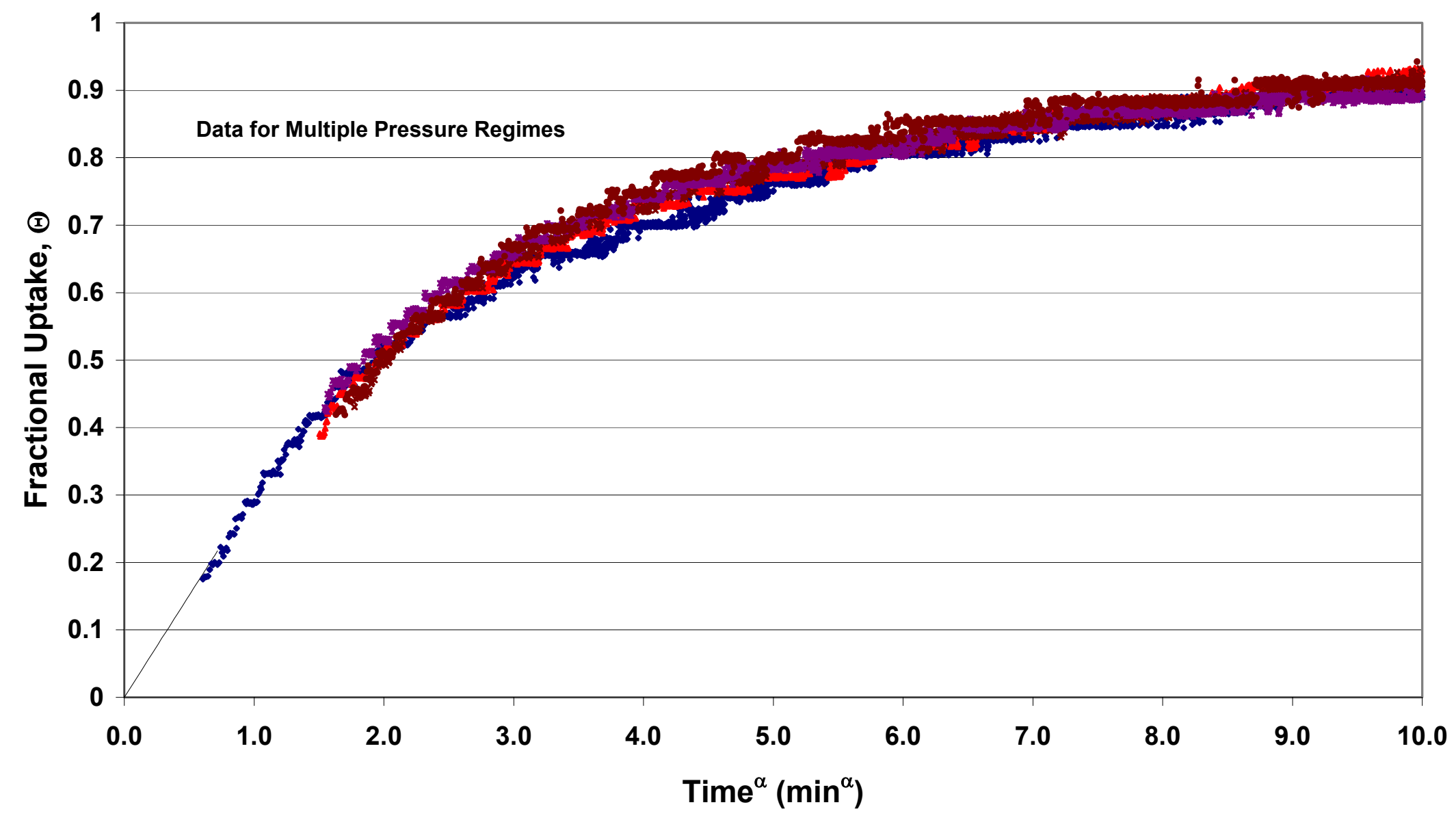


Figure 29. Desorption Curve for Nitrogen on Tiffany Mixed Coal at $130{ }^{\circ} \mathrm{F}$

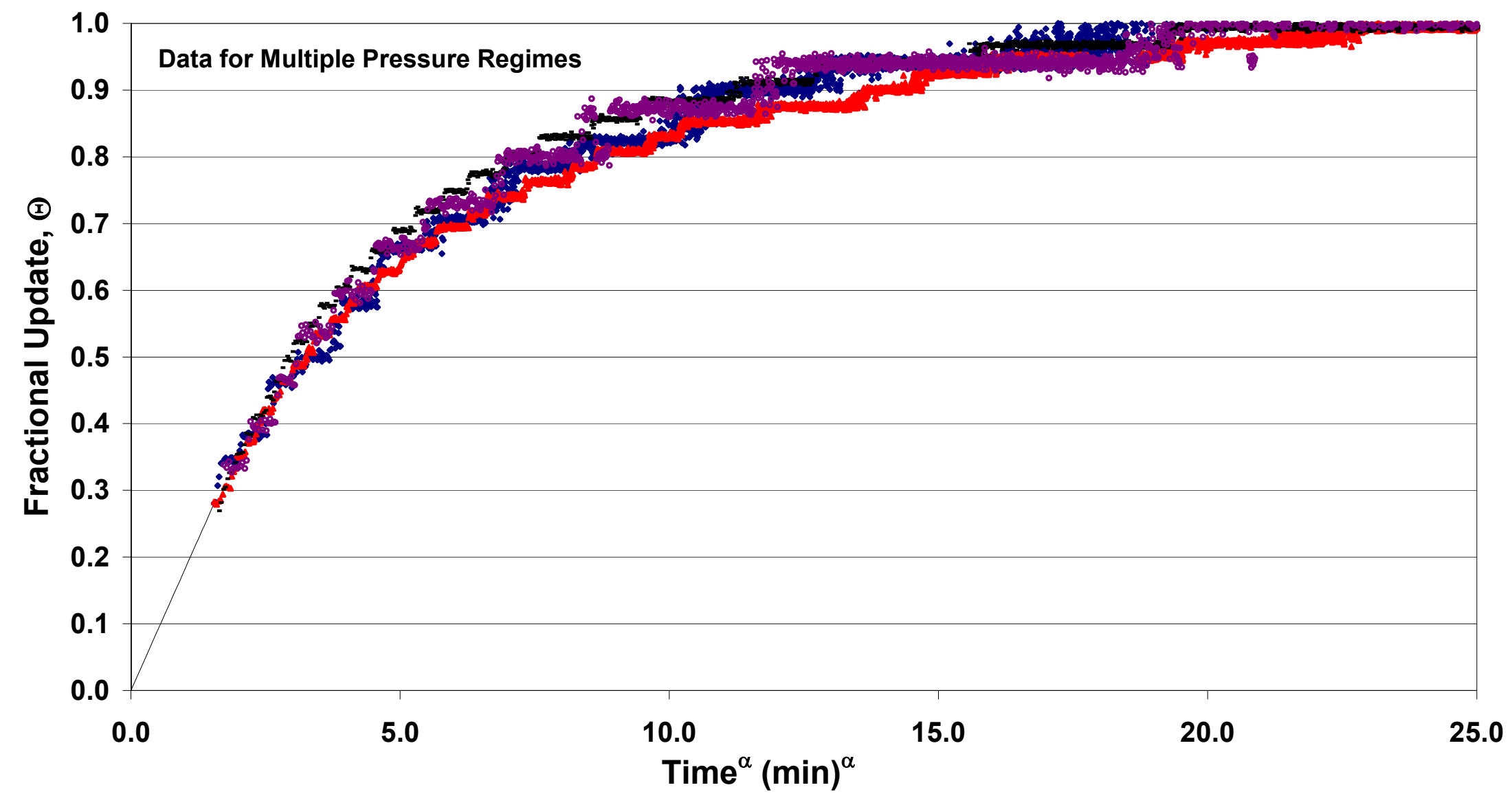


Figure 30. Adsorption Curve for $\mathrm{CO}_{2}$ on Tiffany Mixed Coal at $130{ }^{\circ} \mathrm{F}$

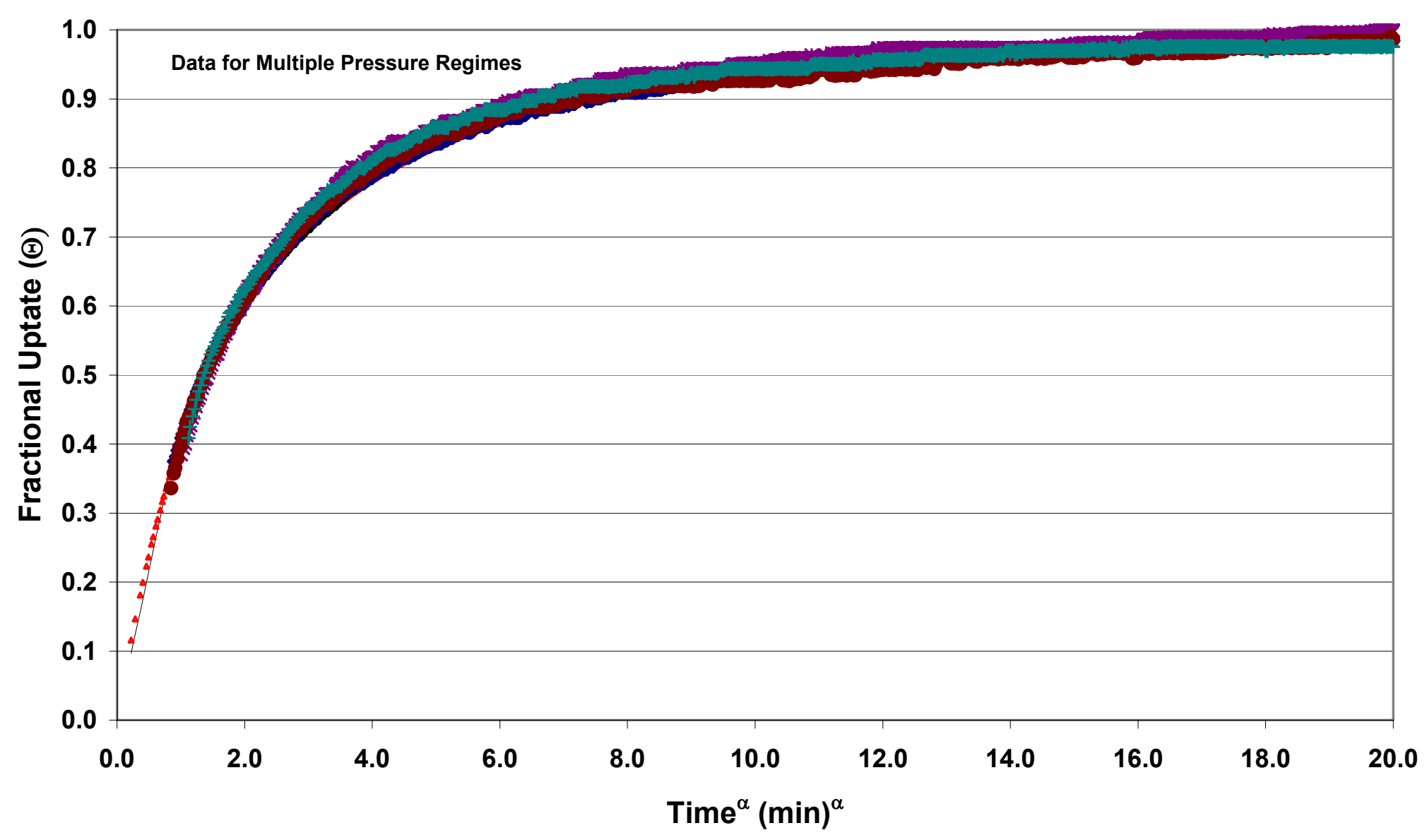


Figure 31. Liberated Gas from Tiffany Coal Samples:

2000 to 14.7 psia

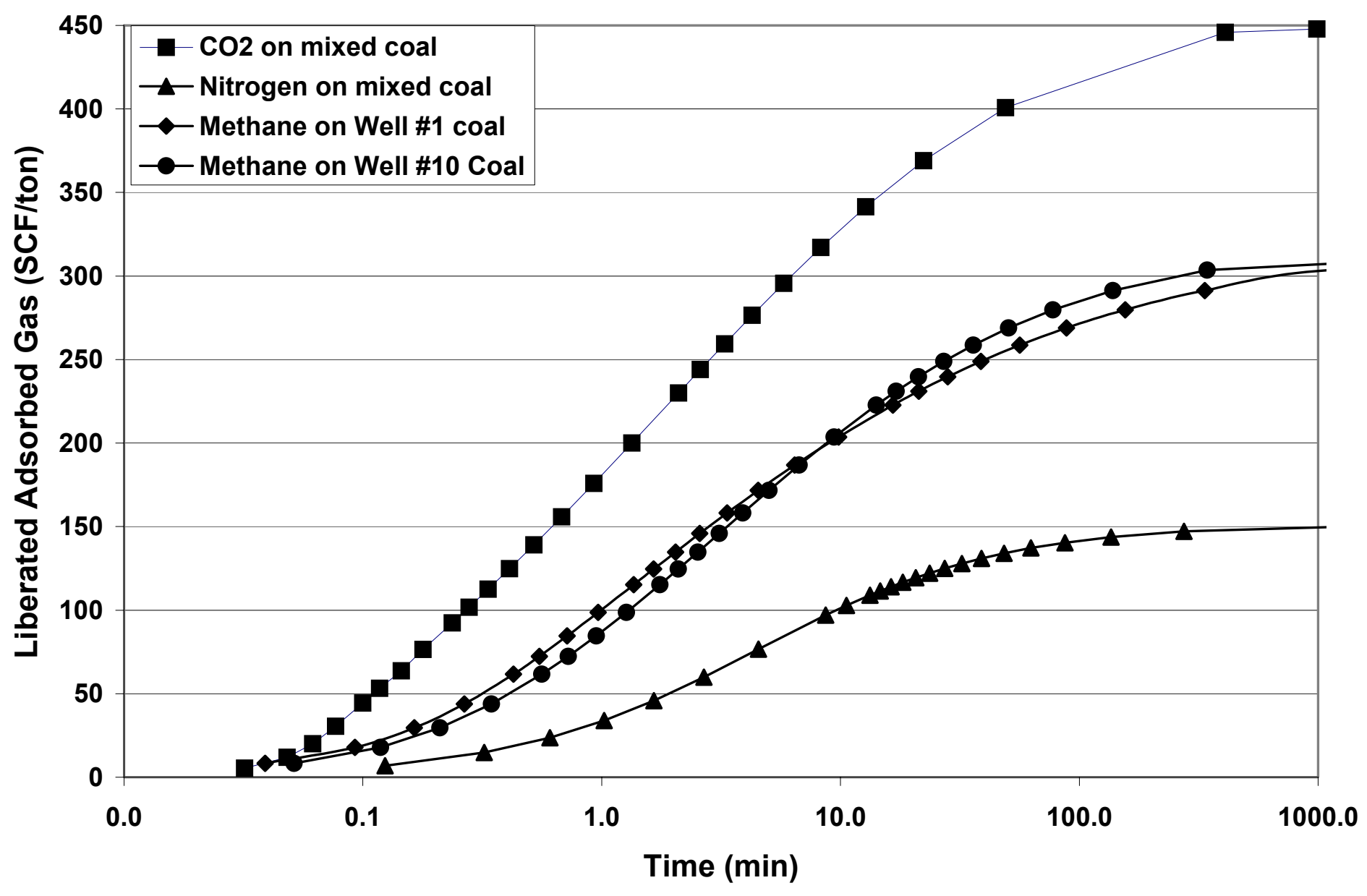

